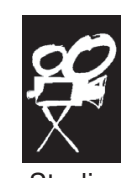

Studia

Filmoznawcze

37

Wrocław 2016

\author{
Łarysa Briuchowecka \\ Uniwersytet Narodowy „Akademia Kijowsko-Mohylańska”
}

\title{
POLSKA W KINIE UKRAIŃSKIM
}

\author{
DOI: $10.19195 / 0860-116 X .37 .6$
}

„Polska w kinie ukraińskim” to temat wymagający koncentracji i starannych poszukiwań materiału, zwłaszcza jeśli chodzi o filmy powstałe w okresie międzywojennym. Brak pełnego spectrum utrudniał analizy, wszak wiele filmów z lat 20. zostało zniszczonych i nie ma ich w archiwum filmowym Ukrainy.

Prócz tego istnieje jeszcze jedna przeszkoda. W filmach przedstawiano wydarzenia historyczne, które przez oba kraje - Ukrainę i Polskę — oceniane są zupełnie inaczej. Poprawność polityczna, tolerancja, znaczny dystans czasowy dzielący przedstawiane zdarzenia - wszystko to nie mogło ustrzec polskich krytyków od zarzutów występowania w filmach ukraińskich rzekomych nastrojów antypolskich, szczególnie w tych obrazach, które nie były akceptowane ze względu na wyraz artystyczny i styl reżysera. W rzeczywistości, gdy ukraiński reżyser kręci film, na przykład o Bohdanie Chmielnickim, zwracając się ku bolesnym i tragicznym kartom historii stosunków między oboma narodami, nie ma nic przeciwko Polsce - chce poznać i zrozumieć historię, zakazaną w czasach kolonialnego statusu Ukrainy. O skutkach tych zakazów Ołeksandr Dowżenko z bólem wyznał w swym Dzienniku: „Ukraińcy to jedyny naród na świecie, który nie zna swojej historii. Potwierdza to fakt, że największy ukraiński historyk, Mychajło Hruszewski, pisał wielotomową Historię Ukrainy-Rusi we Lwowie, mieście leżącym w granicach Austro-Węgier, ponieważ w Imperium Rosyjskim nie byłoby to możliwe. Stosunek do ukraińskich twórców z punktu widzenia zrozumienia takiej sytuacji, nie zaś podejrzeń o wrogie intencje, świadomość znaczenia, jakie dla Ukraińców ma poznanie przeszłości, usunie pretensje i pytania. Jedynie przepracowanie wspólnych traum historycznych umożliwi pojednanie niegdyś wrogo do siebie nastawionych narodów - oto cel niniejszego opracowania. Właśnie takie jest życzenie autorki niniejszego tekstu, a jeśli się ono spełni, będzie to największą 
nagrodą za wykonaną pracę. Zanim wyruszymy w podróż przez stulecie kina ukraińskiego, chciałabym prosić polskiego odbiorcę o nieosądzanie, jeśli w tej drodze jakiś wątek okaże się dla niego niezupełnie do przyjęcia.

\section{TEMAT POLSKI W KINIE UKRAIŃSKIEJ SRR LAT 20.}

Życie ówczesnej Polski w kinie lat 20. przedstawiono w filmach Cienie Belwederu i Za ściana. Działania militarne połączonych wojsk polskich i ukraińskich w wojnie z bolszewikami w 1920 roku i kampanię zimową z $1921^{1}$ roku pokazano natomiast w filmie $P K P$, walki Kozaków z wojskami Rzeczypospolitej — w filmie historycznym Taras Triasyło, hajdamaków zaś - w Ulewie. Zanim jednak przejdziemy do omówienia wymienionych filmów, wyjaśnijmy kilka ważnych dla naszego przeglądu kwestii.

Po pierwsze, czy filmy te posiadały „tożsamość narodową”? Nie do końca można nazwać je ukraińskimi, a to ze względu na sytuację polityczną Ukraińskiej Socjalistycznej Republiki Radzieckiej, która w 1922 roku dołączyła do „nierozerwalnego związku”, gdzie dominującym językiem, jak w czasach Imperium Rosyjskiego, był język rosyjski, a obowiązującą kulturą — kultura rosyjska. Jednak przez pierwsze siedem lat (od 1922 do 1929), by uspokoić nastroje narodowe, szczególnie inteligencji, rząd bolszewicki deklarował wagę kwestii narodowej, wspieranie języków i kultur narodowych. Uchwała partyjna z 1922 roku dała początek ukrainizacji, wprowadzając język ukraiński do szkół, uczelni wyższych, instytucji państwowych oraz w dziedzinie kultury.

Najwięcej problemów z ukrainizacją miało kino. W 1925 roku, wraz z rozpoczęciem intensywnego rozwoju produkcji filmowej w Odessie i Jałcie, w wywłaszczonych prywatnych wytwórniach filmowych Chanżonkowa, Jermoliewa i Charitonowa praktycznie nie było ukraińskiego personelu. Operatorów filmowych i scenografów ściągnięto z Niemiec, przed kamerami stanęli rosyjscy aktorzy (ci, którym nie udało się wyjechać), reżyserami także byli Rosjanie: Władimir Gardin, Piotr Czardynin, Nikołaj Sałtykow oraz zdemobilizowani z Armii Czerwonej bolszewicy - Gieorgij Tasin, Gieorgij Stabowyj, Arnold Kordium, scenarzystami Salomon Lazurin, Michaił Majski. Do pewnego stopnia problem ukraińskich kadr twórczych pomógł rozwiązać reformator teatru, założyciel i reżyser teatru „Berezil" — Łeś Kurbas (poświęcił filmowi pół roku swojego życia, kręcąc kilka filmów krótkometrażowych). Przyciągnął on do studia filmowego profesjonalnych i utalentowanych aktorów swojego teatru, którzy z łatwością dostosowali się do wymogów kina. Z teatru Kurbasa przybyli również reżyserzy. Scenarzystów wywodzących się ze środowiska pisarzy angażowali Michaił Semenko i Jurij Janowski. Działania ukrainizacyjne wspierał doświadczony Piotr Czardynin - autor filmu biograficznego Taras Szewczenko i pierwszego obrazu historycznego Taras Triasyto. Jednak

\footnotetext{
${ }^{1}$ W terminologii sowieckiej — „wojna radziecko-polska 1920 roku”, ,trzecia kampania Ententy”.
} 
bez pomocy znawcy sztuki ukraińskiej Wasyla Kryczewskiego i aktora Amwrozija Buczmy nie byłby w stanie tego dokonać. Powrotem do kina narodowego był film Ołeksandra Dowżenki Zwenigora, nakręcony w Wytwórni Filmowej w Odessie.

Odpowiedzi wymaga również pytanie, czy wspomniane filmy nieme miały wartość artystyczną. Jeśli podejdziemy do tej kwestii poważnie, odpowiedź będzie negatywna, tym bardziej że filmy te pełniły funkcje propagandowe. Wyjątkiem jest tu film Ołeksandra Dowżenki Zwenigora, który swą nowatorską formą i zaskakującą treścią przyciągnął uwagę środowiska literackiego, zyskując uznanie międzynarodowe. Faktem jest, że również i te niedoskonałe filmy współtworzą historię kina, mają wartość poznawczą (film jest sztuką zatrzymanego czasu, pozostawia po sobie świadectwo do pewnego stopnia obiektywne, co niekiedy stoi w sprzeczności nawet z wolą ich twórców, nie mówiąc już o zamiarach zleceniodawców).

Smutny jest fakt, że większość filmów VUFKU² zaginęła, gdyż w czasach represji były one niszczone, uznawane za „niewiarygodne”, a ich autorów nazywano „wrogami ludu" i represjonowano.

Ponieważ poglądy w obu naszych krajach dotyczące tych samych wydarzeń historycznych różnią się, niniejszym badaniom towarzyszyć musi odpowiednio zarysowany kontekst historyczny.

Jak zatem wyjaśnić obecność Polski w ukraińskiej kinematografii lat 20.? Tematem większości ówczesnych filmów były niedawne wydarzenia (wojna domowa), które na Ukrainie charakteryzowały się niezwykłą złożonością. Na terytorium Ukrainy walczyły ze sobą różne armie: bolszewicy (Armia Czerwona), białogwardziści (Denikin), wojska Ukraińskiej Republiki Ludowej (Petlura), Zachodnioukraińskiej Republiki Ludowej (Ukraińska Armia Halicka), anarchiści (oddziały Nestora Machny i innych atamanów), wojska niemiecko-austriackie oraz wojska polskie. W 1918 roku wojska niemieckie przebywały na Ukrainie na zaproszenie rządu URL, wykonując misję pokojową, białogwardziści walczyli z bolszewikami o władzę w Rosji i to właśnie te wydarzenia znalazły odzwierciedlenie w kinie rosyjskim, natomiast wrogami USRR były głównie wojska Petlury i Polacy.

Należy pamiętać, że władza bolszewicka, być może jako pierwsza na świecie tak energicznie i agresywnie, zaczęła propagować swe idee, czyniąc film narzędziem ideologii i propagandy. Wydarzenia przedstawiano nie tak, jak one przebiegały w rzeczywistości, lecz zgodnie z linią partii; przeszłość i czasy im współczesne pokazywano z punktu widzenia walki klasowej. Jednym z zadań kina było tworzenie wyraźnego obrazu wroga. Głównym zaś była Polska, która zbrojnie wystąpiła przeciwko bolszewikom i dlatego należało ukazywać ją w negatywnym świetle.

Aby uporządkować dość chaotyczny świat kina i zapobiec odejściu od wyznaczonej linii, sporządzono listę tematów priorytetowych. Znalazła się wśród nich

2 ВУФКУ (ukr. Всеукраїнське кінофотоуправління) — Ogólnoukraiński zarząd produkcji filmowej, działający w latach 1922-1930. Była to jednostka samodzielna, jedynie nominalnie podporządkowana Ludowemu Komisariatowi Oświaty USRR. 
rewolucja światowa. Na realizację tej idée fixe pracowały utworzone poza granicami ZSRR partie bolszewickie (później — komunistyczne), Międzynarodówka Komunistyczna i inne struktury. Kino wprowadzało tę ideę w filmach propagandowych i fabularnych poprzez dwa nurty: pierwszy — nacisk kładziono na zagraniczny proletariat, który zaczyna dojrzewać i walczyć ze swym wrogiem, burżuazją; drugi nurt ujawniał burżuazyjny wyzysk i rysował obraz jej nieuchronnej zagłady. W programie walki z burżuazją, w której światowy proletariat wkrótce ma zwyciężyć, co do czego żadnych wątpliwości nie mieli przywódcy bolszewiccy, znaczącą rolę odgrywała Polska, która nie poszła śladem bolszewików. Określali oni Polskę mianem „burżuazyjno-ziemiańskiej” lub „pańskiej”, armię URL zaś „,burżuazyjnymi nacjonalistami ukraińskimi”, „bezpośrednimi wspólnikami Białych Polaków”.

\section{NIECO FAKTÓW HISTORYCZNYCH}

Jeszcze 25 lat temu dotarcie do faktów z czasów walki Ukraińców o niepodległość w latach 1917-1920 było niezwykle trudne, tak szczelne były pokłady kłamstw, pomówień i obłudy. Przypomnimy je tu dzięki pracy i publikacjom historyków. By przejąć władzę na Ukrainie, bolszewicy zużyli mnóstwo arsenału, złożyli jeszcze więcej fałszywych obietnic, a sam proces trwał trzy lata. Być może nie doszłoby do tego, gdyby ukraińskie partie (przede wszystkim socjaldemokraci i partie właścicieli ziemskich) pragnące własnego państwa nie zwalczały się nawzajem. Pod koniec 1919 roku Armia Czerwona zajęła większość terytorium Ukrainy. Po wyczerpujących walkach z Denikinem i bolszewikami Główny Ataman armii URL ${ }^{3}$, Symon Petlura, starając się uniknąć ostatecznej porażki, zwrócił się o pomoc do marszałka Józefa Piłsudskiego. Oba kraje podpisują umowę warszawską, na mocy której terytorium Zachodniej Ukrainy ma wejść w skład RP. Przywódcy Zachodniej Ukrainy byli przeciwni tej decyzji, jednak Petlura nie widział innego wyjścia ${ }^{4}$. Połączone armie ukraińska i polska 7 maja 1920 roku zajęły Kijów. Dowódca Armii Czerwonej, Lew Trocki (właśc. Lejba Bronsztejn) w stylu agresywnej demagogii zareagował 8 maja: „(...) polski szlachcic wyłożył obie nogi na stole, przy którym zaledwie kilka dni temu zasiadali robotnicy i deputowani Armii Czerwonej"5, wyjaśniając, że ma na myśli Petlurę (,zz własnej woli sprzedał swoje usługi polskim ziemianom, jak wcześniej zaprzedał się niemieckiemu Kajzerowi i giełdzie angielsko-francuskiej. W ten sposób pod przykrywką Petlury polska szlachta miała okazję grabić Ukrainę”) i Piłsudskiego („Polscy właściciele ziemscy postanowili odzy-

3 Ukraińska Republika Ludowa.

${ }^{4} \mathrm{O}$ wydarzeniach tych opowiada polski film dokumentalny Trudne braterstwo (reż. J. Lubach, 1998 r.).

5 Л. Троцький, Київ у руках польських панів!, [w:] Украйнський Троцький, Одеса 2013, s. 79. 
skać swoje ziemie i cukrownie na Wołyniu, Podolu i Kijowszczyźnie ${ }^{6}$. Ich wierny sojusznik, szef państwa polskiego i głównodowodzący wojsk polskich Piłsudski odrzucił wszystkie propozycje pokojowe zaproponowane przez rząd radziecki”"7). Jednak połączone armie nie zdołały utrzymać stolicy — po miesiącu przyszło im opuścić Kijów i wycofać się aż do Lwowa i Warszawy. 17 sierpnia wojska polskie ponownie przeszły do ofensywy, radzieckie — zaczęły się cofać; 12 października Polska podpisała rozejm z Krajem Rad.

I wojna światowa zakończyła się, zaczął się ponowny podział terytoriów i każdy ze zwycięskich krajów europejskich chciał odnieść na tym korzyść. Interesy agresorów uczestniczących w wojnie, zwłaszcza Niemiec i Austrii, nie były brane pod uwagę. Pomimo poniesienia wielkich ofiar, stoczonych bitew i wysiłków dyplomatycznych, URL poniosła porażkę. Z tego względu, że bolszewicy ogłosili w Charkowie utworzenie USRR ${ }^{8}$, URL nie mogła figurować jako państwo niepodległe i w trakcie ponownego podziału terytoriów nikt nie brał jej pod uwagę. Tymczasem Polska, która przy wsparciu krajów Ententy wykazała aktywność w negocjacjach z bolszewicką Rosją, domagała się, by tereny Zachodniej Ukrainy pozostały w jej granicach. Innymi słowy, Polska zawładnęła częścią Ukrainy, jej samej nie ratując przed bolszewikami. Armia ukraińska znajdująca się teraz na terenie Polski na mocy traktatu ryskiego miała być poddana repatriacji, a Symon Petlura miał zostać wydany władzom bolszewickiej Rosji. Żołnierze wracali do domów, a ci, którzy nie chcieli żyć w kraju rządzonym przez bolszewików, udali się na Zachód. Pod koniec 1923 roku

Petlura został zmuszony do opuszczenia Polski, ratując się przed brakiem pieniędzy i niebezpieczną niestabilnością, nadzorem polskich i sowieckich agentów oraz swoim „odizolowaniem”. Była to ostatnia próba odnalezienia samego siebie. Petlura zrozumiał, że przetrwać na emigracji można jedynie działając na „,arenie międzynarodowej”, a „polskie odosobnienie” nie dawało takich możliwości. Miał on nadzieję stać się głosicielem idei „niepodległej Ukrainy”, koordynatorem działań ukraińskiej emigracji w Europie, przenieść do Europy Zachodniej ukraińskie emigracyjne Centrum Państwowe ${ }^{9}$.

Pokój ryski usankcjonował podział ziem ukraińskich i białoruskich między Polską a Rosją Radziecką. RFSRR i USRR zobowiązały się do zapewnienia Polakom mieszkającym na ich terytoriach pełnej wolności religijnej i kulturowej, a Polska gwarantowała takie same prawa dla swoich mniejszości narodowych: rosyjskiej, ukraińskiej i białoruskiej. Czy strony przestrzegały udzielonych gwarancji? Niestety, nie.

6 Właścicielem cukrowni na południu ówczesnej Kijowszczyzny był ojciec Trockiego.

7 Л. Троцький, За Радянську Украӥну! [w:] Український Троцький, s. 90. Warto zwrócić uwagę, że w recenzji antypolskiego filmu $P K P$, o którym dalej, tezy te są przytaczane dosłownie.

${ }^{8}$ USRR - Ukraińska Socjalistyczna Republika Radziecka.

9 В.А. Савченко, Симон Петлюра, Харьков 2006, Фолио, s. 391-392. 


\section{PROPAGANDA BOLSZEWIZMU W FILMIE}

Filmy agitacyjne to wynalazek bolszewicki, który miał podtrzymywać morale Armii Czerwonej w czasie przedłużającej się walki bolszewików ze społeczeństwem odrzucającym ich rządy oraz przekonać żołnierzy, że postępują właściwie. Jednym z takich filmików była Polska szlachta, wyprodukowana w Odessie w 1920 roku (scenariusz i reżyseria Nikołaj Sałtykow, film nie zachował się). Sądząc z nazwy, była to szybka reakcja na ofensywę wojsk polskich i URL.

Propaganda przybrała również formę przygodową. Przykładem jest film Niebieska paczka (scenariusz Geo Szkurupij i Wołodymyr Ihnatowycz, reżyseria Fawst Łopatynski, zdjęcia Oleksij Kalużny, scenografia Iwan Suworow. Obsada: Z. Pihulowycz, A. Symonow, S. Kryha, O. Merlatti. Film zaginą ${ }^{10}$ ), który wszedł na ekrany w 1926 roku i był debiutem kinowym Fawsta Łopatynskiego — reżysera wywodzącego się z teatru „Berezil”. Jest to jeden z pierwszych filmów pokazujących walki toczące się na Ukrainie. W miarę upływu lat ta militarystyczna tendencja zyskiwała na znaczeniu w kinie radzieckim. Po raz pierwszy w historii wojen nadarzyła się okazja, aby ponownie przeżyć działania zbrojne — tym razem przed kamerą i w bolszewickiej interpretacji. Chodziło o ofensywę wojsk polskich i armii URL.

Polacy zajmują jedno z ukraińskich miasteczek. Robotnicy z miasteczka organizują zbrojną reakcję przeciwko nim, jednak nie otrzymując wsparcia konnicy, która operowała na tyłach Polaków, ponoszą straszną porażkę. Mimo to gniew i entuzjazm robotników nie ustępuje. Organizują oddział partyzancki i rozpoczynają walkę od nowa ${ }^{11}$.

Film miał przekonywać, że siły bolszewików stale rosną. Informacji tej towarzyszą fotografie reżysera Fawsta Łopatynskiego, scenarzysty Geo Szkurupija, operatora Oleksija Kalużnego oraz kadr z filmu.

Fabuła skupia się na historii młodego chłopaka Petra, wysłanego z wiadomościami dla Czerwonej konnicy. W pogoń za nim rusza żołnierz Petlury. Petro ucieka, ale jego koń zostaje ranny, więc chłopak zajeżdża do znajomego chłopa. Ten daje mu świeżego konia, ale kradnie paczkę, by przekazać ją petlurowcom. Córka chłopa, Nadia, ukochana Petra, dowiedziawszy się, gdzie została ukryta paczka, wykrada ją i udaje się konno do siedziby powstańców. Po powrocie do powstańców Petro odkrywa, że paczka zniknęła. Decyzją komitetu rewolucyjnego, kierowanego przez ojca Petra, chłopca prowadzą na egzekucję, jednak w ostatniej chwili pojawia się Nadia z paczką. Oboje udowodnili swoje oddanie władzy bolszewickiej. Nawiasem mówiąc, to nie jedyny przypadek w ówczesnej kinematografii, gdzie „siłą napędową" fabuły jest tajemnicza paczka — wiele zdarzeń wokół tejże miało miejsce w filmie przygodowym Teczka kuriera dyplomatycznego Ołeksandra Dowżenki.

10 Informacje o filmach, które nie zachowały się, zaczerpnięto z publikacji z lat 20.

11 Д. Балик, Синій пакет, „Кіно” 1926, nr 5, s. 18. 
W następnym roku publiczność miała okazję zobaczyć na ekranie Sicz Zaporoską oraz bitwy Kozaków z wojskiem polskim. Film historyczny Taras Triasyło zdobył powszechne uznanie, również międzynarodowe. (Scenariusz napisał Wasyl Radysz na podstawie poematu Wołodymyra Sosiury; reżyseria: Petro Czardynin; zdjęcia: Borys Zaweliew, Oleksij Pankratiew; scenografia: Wasyl Kryczewski; obsada: Amwrosij Buczma, Iwan Zamyczkowski, Natalia Użwij, Iwan Kaprałow, Matwij Larow, Marharyta Barska, Mykoła Kuczynski. Wytwórnia Filmowa VUFKU w Odessie, 1927).

Jest to opowieść o Tarasie Fedorowyczu — zwanym przez lud Tarasem Triasyło — hetmanie Kozaków nierejestrowych z 1629 roku. Z jego nazwiskiem związane są pierwsze w historii Kozactwa uniwersały, skierowane do wszystkich, „którzy kiedykolwiek byli Kozakami lub chcą nimi zostać” z wezwaniem do walki ,za wiarę i dawne swobody" 12 . W marcu 1630 roku Fedorowycz stanął na czele powstania chłopsko-kozackiego skierowanego przeciwko Polsce. Wojsko polskie odcięło Kozaków na lewym brzegu Dniepru aż do Perejasławia. Z nadejściem głównej armii walki stawały się coraz bardziej zacięte i trwały niemal trzy tygodnie. Polakom nie udało się jednak zdobyć obozu kozackiego. Z inicjatywy starszyzny rozpoczęły się rozmowy pokojowe. Podpisano ugodę perejasławską. Koniecpolski ogłosił amnestię dla uczestników powstania i zwiększył rejestr wojsk kozackich do ośmiu tysięcy ${ }^{13}$.

Ponieważ filmu tego nie ma w Archiwum Filmowym Ukrainy, do jego opisu wykorzystamy źródła pisane. Informacja o tym, że Czardynin w Wytwórni Filmowej w Odessie kończy kręcić wielkie widowisko historyczne Taras Triasyło (Ukraina, XVII wiek) ukazała się w czasopiśmie „Kino” w październiku 1926 roku. Już w grudniu film został ukończony.

Zamieszki społeczne, najazdy tatarskie, samowola panów, wolna Sicz Zaporoska - oto tematyka filmu. Taras Triasyło to zwykły chłop, który, nie mogąc znieść samowoli panów, ucieka na Sicz, gdzie zyskuje sławę buntownika i powstańca walczącego przeciwko szlachcie nękającej Ukrainę $e^{14}$.

W filmie nacisk położono przede wszystkim na wyeksponowanie krzywdy, którą polscy panowie zadają ukraińskim chłopom, na walkę Tarasa, który poprzysiągł pomścić uciśnionych. Staje on na czele oddziału kozackiego, odnosi zwycięstwa w bitwach z Tatarami i Turkami. Sprzeciwia się niezdecydowaniu hetmana, który znalazł wspólny język ze szlachtą, podnosi bunt, ale w końcu umiera. Sceny walk z Polakami nakręcono z wielkim rozmachem.

Podstawą filmu stał się poemat Wołodymyra Sosiury Taras Triasyło, w którym wydarzenia historyczne przeplatają się z fikcją, a bohatera nieco uwspółcześniono.

12 Н. Яковенко, Нарис історії середньовічної та ранньомодерної Украӥни, Київ 2006, s. 280. Chodzi o rejestr wojska kozackiego uznanego przez władze Rzeczypospolitej.

13 Ibidem.

14 „Кіно” nr 12, грудень 1926, s. 2-3. 
W utworze Sosiury były i bitwy, i historie miłosne, echa powieści pseudohistorycznych; był liryczny nastrój, uwydatniono sympatię dla bohaterów, ukazano problemy klasowe. Scenarzysta Wasyl Radysz, zachowując liryzm poematu i logicznie motywując fabułę, redukując niektóre wątki miłosne, nakręcił film historycznie wiarygodny. Już w pierwszej z ośmiu scen scenarzysta motywuje ucieczkę Tarasa na Sicz tym, że buntuje się on przeciwko pańskiej rozpuście, wstawia się za siostrą (z adnotacji do filmu: „Syn polskiego magnata zgwałcił siostrę Tarasa Triasyło”) ${ }^{15}$. Sceny na Siczy Zaporoskiej, na polach bitew, nakręcono z dużym znawstwem. Wpływ słynnego obrazu Riepina Kozacy pisza list do tureckiego sultana był zauważalny zarówno w kompozycji odpowiednich scen, jak i w doborze obsady ${ }^{16}$. Polskiego magnata zagrał Matwij Larow — jeden z najpopularniejszych aktorów ukraińskiego filmu niemego.

Film zawdzięczał swój sukces historycznym dekoracjom i kostiumom scenografa Wasyla Kryczewskiego, które odzwierciedlały epokę w najmniejszych detalach. Na terenie studia filmowego w Odessie zbudował on wspaniałe dekoracje Siczy Zaporoskiej, z niezwykłą starannością odtworzono całe ulice z kureniami, chatami i cerkwiami.

Po raz pierwszy za czasów sowieckich film zapoznawał ukraińskiego widza $\mathrm{z}$ jego historią. Obraz był wyświetlany w sowieckim przedstawicielstwie handlowym w Pradze pod tytułem Bohater wolności.

Francuski miesięcznik filmowy „Cineopse” określił film Taras Triasyło freskiem historycznym, podkreślił dobrą grę aktorów, którzy wiernie oddali nastroje ludu podczas powstania Ukrainy przeciwko polskiemu uciskowi w XVII wieku, a także zdjęcia pięknych krajobrazów i rozmach realizacji filmu" 17 .

Jednak po sześciu latach zaczęły się prześladowania wszystkiego, co choć trochę świadczyło o ukraińskości, o historii Ukrainy. Film zdjęto z ekranów jako kontrrewolucyjny. W 1933 roku oficjalna krytyka oskarżyła go o obecność „elementów petlurowskich", a także o to, że powstał w oparciu o nacjonalistyczną historiografię. Obraz poddano ponownemu montażowi, w 1937 roku udźwiękowiono i nadano mu inny tytuł (Opowieść o cieptym sercu). Być może Taras Triasyło przechowywany jest za granicą, bo w drugiej połowie lat 20. filmy VUFKU kupowano na rynkach zagranicznych. Informacje na ten temat podaje Lubomyr Hosejko:

Jak większość obrazów okresu filmu niemego, Taras Triasyło Czardynina nie trafił do współczesnego odbiorcy i do niedawna był uważany za zaginiony. Ale od czasu do czasu był wyświetlany przez filmotekę francuską pod tytułem Tatarzy. Fakt ten wzmacnia ideę o hipotetycznym przechowywaniu w zagranicznych archiwach filmowych obrazów produkcji VUFKU ${ }^{18}$.

15 Анотований каталог фільмів, вироблених на Одеській кіностудії художніх фільмів, Одеса 2004, s. 83.

16 О. Бабишкін, Украӥнська література на екрані, Київ 1966.

17 Сінеопс про „Тараса Трясила”, „Кіно” 1929, nr 23-24, s. 10.

18 Л. Госейко, Історія украӥнського кінематографа 1896-1995, przekł. z fr., Київ 2005, s. 32 . 
Próbą pokazania życia w ówczesnej Polsce był film Cienie Belwederu (scenariusz A. Zorin; reżyseria Ołeksandr Anoszczenko; zdjęcia W. Lemke. Obsada: Amwrosij Buczma, M. Dusimetiere, Polina Skliar-Otawa, Kostiantyn Koszewski. Wytwórnia Filmowa VUFKU w Jałcie, 1927). W prasie pisano:

Fabuła filmu: nowa Polska trawiona przez stare bolączki społeczne i narodowe. Nad nową Polską rozpościerają się ciemne „,cienie Belwederu”, tłumiąc wszelkie życie, wszystko, co zdrowe. Bohater zdąża do nowej Polski, ale... jej nie ma. Jest za to Polska pełna starych zabobonów, Polska ucisku i biedy. Jednak kraj stoi u progu wiosny. To, co stare, przeminie, a nad Polską zatrzepocze czerwony sztandar. Film reżyserował O.D. Anoszczenko, twórca Tragedii trypolskiej. Zdjęcia - W. P. Lemke ${ }^{19}$.

Warszawę „kręcono” prawdopodobnie w Odessie. Magazyn „Kino” zamieścił kilka zdjęć: „Obok warszawskiej synagogi”, „W więzieniu”, „Spotkanie polskiej loży masońskiej”, „Kapral Zwoliński i Lia, hrabia”. Była to przeciętna produkcja, z grą aktorską daleką od prawdy życiowej, być może z wyjątkiem gry doświadczonego Nikołaja Panowa, który satyrycznie ubarwił postać polskiego ministra spraw wewnętrznych Czekorskiego. Historia kina radzieckiego krytycznie oceniła film: „Intryga jest wymyślona, w melodramatycznych perypetiach w dużej mierze utonęły rzeczywiste wydarzenia walki klasowej w burżuazyjnej Polsce" ${ }^{20}$. Filmowi wytykano nadmierne nagromadzenie sytuacji z gatunku awanturniczych. Już później radzieccy historycy kina zarzucali filmom $z$ lat 20. to, że niwelowano w nich klasowy charakter bohaterów. Oczywiście, ukraińscy filmowcy, którzy zwracali się ku obcemu materiałowi (w następnej dekadzie będzie to niemożliwe - zgodnie z nakazem władz moskiewskich kulturę ukraińską obniżono do poziomu prowincjonalnej), chcieli przyciągnąć widza, stąd też sceny awanturnicze. Chęć przedstawienia w Cieniach Belwederu rzeczywistości ówczesnej Polski, bez posiadania podstawowej wiedzy na jej temat, doprowadziła do porażki - wydarzenia i postacie nie były przekonujące.

Kluczowym utworem o Polsce i Ukrainie jest film PKP (Pitsudski kupit Petlurę - scenariusz Gieorgij Stabowyj, Ołeksandr Lifshitz, reżyseria Aksel Lundin, Gieorgij Stabowyj, zdjęcia Marius Holdt, F. Verigo-Darowski, Josip Hudym, Grigorij Drobin, scenografia Salomon Zarycki, S. Chudiakow. Obsada: Mykoła Kuczynski (Symon Petlura), Matwij Larow (Józef Piłsudski), Iwan Kaprałow, Mykoła Nademski, S. Szklarewski, Natalia Użwij, Dmytro Erdman, Wasyl Ludwynski. Wytwórnia Filmowa VUFKU w Odessie, 1926). Film oparto na kanwie rzeczywistych wydarzeń (umowa warszawska, którą Petlura podpisał z Piłsudskim 22 kwietnia 1920 roku, wycofanie obu armii z Kijowa i kampania zimowa 1921 roku). Zawarcie umowy nie przyszło łatwo Głównemu Atamanowi: 3 kwietnia Polacy przedstawili Petlurze projekt i zażądali odpowiedzi w ciągu czterech dni. Projekt, a w szczególności punkt dotyczący ustanowienia nowych granic, oburzył Petlurę. Podczas

19 М. Платонов, На Ялтинській фабриці, „Кіно” 1926, nr 6-7, s. 19.

20 История советского кино, t. 1. 1917-1931, Москва 1969, s. 589. 
spotkania z Petlurą Piłsudski obiecał pójść na pewne ustępstwa w kwestii granic. 10 kwietnia odbyła się konferencja, podczas której strona polska zgodziła się przesunąc granicę do linii Zdołbunów-Równe-Radziwiłłów. 21 kwietnia doszło do nowego spotkania w Belwederze; Petlura, bez świadków, rozmawiał z Piłsudskim przez ponad pięć godzin. Decyzja została podjęta. Podpisaniu kolejnych dokumentów towarzyszyło porozumienie w sprawie zachowania pełnej tajemnicy. Kierownictwo URL zgodziło się na to, by w granicach Polski pozostała Galicja i zachodni Wołyń z 11 milionami mieszkańców, z czego 7 milionów stanowili Ukraińcy. Najbardziej bolesna była kwestia tych powiatów, w których etniczni Polacy stanowili 4-10\% ludności. Petlura uzasadniał zawarcie umowy beznadziejną sytuacją URL, brakiem jakichkolwiek środków materialnych, armii i terytorium, a później uznał ją za akt zbawienny do kontynuowania walki.

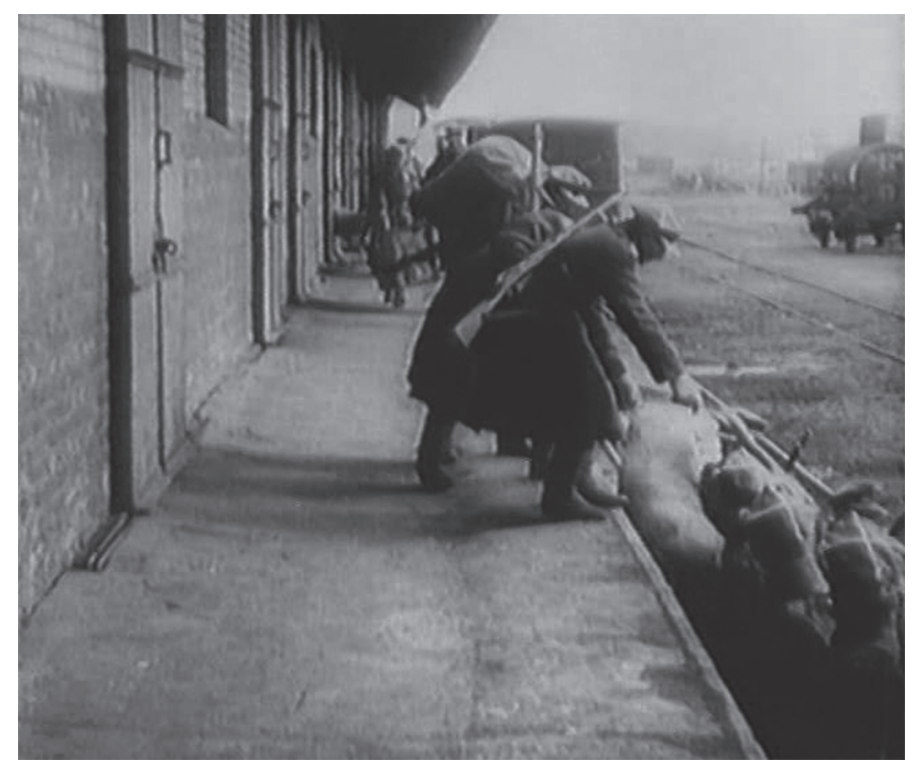

1. Polskie wojsko w maju 1920 roku wywozi żywność z Ukrainy. Kadr z filmu $P K P$

Co spowodowało zainteresowanie filmowców tym, bodaj czy nie najbardziej dramatycznym epizodem walk z lat 1917-1921? Po pierwsze, bolszewików irytował nie tylko fakt ukraińskiego oporu, ale pojawienie się ich polskiego sojusznika. Po drugie, bolszewicy obawiali się tego, że marszałek Piłsudski, który w maju 1926 roku ponownie doszedł w Polsce do władzy, będzie wspierać Petlurę — sojusznika w wojnie z bolszewikami. Tak więc wydaje się, że nieprzypadkowo w maju tego roku w Paryżu bolszewicki agent Schwartzbard w biały dzień zabija Petlurę, wyjaśniając później w sądzie, że strzelał, by pomścić pogromy Żydów. W rzeczywistości Petlura był zdecydowanym przeciwnikiem pogromów i surowo karał winnych. Na 
wieść o zabójstwie Petlury akademik Serhij Jefremow w swym Dzienniku, pod datą 26 maja 1926 dokonuje wpisu:

Tylko bolszewikom mógł przeszkadzać posiadacz jedynego tak popularnego na Ukrainie i niesplamionego zdradą nazwiska. Nawet teraz, gdy nie miał żadnej realnej władzy, sam cień tego imienia groźnie przeciwstawiał się bolszewikom ${ }^{21}$.

Petlurę (a później Konowalca i Banderę) zlikwidował agent NKWD ${ }^{22}$, a bolszewickie służby likwidowały innych znanych Ukraińców. Po śmierci Petlury bolszewicy zaczęli go oczerniać, pokazywać według wspomnianego schematu nakreślonego w 1920 roku przez „stratega” Lwa Trockiego. Rozpoczęła się kampania oczerniania, maszyna propagandowa obrzucała błotem przywódców walk o niepodległość Ukrainy, a słowo „petlurowiec”, jak później „banderowiec”, stało się etykietą, która oznaczała dla człowieka wyrok. Film PKP to pierwszy akt propagandy, polegający na stworzeniu etykiety pod nazwą ,petlurowszczyzna"23. Jednak obśmianie „zaprzedańca” nie wystarczyło, autorzy PKP podnieśli rękę również na jego sojuszników, a film skierowano przeciwko Polsce - wyobrażenia autorów na jej temat pokazano w nie mniej niż ośmiu scenach.

Prace nad filmem rozpoczęły się w listopadzie 1925 roku, a na zdjęciach z filmu opublikowanych w czasopiśmie „Kino”, znaleźli się aktorzy odtwarzający role Piłsudskiego i Petlury. Pierwotnie film reżyserował Aksel Lundin, operatorem był F. Verigo-Darowski. Kiedy reżyser zachorował, VUFKU zaprosiło do współpracy Muhsin Beja z Turcji. Najprawdopodobniej współpraca nie układała się, jak należy, więc film ukończył Gieorgij Stabowy ${ }^{24}$.

„Kino” opublikowało duży artykuł P.K.P. podpisany nazwiskiem W. Setar (oczywiście był to pseudonim). Jego komentarz był wykazem zarzutów wobec Petlury i wyrazem nienawiści do Piłsudskiego. Umowę warszawską autor interpretuje jako „zaprzedaństwo Petlury”. Polska obwiniana jest o nieprzestrzeganie warunków traktatu ryskiego, uzgodnionych między Polską a ZSRR.

Wydarzenia mają rzeczywiście miejsce jak w kinie. W Rydze podpisano traktat pokojowy pomiędzy Polską i państwami radzieckimi. Traktat zawiera porozumienie, na mocy którego Polska zobowiązuje się do tego, by nie utrzymywać na jej terytorium Petlury, jego ministrów i niedobitków wojska. Umowę podpisano uroczyście, dano szlacheckie „słowo honoru”. Warunki traktatu są wypełniane specyficznie: petlurowcy zdejmują szyldy ze swych instytucji „państwowych", a Petlura zleca Tiutiunnykowi niszczenie Ukrainy radzieckiej. To dwa różne typy ludzi. Nienawidzą się, ale pracują razem, bo wspólne przestępstwo, „pakt” z Polską, łączy ich (...) Ślą

21 С. Сфремов, Щоденники. 1923-1929, Київ 1997, s. 378.

22 Ludowy Komisariat Spraw Wewnętrznych ZSRR.

23 To dość przykre, ale do zdemaskowania Symona Petlury przyczynił się również Ołeksandr Dowżenko w filmie Szczors, ukazując krótką scenę posiedzenia Dyrektoriatu, jego bezradność wobec ofensywy Mykoły Szczorsa na Kijów.

24 W filmografii z 1970 r. napisano: autorzy scenariusza G. Stabowy, O. Lifshitz, reżyserzy A. Lundin, G. Stabowy, zdjęcia M. Holdt, F. Verigo-Darowski, G. Drobin. 
do Warszawy notę dyplomatyczną, wskazując na fakty świadczące o udziale polskiego rządu w działaniach antyradzieckich. Polska dyplomacja ma oryginalne zadanie: uparcie zaprzecza oczywistym faktom. Chroni prace Sztabu Generalnego, Petlury i jego agentów. Nieuchronnie zbliża się krwawy dramat ${ }^{25}$.

Jaki to film? Pod względem treści i formy to agitka skrojona sztampowo w celu oczernienia i wyszydzenia przeciwników politycznych. Akcja rozgrywa się jednocześnie w Warszawie i Kijowie (Warszawę „kręcono” w pawilonach Wytwórni Filmowej w Odessie, tam też zbudowano wnętrze kijowskiego soboru św. Zofii — właśnie tam spotykają się „spiskowcy” przygotowujący powstanie przeciwko bolszewikom). Przedstawiono ich w filmie jako ludzi tępych i krótkowzrocznych; wpuszczają do swego kręgu agenta Czeka, uważając, że w jego żyłach płynie „kozacka krew”. Ten milczy i myśli sobie: „Mylisz się, nie kozacka, lecz proletariacka”.

PKP to skrót widniejący na polskich wagonach kolejowych („Polskie Koleje Państwowe”). Na początku filmu do wagonów PKP ładowane są worki, wanny, oto Polacy okradają Ukrainę. Człowiek z chytrym uśmiechem i zmrużonymi oczyma (aktor Mykoła Nademski w tej epizodycznej scenie przypomina podpitego rosyjskiego chłopa) rozszyfrowuje napis PKP: „Piłsudski kupił Petlurę”. Odescy żartownisie przeinaczyli tę nazwę na „KPP” — „Kiedy przestaną pić?”. Zewnętrzne podobieństwo aktora grającego Petlurę nie ratuje tej postaci, choć na tle innych wyraźnie się wyróżnia. W „polskich” epizodach uwydatniono zwierzchni i pogardliwy stosunek Polaków do Ukraińców, którzy znaleźli się w Polsce. Ukraińców przedstawiono karykaturalnie. To wrażenie wzmacniane jest poprzez zły makijaż, niechlujny wygląd aktorów - zwłaszcza tych, którzy grali „wrogich” względem władz bolszewickich Ukraińców i Polaków, np. żołnierze URL maszerujący po małym placu w podartych ubraniach to głupki; choć w innych scenach, już podczas walk prezentują odwagę i mistrzostwo jazdy konnej. Jednak na takie rozbieżności autorzy nie zwracają uwagi. Dla odmiany wojsko polskie ubrane jest w wysokiej jakości nowe mundury.

Petlura wydaje dyspozycję, by w Warszawie utworzyć podziemny sztab powstańczy, na którego czele staje Jurij Tiutiunnyk. Sztab ma siedzibę w jednym pomieszczeniu z ekspozyturą, a ukraińskim oficerom wydawane są „różowe papiery”, czyli dokumenty polskich szpiegów. Upokorzenie Petlury wzmacnia również jego otoczenie (w napisach nazwane ,jego poplecznikami”), m.in. Nakoneczny (Dnister) — szef ukraińskiego podziemia. Aby podkreślić, jakim był pośmiewiskiem, nakręcono scenę zbiorową w ,amerykańskim barze”. Nakoneczny siada na wysokim barowym stołku i upija się winem. Aktor gra pijanego bardzo wiarygodnie: trudno mu zejść z wysokiego krzesła, wymiotuje, nie może trafić do toalety — w przebitkach montażowych pokazano rozbawioną publiczność. Przy wtórze śmiechu ochoczych do rozrywki kobiet polski porucznik Kowalewski, komisarz wspomnianego pod-

25 „Кіно” 1926, nr 8, s. 16-17. 
ziemnego sztabu powstańców, zawiadamia ich: „Uwaga, oto szef ukraińskiego podziemia". Podaje Nakonecznemu kieliszek wina, a ten zacinając się, bełkocze, że więcej nie może. Porucznik ze złośliwym uśmieszkiem zwraca się do kobiet: „Tak, on naprawdę już więcej nie może". Nie znając się na naturze dowcipu, autorzy proponują śmiech z czynności fizjologicznych.

$P K P$ nie wart byłby uwagi, gdyby nie sceny bitew. To trudny pod względem realizacji, dwuczęściowy film, w którym sceny batalistyczne kręcono metodą rekonstrukcji. W stylu dokumentalnym nakręcono bitwy wojny polsko-bolszewickiej 1920 roku w miejscach, w których się one toczyły (wydarzenia miały miejsce latem, jednak żołnierze nie są ubrani w letnie mundury). Sceny kręcono z rozmachem, zwłaszcza bitwy z udziałem konnicy, w tym te z drugiej kampanii zimowej. Na jej czele staje Jurij Tiutiunnyk chcący wzniecić zbrojne powstanie na Ukrainie, jednak ponosi klęskę. Na ekranie widać, że żołnierze nie odpoczęli od ostatnich walk. Oryginalność filmu przejawia się w tym, że uczestnik wydarzeń sprzed pięciu lat generał-chorąży armii URL Jurij Tiutiunnyk (ówczesny redaktor VUFKU) — zagrał samego siebie; tak więc mamy okazję zobaczyć niezwykłą postać uwiecznioną na taśmie filmowej (w 1929 roku aresztowano go, rok później rozstrzelano i surowo zabroniono przywoływać jego nazwisko). Samego siebie miał zagrać również dowódca bolszewicki Grigorij Kotowski — prawdziwy przeciwnik Tiutiunnyka w kampanii zimowej, ale zamysł się nie powiódł: 6 sierpnia 1925, na dzień przed rozpoczęciem zdjęć, Kotowski zginął w rejonie Odessy ${ }^{26}$. Szkoda, że Tiutiunnyk zgodził się na udział w propagandzie bolszewizmu, jednak jego los leżał w rękach bolszewików (czekiści podstępem zwabili go z Polski na Ukrainę) ${ }^{27}$. Jego obecność ma również pozytywną stronę: jako człowiek i postać z filmu ujawnia fałsz bolszewickiej karykatury. Wśród tego fałszu Jurija Tiutiunnyka pozytywnie wyróżnia dobry wygląd, naturalne zachowanie, poczucie godności.

W dobrym tonie filmów niemych była mała ilość napisów objaśniających wydarzenia rozgrywające się na ekranie. $P K P$ jest nimi przesycony - mają one rekompensować niewiarygodność wydarzeń. W słowach nie ma cienia wielkoduszności — obecna jest jedynie nienawiść do pokonanych przeciwników. Wypowiedzi bohaterów i komentarze autorskie przypominają język świata przestępczego. Można odnieść wrażenie, że film został zakazany również ze względu na ubogi poziom propagandy bolszewickiej, która jest bardzo niskich lotów, np. „Petlurowskie podziemie kontynuowało swą gnuśną robotę”, „Ci ludzie są jak robaki” (o spiskowcach), „Zgraja drapieżników dzieliła łup” (o Petlurze i jego współpracownikach),

${ }^{26}$ Film kręcono niby zgodnie z dokumentacją, a w scenie ataku w czerwcu 1920 r. Armią Czerwoną dowodzi Grigorij Kotowski. W rzeczywistości Kotowski likwidował uczestników kampanii zimowej, a w walce odznaczyła się przede wszystkim 1 konna armia Siemiona Budionnego.

27 Я. Файзулін, Знаряддя провокаиії, „Український тиждень” $\mathrm{nr} 40$ (30 вересня-6 жовтня 2011), s. 47-49. 
„Oni tak zwiewają, że ducha zaraz wyzioną”. Retoryka względem bolszewików była inna: „Jak burza popędzili bohaterscy kotowcy”.

Film, choć był brutalnym zamysłem bolszewików, mającym na celu dyskredytację Józefa Piłsudskiego i Symona Petlury, nie miał szczęścia. W czasach stalinowskiego terroru najpierw poddano go ponownemu montażowi, skracając do ośmiu epizodów, a ostatecznie zakazano, nie pozostawiając nawet kopii (przemontowaną wersję filmu udało mi się przejrzeć dzięki Lubomyrowi Hosejce — kopia zachowała się we Francji).

$\mathrm{W}$ przeciwieństwie do nakręconej $\mathrm{z}$ rozmachem produkcji Aksela Lundina i Heorhija Stabowego film Za ściana według opowiadania polskiego pisarza G. Daniłowskiego ${ }^{28}$ ma zupełnie inny, kameralny charakter (poprzednie nazwy: Język ścian, Kim ona jest?, Nieudana powieść; scenariusz L. Powołocki i Amwrosij Buczma, reżyseria Amwrosij Buczma, zdjęcia A. Stanke, scenografia Heinrich Beisenherz, Iwan Suworow. Obsada: Amwrosij Buczma (Janusz Torczyński), Polina Skliar-Otawa (Klara), M. Dusimetiere (przyjaciółka Klary), Kostiantyn Koszewski (przewodniczący, sekretarz, członek sądu, prokurator i obrońca). Wytwórnia Filmowa VUFKU w Odessie, 1928; film nie zachował się). Tematem przewodnim filmu jest polska inteligencja. To jedyny obraz wyreżyserowany przez aktora Amwrosija Buczmę, który był wówczas czołowym aktorem filmowym, odtwórcą głównych ról w znaczących filmach Taras Szewczenko i Taras Triasyło. Według autora monografii Амвросій Бучма в кіно Olega Babyszkina

Buczma znał życie polskiej inteligencji, której we Lwowie było dużo, widział również niektórych byłych polskich rewolucjonistów, wiedział, jak się zachowują (...). Dlatego chciał pokazać degradację słabych duchem ${ }^{29}$.

Film nie jest podobny do obrazów, które przeważnie produkowała wytwórnia: nie jest to ani rewolucyjny film akcji, ani film przygodowy, lecz dramat psychologiczny. Jeśli wierzyć opisowi fabuły filmu, ukazuje on ludzi, którzy nie są zdolni do podejmowania decyzji, do jakichkolwiek działań. Można przypuszczać, że w kręgu zainteresowań reżysera i aktora znajdują się głównie ludzie i ich uczucia, nie ma szczególnego znaczenia to, czy są to rewolucjoniści czy też nie. Dla Buczmy, który naoglądał się fanatyzmu rewolucyjnego, ważne było to, że „nie samą rewolucją...” Najlepiej jednak oddać mu głos: oto opowieść, którą pod koniec 1927 roku nagrał współpracownik magazynu „Kino”:

W polskim więzieniu przebywa Janusz Torczyński, więzień polityczny. Przez osiemnaście miesięcy chodzi z kąta w kąt po dwumetrowej celi.

Pewnego dnia w sąsiedniej celi pojawia się kobieta, inteligentka, rewolucjonistka Klara. Ucieszył się niewolnik kapitalistów, rzucił się do ściany, stuka w nią łyżką. Usłyszawszy odpowiedź, po raz pierwszy od półtora roku uśmiecha się.

28 W Anotowanym katalogu filmów wyprodukowanych w Wytwórni Filmowej w Odessie nazwisko to brzmi Danylewski (ukr. Г. Данилевський).

29 О. Бабишкін, Амвросій Бучма в кіно, Київ 1966, s. 58. 
Postukiwanie w ścianę obojga bohaterów trwa. Nie widząc się nawzajem, młodzi zakochują się w sobie. Po jakimś czasie Klarę zwolniono. Pewnej ciemnej nocy Januszowi udaje się zbiec.

Byłych więźniów ponownie łączy przypadek. Klara milczy, zamiast przyznać, że to ona, jego sąsiadka z więzienia, która go zna i kocha. Dusi w sobie chęć wyznania Januszowi prawdy. Mało tego, śledzi go, jest o niego zazdrosna...

Praca polityczna i propagandowa (rzecz dzieje się w burżuazyjnej Polsce) odsuwa się na dalszy plan. Zamiast tego, by zaspokoić swoje uczucia i nastroje, bohaterowie zabijają w sobie ludzką godność. Istnieje jedynie własne ,ja”. Chwiejni to ludzie, ci rewolucjoniści-inteligenci. Dość łatwo odchodzą od swoich przekonań.

Więźniowie są bardzo pasywni i zamknięci w sobie... Nie dbają o to, co dzieje się poza sferą ich własnych spraw ${ }^{30}$.

Postać Janusza jest zupełnie inna od poprzednich ról Amwrosija Buczmy, ale właśnie to go w niej przyciągało. Buczma był przekonany, że

prawdziwy aktor powinien stworzyć wyrazisty charakter, często wręcz przeciwny jego wnętrzu, powinien być w stanie wznieść się do poziomu charakteru tworzonej postaci. W miarę swych fizycznych warunków i możliwości aktor powinien umieć zagrać wszystko ${ }^{31}$.

\section{POZA GRANICAMI PROPAGANDY. FILM JAKO MYŚLENIE OBRAZEM}

Ołeksandr Dowżenko, twórca o filozoficznym podejściu do rzeczywistości, chciał pokazać w filmie historyczny przełom, nieuniknione zmiany zachodzące na Ukrainie, ukazać je w kontekście historii dawnej i nowszej. Dzięki specyficznemu scenariuszowi Dowżenko połączył przeszłość i teraźniejszość Ukrainy w filmie Zwenigora (scenariusz Jurij Tiutiunnyk, Mike Johansen, reżyseria Ołeksandr Dowżenko, zdjęcia Borys Zaweliew, scenografia Wasyl Kryczewski. Obsada: Mykoła Nademski, Semen Swaszenko, Łeś Podorożny, Georgij Astafjew, Iwan Seliuk, Leonid Barbe, M. Parszyna, Polina Skliar-Otawa. Wytwórnia Filmowa VUFKU w Odessie, 1928).

Dowżenko dystansował się od filmów komercyjnych i traktował film jako sztukę wysoką, długowieczną.

Nakręcić film, który zmusi widza do obejrzenia go nie jeden raz, lecz wielokrotnie. Jeśli ciągle możemy zachwycać się obrazami Rafaela czy Rembrandta; jeśli możemy czytać Byrona czy Goethego lub słuchać muzyki Beethovena czy podążać za myślami Szekspira — to dlaczego nie można również wielokrotnie zachwycać się cennym filmem artystycznym?32

Ołeksandr Dowżenko odważnie wziął się za bardzo trudny, odznaczający się metaforycznością scenariusz autorstwa Jurija Tiutiunnyka i Mike’a Johansena. Me-

30 „Кіно” 1927, nr 19-20, s. 8.

31 А. Бучма, 3 глибин душі, Київ 1959, s. 28.

32 О. Довженко, Моя метода, „Experimental Cinema”, 5, 1934. 
taforą przewodnią jest poszukiwany od wieków skarb ukryty w Zwenigorze ${ }^{33}$. Motyw skarbu w filmie pozostał, jednak najważniejszy jest w nim klasowy rozłam ludu ukraińskiego, co niestety miało miejsce w rzeczywistości. Historyczne wizje i legendy pojawiające się w filmie Zwenigora, zwłaszcza te dotyczące Scytów i Waregów, były piękne, ale dość umowne. Znacznie bardziej konkretnie rysowały się czasy mniej odległe: hajdamaczyzna i I wojna światowa. W kontekście naszych badań zainteresowani jesteśmy pierwszą częścią filmu: ukazano w niej szukających skarbu hajdamaków i polskich panów.

$\mathrm{W}$ Zwenigorze patos łączy się z ironią, szczególnie wyrazista jest ona w scenach starć hajdamaków z Polakami. Polacy, którzy wspięli się na drzewo, by strzelać do hajdamaków, jeden po drugim spadają od hajdamackich kul niczym gruszki. Scenę tę Dowżenko zaczerpnął z poematu Hajdamacy Tarasa Szewczenki.

Wydawałoby się, że twórczość Dowżenki jest na Ukrainie gruntownie zbadana; wykazano związek jego filmów z estetyką ukraińskich dum i baśni. Jednak nikt nie zwrócił uwagi na to, że ta część filmu jest bezpośrednio związana z twórczością Tarasa Szewczenki, że jest ekranizacją rozdziału Hupalowszczyzna z poematu Hajdamacy. W rozdziale tym fabułę (powstanie hajdamaków) Szewczenko łączy z komentarzem autorskim. Pokazując przejawy gniewu przeciwko polskim wyzyskiwaczom, nie zgadza się z tym, że jest to ślepy los: gniew ludzi narastał przez długi czas:

Jednej matki, jedne dzieci, — / Żyć by i nie sarkać. / Nie, nie chcieli, nie umieli, / Trzebaż się potargać! / Trzeba krwi braterskiej... za co? / Za to, że u brata / Jest w komorze i we dworze / I wesoła chata! / „Zduśmy brata! spalmy chatę!” / Rzekli, wykonali ${ }^{34}$.

Ale po bratobójstwie — pisze Szewczenko — zostali sierotami, które wyrosły i „krew więc za krew / I męki za męki. / Serce boli, skoro wspomnisz: / Słowian starych dzieci / Krwią się spili, a kto winien? / Księża, jezuici”. Do ostatniego zdania poeta dodaje uwagę: „Do czasów unii Kozacy żyli z Lachami w pokoju, gdyby nie jezuici, być może nie doszłoby do rzezi; jezuita Posiewin, legat papieski, pierwszy rozpoczął unię na Ukrainie" 35 .

33 Jurij Tiutiunnyk pochodził ze wsi Budyszcze koło Czerkas; niedaleko znajdowała się Kiryłówka, w której urodził się Taras Szewczenko.

34 Hajdamacy Tarasa Szewczenki w thum. Leonarda Sowińskiego — przyp. tłum. P.J.

35 „W sprawie unii, w drodze wyjątku, jeszcze w latach 80. przybył do Polski wysłannik papieski A. Possevino, jedna z głównych postaci zakonu Jezuitów. Przedstawił on szczegółowy plan połączenia kościołów w tej »części Rusi«, która należała do państwa katolickiego. Wyraził on przekonanie, że nawrócona Ruś (czyli Ukraina i Białoruś) »stanie się potężną machiną, dzięki której uda się pokonać schizmę w Moskowii«". Zob. Д.С. Наливайко, Західна рефлексія щуодо участі козаків y боротьбі з католицькою та польсько-шляхетською експансією, [w:] Історія українського козаитва. Нариси у двох томах. Том другий, Київ 2007, s. 238. 
Szewczenko wspomina o skarbie w wąwozie, o lochach i porównuje polskich konfederatów $^{36}$ do zgniłych gruszek. Wątki te wykorzystał Ołeksandr Dowżenko. W tekście libretta Zwenigory, wprawdzie z dodatkowym opisem mnicha, wygląda to następująco:

Ukraińcy walczyli z polskimi panami w czas hajdamaczyzny, koliszczyzny i hupalowszczyzny. Walczyli i zwyciężali, a pokonawszy wroga, chcieli odebrać to, co zabrano im w ciągu długich lat niewoli. Rujnowali kościoły, niszczyli miasta, rabowali panów i szukali zakopanych przez nich skarbów. Ale widmo katolicyzmu, jak ów mnich z lichtarzem w ręku, nawiedzało ich i zmuszało do ucieczki. Stara średniowieczna kultura katolicka przerażała ciemnych buntowników ${ }^{37}$.

Hajdamacy jadą konno - scena w zwolnionym tempie. Spotykają starca (u Szewczenki to chłopiec w sukni), który opowiada im o ukrytym skarbie. Chce ich tam zaprowadzić - rozprzęga swój wóz, wsiada na konia, dobywa szablę i rusza na czele oddziału. Dalej to już strofy Hupalowszczyzny dosłownie przeniesione na ekran:

„A w lesie skarb. Gdy przyjedziem, / Każ, by otoczyli. / Może kogo strzec podziemia / Lachy zostawili.” / Przyjechali, naokoło / U lasu stanęli; / Patrzą się — nikogo nie ma... / „Djabli ich nie wzięli! / Ile gruszek urodziło! / Bijcie do stu katów! / Prędzej! żwawo! dobrze, chłopcy!” / Rój konfederatów / Posypał się z drzew na ziemię, / Jak gruszki lecieli.

W Zwenigorze hajdamacy strzelają do polskich panów, którzy ukryli się w koronie rozłożystego dębu — po każdym strzale ktoś spada. Nowatorstwo reżysera przejawia się w umiejętności łączenia fikcji z rzeczywistością. W scenie tej, a jest to charakterystyczna stylistyka filmu, mamy do czynienia ze złożoną mieszanką gatunków. Ówcześni krytycy doszukiwali się tu różnych interpretacji i były one dość trafne: „Zwenigora nie jest ani feerią w przeciwieństwie do Sindbada, ani operą jak Pierścień Nibelungów". Autor recenzji zauważył, że Dowżenko, łącząc style, kładzie „,kolory z romantycznej palety, co pozwala na wprowadzenie ironii, karykatury, wizji i hiperboli” 38 . „Oczywiste jest, że szlak od Waregów do nowej Ukrainy nie jest szlakiem od feerii czy opery do kroniki, ale drogą rozwoju filozofii narodowej, odkrytą w scenach romantycznych" 39 . W. Łewycki definiuje styl Dowżenki jako swego rodzaju monumentalizm ${ }^{40}$.

We wspomnianej scenie ironia nie jest przypadkowa i ma swe wyjaśnienie. Twórczość jest przecież nierozerwalnie związana z biografią artysty, a życie Dowżenki było stale zagrożone. Reżyser miał podstawy do odczuwania wrogości wobec Polaków i to nie tylko z powodów politycznych, lecz także ze względu na

36 W Polsce XVI-XVIII w. tymczasowe związki szlacheckie o charakterze wojskowo-politycznym, powoływane w celu osiągnięcia pewnych korzyści. Zob. Словник української мови, Київ 1972, s. 273.

37 Libretto filmu Zwenigora. Zob. Звенигора, Київ 1928, s. 7.

38 Мик. У., „Звенигора”, „Літературна газета” 1928, 25 lutego.

39 Ibidem.

40 В. Левицький, Кіно. Фото. Радіо, [w:] Енциклопедія українознавства, t. 1, III, 1949, s. 888. 
wydarzenia z własnego życia. Z autobiografii dowiadujemy się, że w kwietniu 1920 roku wyznaczono go na dyrektora szkoły partyjnej w Żytomierzu, jednak musiał się ukrywać, kiedy połączone wojska polskie i URL nacierały na Kijów.

Nasi wycofali się do Kijowa, a mnie wysłano do partyzantów w rejonie Korowynieckim, gdzie zostałem wzięty do niewoli przez polski patrol konny.

Patrol zachował się względem mnie szczególnie brutalnie. By zmusić mnie do zdradzenia lokalizacji naszych sił, poddano mnie sfingowanej egzekucji. Patrol został zaatakowany przez nasze oddziały, a podczas wymiany ognia, zrobiono ze mnie żywą tarczę. Jednak udało mi się uciec do Armii Czerwonej ${ }^{41}$.

Kolejne niezbyt przyjemne wspomnienie wiąże się z pobytem Dowżenki w Warszawie podczas jego służby dyplomatycznej. Po przyjeździe do Warszawy, „personel przedstawicielstwa dyplomatycznego USRR w Polsce trzy dni mieszkał W wagonie na stacji towarowej"42. W końcu zorganizowano im lokal. Przedstawicielstwo mieściło się na ulicy Jasnej (równoległa do Marszałkowskiej). Co więcej, charakter jego obowiązków w okresie od października 1921 do kwietnia 1922 roku nie odpowiadał jego twórczym aspiracjom: najpierw zajmował się wymianą jeńców wojennych w rosyjsko-ukraińsko-polskiej komisji repatriacyjnej, a następnie został szefem administracji. „Praca biurowa w warunkach roku 1921 była tak nieprzyjemna i nudna, że nie opuszczałem ambasady przez wiele tygodni” — wspominał w swojej autobiografii Dowżenko ${ }^{43}$.

Jednak każdy, kto widział Zwenigorę, wie, że Dowżenko nie tylko Polaków ukazywał w złym świetle. W porównaniu z tym, jak przedstawiono ukraińską emigrację „gruszki padające z dębu” są jedynie niewinnym żartem. Pawła — przeciwieństwo ukraińskiego bolszewika Tymofieja i jego brata - wyśmiano bezlitośnie, była to karykatura polityczna. Choćby za to bolszewicy powinni być wdzięczni Dowżence. Jednak na początku 1930 roku, kiedy władza rękami oficjalnych krytyków zaczęła bezlitośnie prześladować ukraińskich twórców, nie oszczędzono i jego: Zwenigorę krytykowano, doszukując się „wpływów burżuazyjno-nacjonalistycznych”, a znaną w świecie Ziemię pośledni poeta Demian Biednyj skrytykował w gazecie „Izwiestija", nazywając film obrazem kułackim. Dowżence tylko cudem udało się uniknąć represji; twórca opuścił Ukrainę i zaczął pracę w Mosfilmie. Do tematu Polski Dowżenko powróci jeszcze w latach 30.

Słynny rzeźbiarz Iwan Kawaleridze, którego zaproszono do pracy w filmie, za podstawę swojego debiutu reżyserskiego wziął tematykę historyczną. W 1929 roku pojawiły się informacje o premierze filmu Ulewa (Akwaforty o historii hajdamaczyzny, scenariusz, reżyseria i scenografia Iwan Kawaleridze, zdjęcia Oleksij Kalużny, muzyka P. Tołstiakow. Obsada: Iwan Marjanenko, M. Petliszenko, Seweryn

41 О. Довженко, Автобіографія, [w:] idem, Твори в n'яти томах, t. 1, Київ 1966, s. 26.

42 М.В. Куценко, Сторінки життя і творчості О.П. Довженка, Київ 1975, Дніпро, s. 23.

43 О. Довженко, Автобіографія [w:] idem, Зібрання творів у п'яти томах, t. 1, Київ 1964, s. 27. 


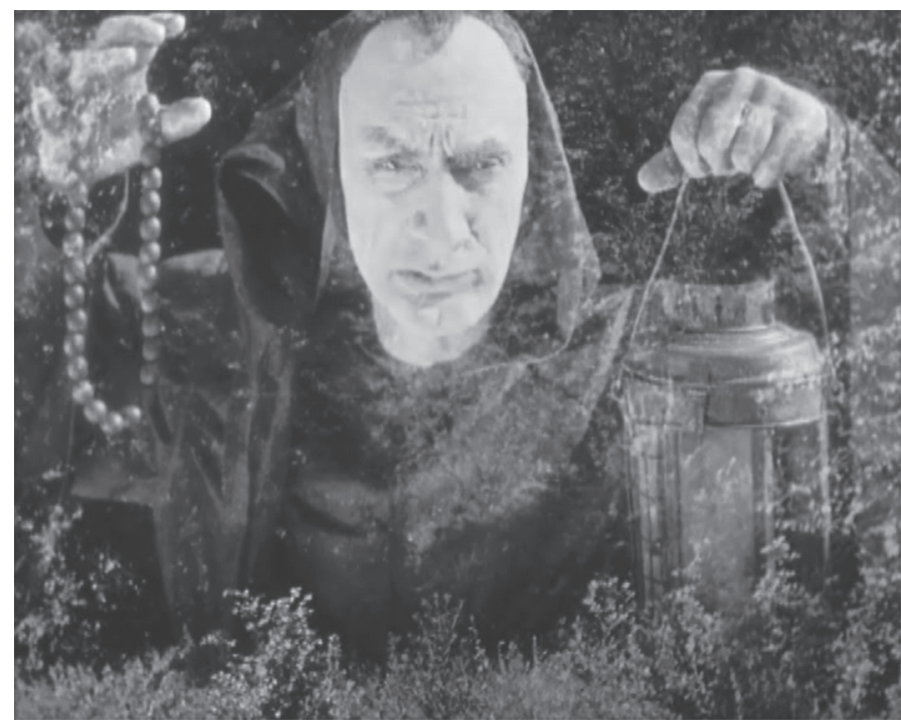

2. Katolicki mnich wychodzący z podziemia i przerażający hajdamaków. Kadr z filmu Zwenigora. Reż. Aleksander Dowżenko, VUFKU, 1928

Pańkiwski (jezuita), H. Biłow. Wytwórnia Filmowa VUFKU w Odessie). Film był nietypowy. Magazyn „Kino” opisał go w następujący sposób:

To film-akwaforta opowiadający historię hajdamaków. Ulewa to nowe wielkie osiągnięcie kina ukraińskiego. Operator O. Kalużny okazał się w tej pracy prawdziwym mistrzem. W rolach głównych wystąpili Marjanenko, Petliszenko, Czarski, Pańkiwski i inni ${ }^{44}$.

Akcja filmu obejmuje 200-letni okres historii narodu ukraińskiego — od powstania hajdamackiego po wydarzenia z lat 1918-1920.

Tematem filmu była hajdamaczyzna (koliszczyzna), czyli niepokoje społeczne na Prawobrzeżnej Ukrainie. Największe rozmiary osiągnęły w 1768 roku, a na ich czele stali Maksym Zalizniak i Iwan Honta. W czasach panowania polskiej magnaterii i szlachty na prawym brzegu Dniepru znalazło się wielu zbiegłych chłopów, drobnych rzemieślników i przesiedleńców nastawionych bardzo negatywnie do panów i duchownych katolickich. Największe powstanie hajdamackie, zwane koliszczyzną (od ukr. кіл, broń, w którą uzbrojeni byli powstańcy) miało miejsce w 1768 roku; hajdamacy i chłopi mieli nadzieję na pomoc wojsk rosyjskich, które gotowały się do walk z polską konfederacją barską. Jednak rząd rosyjski, obawiając się problemów z Turcją, przez której terytorium przeszedł jeden z oddziałów hajdamaków, nakazał generałowi Kreczetnikowi zdusić bunt. Powstanie zostało brutalnie stłumione, a jego uczestnicy ukarani. Tradycja literacka (Taras Szewczenko, ,szkoła ukraińska” w literaturze polskiej) upoetyzowała hajdamaków.

44 Злива, „Кіно” 1929, nr 7, s. 6. 
Film Ulewa składał się z sześciu akwafort. Przedstawiając epopeję hajdamaczyzny, reżyser filmował postaci w pawilonie, oświetlając je na tle czarnego aksamitu i sukna oraz dekoracji o geometrycznych kształtach. Był to eksperyment: Iwan Kawaleridze spróbował połączyć film i rzeźbę, wykorzystując światło jako środek plastycznej charakterystyki bohaterów. „Próba zbliżenia filmu z rzeźbą była dość naturalna - artysta starał się nadać heroicznym obrazom rozmiar monumentalnej rzeźby" ${ }^{\prime 4}$. Do epoki stylizowano kostiumy i dekoracje.

W niezwykły sposób rozwiązano scenę powstania chłopskiego. Powstańcy byli filmowani podwójnie i potrójnie; poruszali się wówczas rytmicznie na małej przestrzeni w różnych kierunkach. Ich sylwetki oświetlane były promieniami reflektorów; w zasadzie wyłaniały się z mroku i w podobny sposób znikały, sprawiając wrażenie potężnej „ulewy” ludzkiego gniewu. Operator O. Kalużny był prawdziwym partnerem twórcy zarówno poprzez przekazywanie rytmu wydarzeń, jak i tworzenie na ekranie autorskiej plastyki. (...) Operator wykorzystał światło jako czynnik konstruktywny ${ }^{46}$.

Kawaleridze napisał, że był pod dużym wpływem słynnej sztuki Hajdamacy Łesia Kurbasa (według poematu Tarasa Szewczenki). Wydarzenia historyczne potraktowano umownie, dlatego film nie został przez wszystkich zrozumiany. Jak pisała ówczesna prasa, Ulewy i Arsenału Dowżenki nie zrozumiała robotnicza widownia Kijowa. Zaistniała sytuacja zmusiła kierownictwo partii do zastanowienia się nad tym, dlaczego publiczność woli efektowne filmy amerykańskie i czy nie wciąga jej „obywatelskie bagno”, wszakże „drobnomieszczańskie ugrupowania, walcząc na froncie kultury, próbują utrzymać stare pozycje, stawiając przeszkody na drodze rozwoju socjalistycznej kultury"47. Autor recenzji F. Luczanski broniąc Ulewy, uważał za niefortunny dobór tematu. Jego zdaniem nie ma znaczenia, że fabuła nie jest zgodna z prawdą historyczną, najważniejsze, że film ,jest przeniknięty szeregiem tematów społecznych, połączonych pod jednym sztandarem walki z właścicielami ziemskimi”48.

Kino lat 20. charakteryzowało się otwartością na sprawy narodowe: kręcono filmy o życiu Żydów (adaptacje dzieł Szolema Alejchema), Tatarów krymskich, Polaków - czyli tych narodów, które zamieszkiwały terytorium USRR. O ile jednak podczas realizacji tematów żydowskich nacisk kładziono na sprawy dnia codziennego, a przedmiotem filmów o Tatarach krymskich były postaci obrońców biednych warstw przed bogaczami, o tyle w kwestii polskiej na pierwszy plan wysuwała się polityka, co było warunkowane złożonymi stosunkami na poziomie międzynarodowym między ZSRR i Polską. Niestety, przeglądu filmów z lat 20. nie można uważać

45 Украинское кино, [w:] История советского кино 1917-1967 в четырех томах, t. 1, Москва 1969, s. 600.

46 Історія украӥнського радянського кіно, t. 1. 1917-1930, Київ 1986, s. 154.

47 Ф. Лучанський, Проти «зливи» відгуків - за «зливу» культурної революиіï, „Кіно” 1929, nr 11, s. 4.

48 Ibidem 
za zakończony: część z nich — Niebieska paczka, Taras Triasyło, Cienie Belwederu i Za ściana — jest niedostępna; z tego względu przedstawiono je jedynie na poziomie informacyjnym. Jednak w filmach, które można obejrzeć (PKP, Zwenigora, Ulewa) wyczuwalne jest, jak bardzo bolesna była tematyka polska w kinie lat 20 . Dziś filmy te są uzupełnieniem wiedzy nie tylko w zakresie poziomu ówczesnego kina, lecz także mechanizmów działania ideologii bolszewickiej.

\section{TEMATYKA POLSKA W FILMACH USRR LAT 30.}

Na początku lat 30. w Kraju Rad ostatecznie formuje się system totalitarny, następuje unifikacja sfery politycznej, gospodarczej i kulturowej życia społecznego. Teoretycznym uzasadnieniem takiej polityki była teza mówiąca o tym, że wraz $\mathrm{z}$ rozwojem socjalizmu walka klasowa zaostrza się. W szeregach partii bolszewickiej i w Armii Czerwonej dochodzi do masowych czystek, w świadomość ludu implementowany jest obraz wroga, narasta histeria podejrzeń, ujawnianie „wrogów ludu”, „szpiegów”, „sabotażystów” itd.

Jeszcze w latach 20., kiedy można było publicznie przedstawiać swoje stanowisko w sprawie perspektyw społecznych i wartości narodowych, lider pisarzy ukraińskich, Mykoła Chwylowy, w serii artykułów polemicznych Myśli pod prąd oświadczył, że Ukraina musi wejść na własną ścieżkę rozwoju: „Naród ukraiński przez kilka wieków szukał wyzwolenia; oceniamy to jako nieodparte pragnienie odkrycia i wydobycia swego narodowego (nie nacjonalistycznego) jestestwa"49. W jego opinii wyzwolić się z prowincjonalizmu i dogonić inne narody Ukraina może, jedynie realizując hasła „Precz od Moskwy!”, „Dajesz Europo!” (hasła aktualne i dzisiaj). Stalin traktował takie poglądy jako niespotykaną arogancję i nakazał zakończyć ukrainizację, rozprawiając się z jej twórcami. Narodowe odrodzenie na Ukrainie, rozwój kulturalny lat 20. w ciągu zaledwie kilku lat zamienił się w Rozstrzelane Odrodzenie - zdecydowana większość artystów i pisarzy dostała kulę w potylicę albo zginęła na katordze w Gułagu ${ }^{50}$. W tym samym czasie „,dobrowolnie” zjednoczone w 1922 roku niepodległe państwa tracą autonomię w dziedzinie ekonomii, polityki i kultury.

Wszystkie te przemiany miały wsparcie propagandowe. Przed rozpoczęciem represji powstał oddział ochotników, którzy szczuli w prasie i na różnych spotkaniach „kontrrewolucjonistów” i „nacjonalistów”. Rola kina jako narzędzia propagandy wzrastała. Nadzorował je sam „wódz” Józef Stalin. Do zadań kina należało: wychwalać partię bolszewicką, przodowników pracy, wykrywać „wrogów”, wtłoczyć do świadomości społecznej ideę nienaruszalności „związku republik radzieckich”

49 М. Хвильовий, Думки проти течї, „Культура і побут” 1925, грудень.

50 GUŁAG — ros. Главное управление лагерей (abrewiatura nie jest thumaczona). 
i wprowadzić ją na karty historii. Argumentom historycznym, które przemawiały za imperium, filmowcy nadawali właściwą formę: już w 1936 roku na ekrany kin w Moskwie wchodzi Piotr I, obraz sławiący cara, który został imperatorem, osiągając znaczne sukcesy w zajmowaniu kolonii. Mit Supermana utwierdził Siergiej Eisenstein w Aleksandrze Newskim. Na Ukrainie charyzmatycznego wodza ukazano w filmie Bohdan Chmielnicki Ihora Sawczenki (o tym filmie poniżej).

Ukraiński przemysł filmowy, który jeszcze w 1926 roku stał na wysokim poziomie, na początku 1930 roku uchwałą rządu w Moskwie został scentralizowany. Wskutek utraty samodzielności ekonomicznej następuje regres, filmy są brutalnie cenzurowane i wycofywane z produkcji przez urzędników moskiewskich. Miejsce represjonowanych filmowców zajmują kadry delegowane z Moskwy, środowisko filmowe ulega rusyfikacji. Podczas gdy miliony ludzi umierały z głodu, życie na ekranie kipiało energią — praca fizyczna, wyścig pracy, sukcesy industrializacji, kolektywizacji, walka nowego ze starym - wszystko to w rytmie takich samych energicznych melodii. Jednostka pojawiająca się na ekranie to sztuczny wytwór ideologów. Filmy powstałe w latach 30., w których gości tematyka polska - Szczors i Wyzwolenie Dowżenki, Wiatr ze Wschodu Abrama Rooma, Bohdan Chmielnicki Ihora Sawczenki i inne omówimy, uwzględniając kontekst historyczny tego czasu.

W warunkach represji pozostało niewielu śmiałków, którzy nie obawialiby się pokazać historii Ukrainy. Nie bał się Iwan Kawaleridze: w 1933 światło dzienne ujrzał jego film Koliszczyzna (Akwaforty o historii Hajdamaczyzny, scenariusz i reżyseria Iwan Kawaleridze, zdjęcia Mykoła Topczij, scenografia Milica Symaszkewycz, muzyka P. Tołstiakow. Ukrainfilm, Wytwórnia Filmowa w Odessie). Śledzimy te same wydarzenia, co w Ulewie, jednak tym razem reżyser nie chciał eksperymentować, styl filmu był bardziej realistyczny. Za podstawę scenariusza Kawaleridze przyjął dokumenty historyczne o wydarzeniach z lat 1767-1768: Księge kodeń$s k a^{51}$ polskiego kolegium wojskowo-sędziowskiego i zapisy dotyczące powstania autorstwa osób wówczas żyjących. Akcja rozgrywała się w różnych miejscach: w ukraińskiej wsi, w pałacu Katarzyny II, na Siczy Zaporoskiej, w stanicy armii rosyjskiej. Film jest sprzeczny w interpretacji wydarzeń — twórcom dało się tu we znaki narzucone z góry wyobrażenie klasowe dotyczące procesu historycznego: nad przeszłością można było się zastanawiać tylko przez pryzmat walki klasowej, a dla takiej postaci historycznej jak Iwan Honta, który był setnikiem nadwornego wojska polskich magnatów Potockich w Humaniu, ówczesna historiografia wyznaczyła rolę wyzyskiwacza ludu.

W filmie Koliszczyzna reżyser chciał psychologicznie usprawiedliwić działania bohaterów. Zatrudnił znanych artystów, sławnych ukraińskich aktorów teatralnych. Niezwykle wiarygodna jest postać głównego bohatera (odtwarzanego przez Ołeksandra Serdiuka) — garncarza Semena Neżywego stojącego na czele oddzia-

51 Nazwa pochodzi od wsi Kodeń, gdzie odbył się sąd nad powstańcami. 


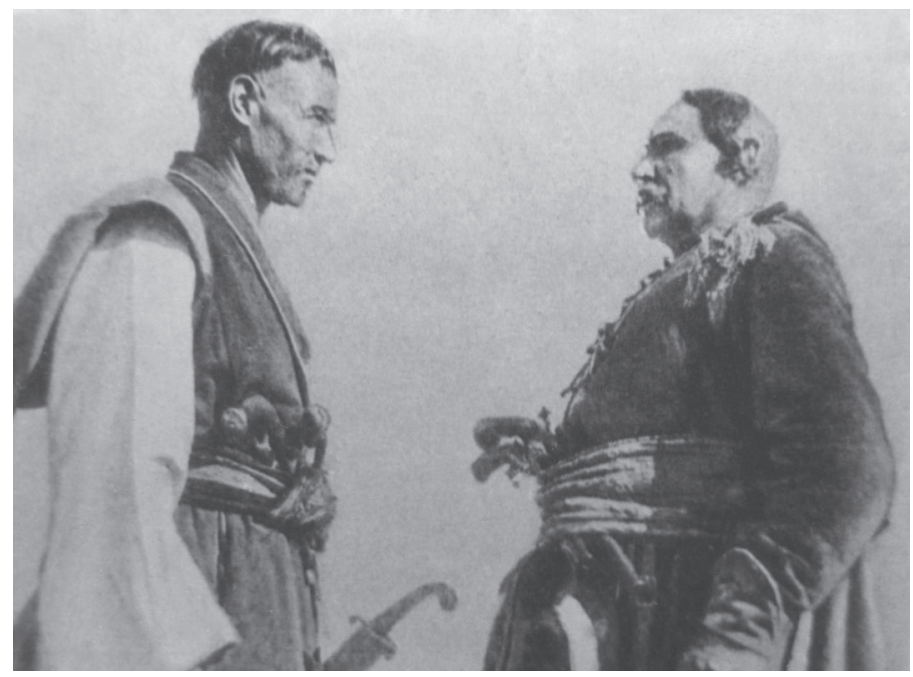

3. Kadr z filmu Koliszczyzna. Reż. Iwan Kawaleridze, Kijowska Wytwórnia Filmów Fabularnych, 1934

łu powstańców. Aktorów wywodzących się z teatru „Berezil”, Iwana Marjanenkę (Honta) i Danyłę Antonowycza (Maksym Zalizniak), widzowie pamiętali jeszcze ze znakomitej sztuki Hajdamacy Łesia Kurbasa. Obydwaj zagrali w tychże rolach, ale ich postaci oceniano negatywnie. Oksanę - narzeczoną Semena - zagrała Polina Niatko, szczerego, skromnego Pawła — Iwan Twerdochlib, wyzyskiwacza Potockiego - D. Szkliarski.

Obok głównego bohatera pojawiają się najmita Pawło z Ukrainy, rosyjski żołnierz Bułatow, żydowski szewc Moszko, polski chłop Staś; wszyscy oni mówią w swych językach ojczystych (pomysł reżysera), co nie przeszkadza im dobrze rozumieć siebie nawzajem ${ }^{52}$.

Badając tematykę Polski w kinie USRR, nie można pominąć filmu Szczors Ołeksandra Dowżenki (1939), w którym obecna jest niewielka, acz pełna ekspresji scena bitwy szczorsowców z Polakami. Dowżenko kręcił film na rozkaz Stalina, mitologizując „bohatera wojny domowej” Mykołę Szczorsa, którego, co dowiedziono już za czasów niepodległej Ukrainy, 30 sierpnia 1919 roku na rozkaz Trockiego zamordował bolszewicki agent ${ }^{53}$. Szczors walczy z ,„petlurowcami”, ugruntowując tezę, że to nie bolszewicy z północy podbili Ukrainę, ale że to swoi walczyli ze swoimi, a z walki tej zwycięsko wyszli bolszewicy ukraińscy. W jednej ze scen Szczors, wówczas już dowódca I Ukraińskiej Dywizji Radzieckiej, został poinformowany, że jego oddział pod dowództwem Czerniaka natknął się na Polaków. Czerniak połączył telefonicznie szefa polskiego sztabu, przebywającego w zam-

52 Історія украӥнського радянського кіно, t. 2. 1931-1945, Київ 1987, s. 88-89.

53 Zob. Е. Марголит, „Кто под красным знаменем?”, „Искусство кино” 1990, nr 9, s. 117 120. A także film dokumentalny След кроваый стелется... Ihora Kobryna, studio „Телекон”. 
ku Wiśniowieckiego, z siedzibą Szczorsa. Ten demonstruje przebłysk talentu dowódczego, grzecznie witając się po polsku, przedstawiając się i rozkazując głośno: „Baczność!”. Widzimy zatem niemłodego polskiego szefa sztabu, który posłusznie wykonuje rozkaz wydany przez telefon i staje na baczność. Podczas rozmowy ironiczny Szczors ujawnia swą wiedzę z zakresu malarstwa: „Mówią, że w waszym zamku jest obraz Jarema Wiśniowiecki bije się z ukraińskim pułkownikiem Bohu$n \mathrm{~m}^{54}$, tak, jesteście otoczeni i rozbici!”. W scenie walki wręcz z polskim wojskiem przebiegającej w pomieszczeniach zamkowych Szczorsa dwukrotnie pokazano na tle wspomnianego obrazu. Nie dzieje się tak przez przypadek: Dowżenko świadomie dąży do analogii między Szczorsem i Bohunem, wywyższając sowieckiego dowódcę. W filmie jest wiele scen batalistycznych — najpierw z Niemcami, później z armią URL. Pokazując bitwy toczące się na Ukrainie w latach 1918-1919, Dowżenko, dla nadania większego znaczenia Szczorsowi, postanowił umożliwić mu również powojowanie z Polakami. Jak trafnie zauważył Jewhen Marholit, „,zamiast ścisłych schematów planów wojskowych — krwawy zamęt, chaotyczne pulsowanie masy (...). A potem zderzenie woli, zderzenie idei, a wszystko z całkowitą obojętnością dla życia i śmierci, nieważne czy swojej, czy obcej" ${ }^{55}$.

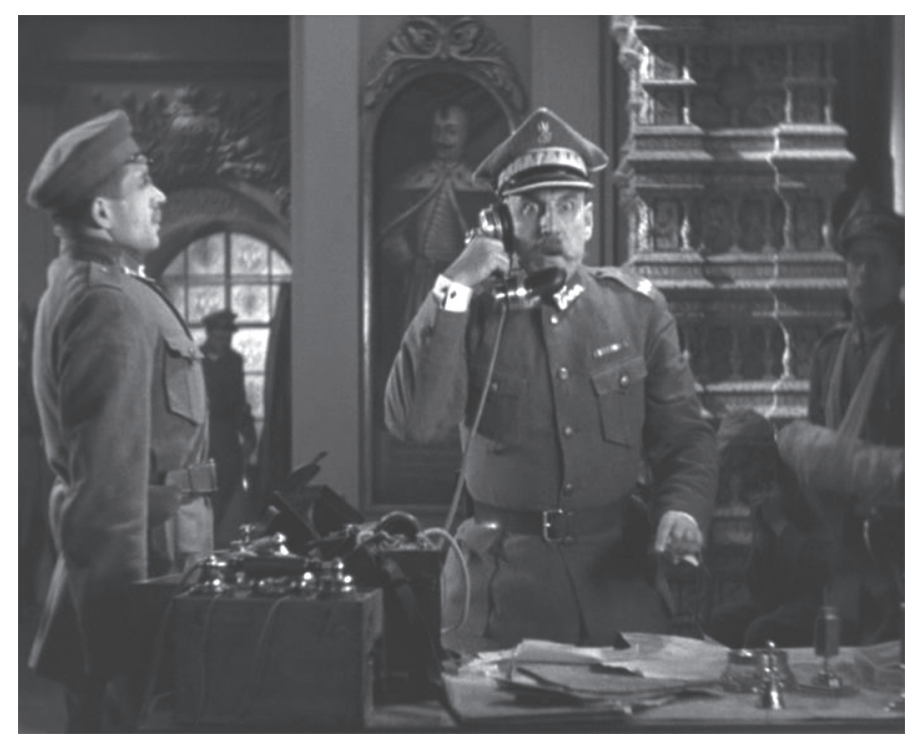

4. Naczelnik sztabu wojska polskiego rozmawia telefonicznie z Mikołajem Szczorsem. Kadr z filmu Szczors. Reż. Aleksander Dowżenko, Kijowska Wytwórnia Filmów Fabularnych, 1939

54 Chodzi oczywiście o obraz ukraińskiego batalisty Mykoły Samokysza Bitwa Maksyma Krywonosa z Jeremim Wiśniowieckim (1934).

55 Е. Марголит, Кто под красным знаменем?..., s. 119. 


\section{OŁEKSANDR DOWŻENKO I JEGO FILMY DOKUMENTALNE}

Po ukończeniu trzyletniej wyczerpującej pracy nad eposem Szczors Dowżenko miał przystąpić do kręcenia Tarasa Bulby, jednak we wrześniu musiał pilnie wyjechać na Zachodnią Ukrainę. Nakręcił tam stylizowany na reportaż film dokumentalny Wyzwolenie (scenariusz Ołeksandr Dowżenko, reżyseria Ołeksandr Dowżenko, Julia Sołncewa, zdjęcia Jurij Jekelczyk, Hryhorij Aleksandrow, Mykoła Bykow, Jurij Tamarski, scenografia Moritz Umanski, muzyka Borys Liatoszynski, Wytwórnia Filmowa w Kijowie, 1940). Było to pierwsze zetknięcie Dowżenki z kinem dokumentalnym. Chodziło o filmowanie wydarzeń, które rozpoczęły się w dniu 17 września, kiedy na rozkaz Stalina Armia Czerwona przekroczyła granicę polsko-radziecką i ruszyła na zachód. Pierwszego dnia operacji wojska radzieckie weszły na $70-100 \mathrm{~km}$ w głąb terytorium Polski, a 19 września były już pod Lwowem.

Ukraińcy nie wiedząc, i nie mogąc wiedzieć, co ich czeka i w co zmieni się to „wyzwolenie”, wychodzili tłumnie na ulice, by powitać wyzwolicieli - ich radość pokazano na ekranie w dużym wymiarze czasowym. Film nazwano „kroniką historyczną". Nie ograniczono się jedynie do Lwowa: o podróży ekipy filmowej po Galicji wspominał J. Dorosz. Jako ukraiński filmowiec, który mieszkał i pracował we Lwowie, poznał Dowżenkę, a ten zaprosił go do udziału w ekspedycji. Zakupiono dwa samochody osobowe i ekipa ruszyła do Przemyśla. Dalej był Stanisławów, Kołomyja, Kosów, Kuty, Krzyworównia, Werchowyna, Jaremcze, ponownie Stanisławów ${ }^{56}$. Film składa się $\mathrm{z}$ dwóch epizodów: zgromadzenia ludowego w huculskiej wsi z wystąpieniem Dowżenki oraz otwarcia 26 października 1939 roku we Lwowie Zgromadzenia Ludowego Zachodniej Ukrainy, Zgromadzenia Ludowego Zachodniej Ukrainy w Białymstoku, uchwalenia Aktu zjednoczeniowego Ukrainy Zachodniej z USRR i V sesji Rady Najwyższej ZSRR.

Film nie należał do priorytetowych, badacze nie zachwycali się talentem Dowżenki-publicysty, patosem heroiczno-romantycznym, stylem narracji. Radzieccy historycy kina również przeszli nad nim do porządku dziennego.

Zestawiając utrwalone obrazy, uzupełniając je objaśnieniami autorskimi, podkreślając ich dramatyzm odpowiednim montażem, zmianą rytmu i muzyką, Dowżenko tworzy poetyckie malownicze wersy o wielkim oddziaływaniu emocjonalnym. Tekst autorski został napisany przez Dowżenkę w dźwięcznym języku ludowym, wabiącym politycznie, zespolonym z obrazem. W filmie Wyzwolenie uderzające są obrazy życia zniewolonych Ukraińców zamieszkujących zachodnie ziemie ukraińskie. Pola rozciągają się aż po horyzont. Przy drodze stoi wysoki krzyż. Chłop orze czarną ziemię. Symbolem ucisku ludu jest kamienny, masywny budynek więzienia ${ }^{57}$.

56 А. Дорош, Довженко в Галичині (зі спогадів Ю. Дорома), „Кіно-Театр” 2004, nr 5, s. 9. Stanisławów — tak wówczas nazywało się miasto Iwano-Frankowsk.

57 W Związku Radzieckim więzień było nieporównywalnie więcej a ludność, zwłaszcza chłopi, cierpieli biedę, jednak nie było to pokazywane ani w filmach dokumentalnych, ani fabularnych. 
Baza dokumentalna (...) nie krępuje fantazji artysty, jego głosu, przesyconego heroiczno-romantycznym patosem ${ }^{58}$.

Mykoła Szudria, scenarzysta i badacz twórczości Dowżenki, podkreśla wagę przedstawionego materiału:

Kampania wyzwoleńcza i spotkanie uzbrojonych żołnierzy z braćmi krwi zaowocowała wieloma wspaniałymi, symbolicznymi scenami; jednego ujęcia kamery filmowej nie można porównać z najbardziej udaną reżyserią. (...) Dowżenko (...) wyznaczył sobie cel: chciał stworzyć nie jakiś specjalny wzorzec sztuki, a jedynie z polityczną namiętnością wynikającą z powodu narodowego święta wyrazić swoje poglądy. Oczywiście pieczęć genialnego mistrza odcisnęła się na całej strukturze i duchu obrazu, a ponadto na montażu i publicystycznej manierze narracji ${ }^{59}$.

Polska badaczka Dobrochna Dabert, w artykule na temat Dowżenki, wspominając o Wyzwoleniu i powołując się na słowa Jerzego Płażewskiego, zaznaczyła:

Ten jawnie antypolski dokument, uzasadniający napad Związku Radzieckiego na Polskę 18 września 1939 roku, został wyemitowany przez polską telewizję publiczną w połowie lat dziewięćdziesiątych w ramach cyklu Kino totalitarne. (...) Możemy się tylko domyślać, iż przed 1989 rokiem, z powodów ideologicznych, nie zezwalano na jakąkolwiek krytykę polityczną czy komentarz filmu przedstawiającego newralgiczny moment relacji polsko-radzieckich. Problem polega na tym, iż również po upadku komunizmu film ten pozostaje nieskomentowany ${ }^{60}$.

Film Wyzwolenie jest pomijany również przez współczesnych ukraińskich krytyków filmowych. Serhij Trymbacz w obszernej książce o O. Dowżence napisał krótko: „(...) dużo politycznego hałasu i deklaracji”61. Słuszną uwagę Lubomyra Hosejki zawarto w Historii ukraińskiego kina:

W kronice filmowej pokazuje on naród dopiero uwolniony spod polskiego jarzma, ale także naród bogaty i cywilizowany. Ludzi wiedzących, czym jest duch wolności, który trudno ukryć przed kamerą. Jest rzeczą oczywistą, że film nie pokazuje fali represji, które przyjdą w ślad za wojskami radzieckimi ${ }^{62}$.

Na tym kończy się analiza filmu.

Rzecz w tym, że komentarz do filmu nie może być oderwany od interpretacji samych wydarzeń, które z punktu widzenia pozycji Ukrainy i Polski nie są oceniane jednakowo. Aktualny stan wiedzy na temat tego, co stało się w Europie Środkowej

58 Украинское кино, [w:] История советского кино в четырех томах, t. 2. 1931-1941, s. 378.

59 М. Шудря, Кінотрилогія: найтрагічніші дні перемоги. Український народ у документальних фільмах Олександра Довженка, [w:] Микола Шудря. Геній найщирішої проби, Київ 2005, s. 103 .

60 Artykuł przetłumaczono na język ukraiński: Д. Даберт, Сприйняття кінотворчості Олександра Довженка в Польщі, przeł. z j. pol., [w:] Кінорежисер світової слави, упор. і редактор Л. Брюховецька, Київ 2013, s. 151-152.

61 С. Тримбач, Олександр Довженко. Загибель богів. Ідентифікація автора в національному часо-просторі, Вінниця 2007, s. 345.

62 Л. Госейко, Історія украӥнського кінематографа, przeł. z fr. Київ 2005, s. 105. 
i Wschodniej we wrześniu 1939 roku (chodzi tu przede wszystkim o pakt Ribbentrop-Mołotow, którego zawarcie było po wojnie starannie ukrywane przez Związek Radziecki), pozwala rozpatrywać wtargnięcie Armii Czerwonej na terytorium sąsiedniego państwa jako akt agresji. Z drugiej strony, po raz pierwszy od stuleci naród ukraiński został zjednoczony w granicach jednej republiki.

Oglądając uważniej Wyzwolenie, można wyciągnąć kilka wniosków: po pierwsze, ten godzinny film jest cennym dokumentem swego czasu - czasu, kiedy masowa psychoza kultu jednostki sięgnęła apogeum. Rytuał zebrań, gdzie by się one nie odbywały, z wyraźnym kanonem przemówień przerywanych długotrwałymi owacjami, wstawaniem z miejsc i okrzykami: „Hura!”, przypomina spotkania nawróconych fanatyków religijnych zjednoczonych w zbiorowej ekstazie, którzy tryskają pragnieniem zamanifestowania swej wiary. Niestety, konsekwencją takiego niesamowitego podniecenia społecznego często są wojny - energia mas, jak powódź, występuje z brzegów. Nasycenie takiego poziomu zbiorowych emocji nie przechodzi bez echa. Jednakże, by być konsekwentnym, należy stwierdzić, że emocje ukazane w Wyzwoleniu miały swoje uzasadnienie. Po drugie, Dowżenko myślał w kategoriach światowych, geopolitycznych i dobrze rozumiał, jak ważne było zjednoczenie ziem ukraińskich. Po trzecie, w filmie dokumentalnym wyczuwalny jest subiektywny wstęp autorski, który bodaj czy nie najwyraźniej widoczny jest w pierwszej części filmu, gdzie Dowżenko ujawnia swoje negatywne nastawienie do „starej Polski”: dawne urazy nie ulegają zapomnieniu. Film ujawnia jednak dylemat Dowżenki jako obywatela. Dopiero obsypany zaszczytami przez „przywódcę wszystkich narodów” za film Szczors, chce podkreślić potęgę Związku Radzieckiego, uszczęśliwiającego Ukraińców swym przybyciem, przedstawić jego siłę ofensywną. Wie jednak, co naprawdę oznacza to radzieckie „szczęście”, przecież jego koledzy zostali rozstrzelani lub wywiezieni do radzieckich obozów pracy. Póki co, myśli te formułują za niego „kapusie” i donoszą tajnym służbom; Dowżenko wyrazi je w Dzienniku pisanym podczas wojny, na froncie.

„Moskwa to dom naszego wielkiego ojca" — słowa te, będące wzorem retoryki tych czasów, wypowiada jedna z wielu mówczyń, dziękując wodzowi za wyzwolenie. Pretensjonalne epitety, którymi mówcy określają obecnych na tym wydarzeniu przywódców: Stalina, Nikitę Chruszczowa, marszałka Siemiona Tymoszenkę, można wyliczać bardzo długo. Kronika wydarzeń na Zachodniej Ukrainie to reportaż filmowy. Mieszkańcy Lwowa witają na ulicach żołnierzy radzieckich okrzykami „Hura!”. Wiece ukazywały „wolę ludu”, ziemie pierwotnie miały status zdobytych, ale już formalizowano ich prawne przyłączenie do ZSRR.

Film można podzielić na pięć części (nie są one wyraźnie zarysowane, a w trzech ostatnich akcja przenosi się z jednego miejsca do drugiego). Pierwsza, to niewolnicze funkcjonowanie Ukraińców w państwie polskim: widzimy chłopów i robotników zakładów naftowych w Borysławiu, choć szczególnie szokujących przykładów nie przedstawiono. Kronika jest neutralna i w innym kontekście mogłaby mieć zupełnie 
odmienny wydźwięk. Film zaczyna się widokiem rzeki Zbrucz, stanowiącej granicę między Polską a USRR: autor ironicznie porównuje ją do Linii Maginota, informuje o fakcie niewolniczego życia Ukraińców w Polsce, szczególny nacisk kładzie na wyliczenie liczby więzień na terenie Ukrainy Zachodniej (187). Pokazano dzieci we wsi Nahujowice, rodzinnej wsi Iwana Franki — zamknięto tam ukraińską szkołę, używanie języka ukraińskiego w Polsce zostało zakazane ${ }^{63}$. Część druga: kolumny czołgów Armii Czerwonej mkną ulicami wsi, podnosząc tumany kurzu, widać samoloty na niebie - ten gwałtowny ruch, któremu towarzyszy brawurowa muzyka, przypomina pokaz siły militarnej z filmów Iwan i Aerograd. Przejazdowi konnicy towarzyszy ukraińska pieśń 3 а світ встали козаченьки. Podkreślono nie tylko potęgę kraju, ale też świadomość nieuchronności wojny, która rozpoczęła się w Europie podczas kręcenia Wyzwolenia. Część trzecia, czwarta i piąta to przejaw narodowego triumfu i prawny aspekt przyłączenia decyzją władz. Ukraińskie Zgromadzenie Narodowe we Lwowie i jego odpowiednik w Białymstoku (zachodnia Białoruś), Rada Najwyższa i Rada Najwyższa USRR w Kijowie. Na posiedzeniu występują kolejni płomienni mówcy, oklaski i okrzyki: „Hura!”. Film opatrzony jest komentarzem (więcej jest go na początku). Dziś ważne jest nie to, o czym mówią oratorzy (choć dla historyków przemówienia są materiałem źródłowym) — retoryka i treść jest identyczna - ale moc ludzkiego temperamentu i demagogii, które są wyczuwalne w poszczególnych wystąpieniach. Co ciekawe, inteligencja odczytuje swoje wystąpienia, natomiast „przedstawiciele mas” wygłaszają je na tyle dobrze zestawionymi głosami, że zakrada się podejrzenie, czy nie są to aby aktorzy?

Wspaniałe symbole Dowżenki z perspektywy czasu nie są tak jednoznaczne, jak w chwili ich powstawania. Postacie negatywne - nacjonalista-emigrant Pawło ze Zwenigory, kułak Tomasz z Ziemi, hulaka z Iwana nie są uosobieniem zła, wręcz przeciwnie, bohaterowie ci wywołują współczucie. Analogicznie postrzegane są „postacie negatywne” w Wyzwoleniu. Życie miejskie Polski Dowżenko ilustruje wesołą melodią Krakowiaka i występem ulicznego akrobaty, wkładając w to oczywiście treści metaforyczne. Szybką klęskę Polski okupowanej przez Niemcy ocenia jako skutek jej dyskryminacyjnej polityki wobec Ukraińców. Zamiast współczucia wobec podbitego przez nazistów kraju brzmią brutalne słowa: „Dziesięć dni wystarczyło, żeby sztuczne polskie państwo upadło." Film nie wspomina o pakcie Ribbentrop-Mołotow, który podnosił Niemcy do rangi sojuszników ZSRR, a z Polaków czynił wrogów.

Przykładem umiejętnej propagandy sowieckiej może być scena, gdzie obraz kilku spalonych domów, z których pozostały jedynie kominy i piece, uzupełniają słowa o polskich panach, którzy uciekając, niszczą wszystko na swojej drodze. Atak czołgów i lotnictwa przeplata się z kilkoma krótkimi scenami (zapadającymi

63 Oczywiście O. Dowżenko ani słowem nie wspomniał o ukraińskim ruchu narodowowyzwoleńczym w Polsce, o OUN, które powstało pod koniec lat 20. Niewykluczone, że żyjąc za żelazną kurtyną, nic o tym nie wiedział i nie mógł wiedzieć. 
w pamięć) ilustrującymi „oczyszczanie majątków z wyzyskiwaczy”: starsza sparaliżowana kobieta na wózku inwalidzkim jest wynoszona z domu. Dla Dowżenki to wizualny znak upadku Polski, dziś postrzegany jako okrutne obchodzenie się z chorymi. Rząd radziecki pomaga chłopom ułożyć sobie życie - tezę tę ilustruje grupa ludzi z wielkimi księgami, którzy podzielą pańską ziemię. Ale z dzisiejszej perspektywy rodzi się pytanie, komu będzie przydzielana ta ziemia? Przecież wkrótce uruchomione zostaną kołchozy, do których ściągani będą wszyscy chłopi.

Autorzy dzielą się swoimi wrażeniami ze spotkania z europejskim miastem, jakim był Lwów. Kamera przypatruje się monumentalnym budowlom soboru św. Jerzego, uniwersytetu, opery. Pokazując pomnik jeźdźca w bogatym stroju, lektor szydzi: „Pomnik króla Jana Sobieskiego. Nie mylić z Bohdanem Chmielnickim!” Obraz ten pozwolił na krótką wycieczkę do XVII wieku. A obok innego pomnika Adama Mickiewicza - zebrali się ukraińscy pisarze, kamera rejestruje wystąpienie Ołeksandra Kornijczuka, można zobaczyć również Dowżenkę.

Następnie uwaga skupia się na przeżywaniu wydarzeń przez „wyzwolonych”. „Runęła żelazna ściana dzieląca nasz naród”, a powaliły tę ścianę „stalowe dywizje dowódcy Siemiona Tymoszenki". W kadrze wielokrotnie pojawia się Nikita Chruszczow, którego mówczyni nazwała „naszym komendantem”, bo z jego inicjatywy odbudowywane są zakłady naftowe w Borysławiu.

W filmie pojawia się wyjątkowa scena nakręcona w Krzyworówni. Hucułowie, ubrani w stroje narodowe, spieszą na wiec poświęcony nastaniu nowej władzy. Tutaj Dowżenko odstępuje od ogólnej linii „niewolniczego życia pod polskimi panami" i robi wyjątek, by pokazać talenty, z których słynną Hucułowie — dzielnych i wprawnych w swym fachu flisaków, którzy spławiają drzewo górskimi rzekami, sztukę, rzemiosło, tańce, muzykę ludową, grę na trombitach. Scenom towarzyszą słowa lektora: „Hucułowie to urodzeni artyści”.

Ale co tam Hucułowie! Nawet mnisi z Ławry Poczajowskiej cieszyli się z wyzwolenia (autor jednak nie udźwiękowił ich wypowiedzi). Wybory do władz lokalnych ukazano jako święto $\mathrm{z}$ orkiestrą dętą i dobrze ubranymi mieszkańcami Lwowa. Udokumentowano ówczesną modę mieszczanek i ich efektowne kapelusze. W starym Przemyślu pokazano Nikitę Chruszczowa z wojskami. I wiece, wiece... Wyzwolenie dokumentuje „entuzjazm”, daje pojęcie o jego skali i poziomie emocji.

Masowe wiece w Operze Lwowskiej, gdzie mówcy na tle profilu Lenina i Stalina twierdząc, że nie chcą już dłużej żyć „,pod jarzmem polskich panów”, głoszą postulaty sprawiedliwości społecznej: „ziemia ma być właścicielom ziemskim skonfiskowana, banki i wielki przemysł trzeba znacjonalizować”, „,przyszłych sabotażystów prosi się o opuszczenie naszej ziemi." Na wiecu, w szeregu, ze sztandarem wchodzą na salę bojownicy i stają w przejściach (obecnie postrzegane jest to jak swego rodzaju symbol - jesteście otoczeni), sala ich wita. W Białymstoku Białorusinka woła: „Wystarczająco długo panowaliście nad nami. Basta!”. We Lwowie miejscowa nauczycielka, w przeciwieństwie do profesora Uniwersytetu 
Lwowskiego K. Studzińskiego i doktora medycyny Panczyszyna, przemawia bez notatek, porywając i tak naelektryzowaną salę. „Kapitalizm więcej nie wróci, nie wróci żandarm, bo na straży naszych granic stoi Armia Czerwona" - po polsku zapewnia jeden z uczestników ukraińskiego Zgromadzenia Ludowego. Tak więc pośród mówców byli i Polacy, którzy witali Armię Czerwoną.

Ale dość szybko „Złoty wrzesien”” (tak wydarzenia te nazwali radzieccy ideolodzy) doznał przeszacowania. W 1940 roku, kiedy ekipa kręci film o wyzwoleniu Bukowiny, organy ścigania otrzymują od „czujnych” obywateli donosy na Dowżenkę. Z raportów śledczego 5. posterunku 2. oddziału bezpieki ${ }^{64}$ Czekaldykina dowiadujemy się o nastrojach Dowżenki:

Czerniowce - powiedział (Dowżenko) - to wspaniałe miasto, pełne kultury, gościnne. Życie tam to bajka. Dom, w którym mieszkał metropolita, jest tak piękny, że podobnego nie ma nawet w Moskwie. Ludziom na Bukowinie żyło się o wiele lepiej niż u nas. Kiedy u nas jedziesz pociągiem, to nigdzie nie spotkasz radosnych twarzy, porządnych ubrań. Wszędzie bieda i smutek. Uważam, że nasz naród przygniata fakt, że wszyscy ubierają na szaro (w sposób monotonny). A tam wszystko jest kolorowe, wesołe, przyjemne. (...) W ogóle naszym jest tam źle; na Zachodniej Ukrainie w zeszłym roku witali nas wspaniale, a teraz my doprowadziliśmy do sytuacji, że szerzy się tam powstanie. Hucułów wysiedlono z terenów granicznych, popełniono mnóstwo błędów. Teraz to samo dzieje się na Bukowinie. Łapią ludzi bez rozgraniczenia, i prawych, i winnych ${ }^{65}$.

W najkrytyczniejszym roku wojny z Niemcami hitlerowskimi Dowżenko, odmawiając ewakuacji, przybył na front. W tych ekstremalnych warunkach, od czasu do czasu wracał myślami do wydarzeń z jesieni 1939 roku, których był świadkiem i uczestnikiem. Swe „buntownicze” myśli zapisał w Dzienniku. Zdaje sobie sprawę, że ludzie, „których wyzwoliliśmy”, nie mogli być tacy jak oni, bo nie przeżyli 23 lat pod radzieckimi rządami. 12 kwietnia 1942 pisze: „Napisać nowelę lub opowiadanie o tragedii Zachodniej Ukrainy ostatnich czasów. Nasze wyzwolenie, radość, i patos, i rozczarowanie, i ból, i różne cele..." $" 66$, a po pewnym czasie — stawia te wydarzenia w kontekście sześćsetletniej historii Ukrainy, którą rozerwano, a „obcy wysysali z obu części soki i krew, uczyli różnie modlić się, myśleć”. A rezultat? Obie części Ukrainy na początku bardzo się cieszyły, a potem

rozluźniły się uściski, radość ustąpiła miejsca nienawiści, niepewność — wątpliwościom, wątpliwości przeszły w zdziwienie, zdziwienie w rozczarowanie, a później gniew i oburzenie. Ktoś powiedział — powiedziano, że trzeba więzić, uciskać, strzelać w plecy, zsyłać, znieważać, pluć w duszę, hańbić, nie wybaczać, niczego nie wybaczyć!!! ${ }^{67}$

64 GZBP (ros. ГУГБ — Главное управление государственной безопасности) — Główny Zarząd Bezpieczeństwa Państwowego Ludowego Komisariatu Spraw Wewnętrznych ZSRR.

65 В. Попик, Під софітами секретних служб перебував упродовж всього життя Олександр Довженко. Документи із справи-формуляра на О.П. Довженка, [w:] В. Попик, Під софітами спецслужб, Київ 2000, s. 150.

66 О. Довженко, Зачарована Десна. Украӥна в огні, Щоденник, Київ 1995, s. 284.

67 Ibidem, s. 285. 
Te myśli przyszły naturalnie, bo Dowżenko na każdym kroku widział niekompetentnych dowódców, niepotrzebne ofiary, obawiał się, że Ukraina, która od roku stała w ogniu wojny, może zniknąć z powierzchni ziemi. Otwierały mu się oczy na istotę bolszewizmu i władzę sowiecką. Nie szczędząc krytycznych epitetów w ocenie narodu ukraińskiego, pisał:

Cała nasza nieczułość, nasz strach, zdrada i umywanie rąk, i chamstwo, i głupota, w ciągu całej historii zjednoczenia wschodniej i zachodniej Ukrainy jest, zasadniczo mówiąc, całkowitym aktem oskarżenia, jest czymś, czego historia nie powinna nam wybaczyć, jest czymś, za co ludzkość powinna nas ignorować, jeśliby o nas myślała ${ }^{68}$.

13 lipca tego samego roku, Dowżenko charakteryzuje ludzi, których stworzył ustrój sowiecki, wynaturzenia, których dopuszczał się system sowiecki wobec jednostki, pokazując to oczami mieszkańców Zachodniej Ukrainy, oczami tych, których wyzwolili.

- To, że nas nie lubicie, a odczuwamy to całym sercem, nas nie przeraża. Myślicie, że jesteśmy nacjonalistami, burżujami, szpiclami, że nie wiemy, czym jest marksizm itp. — powiedział mi kiedyś we Lwowie pewien obywatel.

— A dlaczego tak nie lubicie i nie szanujecie się nawzajem? Widzimy to, i to przeraża nas najbardziej. My szanujemy siebie nawzajem, kim byśmy nie byli. A was się boimy. Boimy się waszej buty, pychy, fałszu, boimy się waszego zakłamania, mydlenia oczu, chamstwa. Przeraża nas to, że nie jesteście panami swoich słów, nie macie poczucia godności, i nie wiecie, czym jest szacunek dla samego siebie.

— Boimy się waszej dwulicowości i przyzwyczajenia do kłamstwa. Powiedzcie, dlaczego w socjalistycznym Kraju Rad tak nie szanujecie i nienawidzicie siebie nawzajem? Przecież to widzimy.

Te słowa często wspominam, rozglądając się ostatnimi czasy wokół siebie ${ }^{69}$.

By zakończyć temat „Złotego września”, powołam się na akademika NANU", literaturoznawcę Iwana Dziubę. Spisał on wspomnienia matki swojej żony Marty — Olhy Iwaniwny Leneć z rodu Pelenskich, która w okresie międzywojennym mieszkała w miasteczku Komarno, 36 kilometrów od Lwowa. To osobisty punkt widzenia na wydarzenia tej jesieni, ale z pewnością są one ciekawe.

W pierwszych dniach po ataku Niemiec polskie władze aresztowały w Komarnie całą ukraińską inteligencję. Chcieli ich wysłać do obozu koncentracyjnego. Ale wszystko zaczęło się walić... Tato poszedł do burmistrza: „Dlaczego w ostatniej chwili psuć nasze relacje?” Aresztowanych uwolniono, a ci jeszcze przez kilka dni ukrywali się, gdzie tylko mogli...

Burmistrz dobrze zrobił... Kilka dni później przyszło mu samemu prosić o schronienie przed Niemcami. Tato powiedział: „Ja tu jestem gospodarzem” — i pozwolił mu się ukryć... A kiedy za tydzień lub dwa przyszli czerwoni, i tak go aresztowali... ${ }^{71}$

68 Ibidem, s. 287.

69 Ibidem, s. 299.

70 NANU - ukr. НАНУ, НАН України - Національна академія наук України, Akademia Nauk Ukrainy.

71 I. Дзюба, Не окремо взяте життя, Київ 2013, s. 471. 
Iwan Pelenski „był przykładem kulturalnego chłopa, który już wtedy zajmował się handlem, głównie owocami. Cieszył się szacunkiem u chłopów, zaufaniem u kupców. Był kierownikiem czytelni, spółdzielni, i w gminie"72. Wspomnienia z Komarnego pokazują, jak silna była pozycja Ukraińców w międzywojennej Galicji.

\section{TARAS BULBA — NIEZREALIZOWANY FILM DOWŻENKI}

Myślenie Dowżenki w kategoriach historycznych skłoniło go do „zastanowienia się nad wielką tematyką”. Podkreślał, że „za kilka lat może wybuchnąć wojna”. Tarasa Bulbe traktował jak materiał do filmu o tematyce obronnej. Ponadto, Mikołaj Gogol był jego ulubionym pisarzem. Gogol, pracując nad Tarasem Bulbą, posłużył się ogromnym materiałem historycznym: studiował Historię Rusów, Historię Kozaków Zaporoskich Myteckiego, Opis Ukrainy Beauplana, czytał rękopisy ukraińskich latopisów Samowydca i Hrabianki, wykorzystał almanach Запорожская старина I. Sriezniewskiego, Малороссийские песни, изданные М. Максимовичем, motywy czerpał też z pieśni ludowych i dum. Gogol wysławiał ukraińskich Kozaków, heroizm i chwałę ukraińskich rycerzy. Imperium Rosyjskie dzięki temu utworowi przywłaszczyło sobie bohaterstwo Kozaków. Zwróćmy uwagę, jak Tarasa Bulbę interpretuje współczesny badacz rosyjski:

Otoczenie pieśni, zabawy, które jawiły się w wyobraźni Gogola w tym czasie, nakładały się na wysiłki zdrowego rozsądku, historyczne zasługi Siczy, która, mimo że była wolną republiką, niepodporządkowaną nikomu prócz Boga, to dała ruskiej historii przykład wspólnoty, której na próżno szukał Gogol we współczesnej Rosji ${ }^{73}$.

Dla Rosjan autor Martwych dusz jest pisarzem rosyjskim, a opisane przez Gogola walki Ukrainy o wolność są przez nich postrzegane jako przeszłość rosyjska. Taka interpretacja utworu znalazła potwierdzenie w rosyjskim filmie Taras Bulba Władimira Bortko (studio Lenfilm, 2009), w którym kontrast między ukraińskim ubiorem a językiem rosyjskim, jakim posługują się Kozacy, jest szczególnie rażący.

Dowżence imponował podniosły styl Gogola. Scenariusz reżyserski Tarasa Bulby Dowżenko złożył w Komitecie Kinematografii ZSRR na początku 1941 roku $^{74}$. Dokument został zatwierdzony i skierowany do produkcji w Wytwórni Filmowej w Kijowie. Z datą 1. czerwca ukazał się krótki artykuł Taras Bulba.

72 Ibidem, s. 461.

73 И. Золотусский, Гоголь, Москва 2007, s. 297. Słowa „ruskiej historii” (ros. „русской истории") wprowadzają czytelnika w błąd, ponieważ w XVII w. nie było takiego państwa jak Ruś, a jedynie Księstwo Moskiewskie (później — Rosja), a Kozacy Zaporoscy zamieszkiwali terytorium Rzeczypospolitej.

74 Scenariusz opublikowany. Zob. О. Довженко, Твори в n'яти томах, t. 2, Київ 1964, s. $181-$ 240. 
Postawiłem sobie zadanie — pisał reżyser — by jak najwierniej przenieść na ekran powieść Gogola, przekazać jej romantyczny aromat i jej ducha. Uważam, że historia napisana przez Gogola jest w najwyższym stopniu „filmowa”. (...) W filmie pojawią się wszystkie postacie z powieści, w nienaruszonym stanie pozostanie fabuła i kompozycja utworu ${ }^{75}$.

Twórca nie chce stylizacji, stereotypów w przedstawianiu historii, które pojawiły się dzięki wysiłkom „małorosyjskich” grup teatralnych.

Musimy przywrócić prawdę historyczną. Chcę w taki sposób pokazać początek XVII wieku, by widzowie zobaczyli w Zaporożcach nie stylizowaną bujną masę hołoty i hulaków bez szkół, ale żywych ludzi, prawdziwych rycerzy, silnych swym zorganizowaniem, bezinteresownie odważnych i szczodrych, skromnych ludzi pracy. Pokazać, że Zaporożcy byli nieprzejednani dla wrogów swego narodu. Słowem, chcę tak wybrać aktorów do głównych ról i epizodów, a nawet scen zbiorowych, by widz zobaczył i odczuł jakąś ciągłość, jakieś więzi krwi z nimi ${ }^{76}$.

Sądząc po tym artykule, Dowżenkę interesowali raczej Zaporożcy, a nie ich wrogowie. Tę wysokobudżetową i złożoną produkcję Dowżenko spodziewał się ukończyć już w następnym roku. 22 czerwca ekipa miała wyjechać na plan. Atak hitlerowskich Niemiec przekreślił wszystkie plany.

Przedwojennej Polsce w całości poświęcony jest film Wiatr ze Wschodu (scenariusz Ołeksandr Dubrowski i Wasyl Kuczer ${ }^{77}$ przy udziale Wandy Wasilewskiej ${ }^{78}$, reżyseria Abram Room, zdjęcia Mykoła Topczij. Obsada: Amwrosij Buczma, Walentyna Brzeska, Tetiana Kondrakowa, Olga Żyzniewa, Iwan Stadnyk, Serafyma Stadnykiwna, Rostysław Pliatt, Serhij Martinson, Jewhen Kuryło. Wytwórnia Filmów Fabularnych w Kijowie, 1940).

Była to szybka reakcja na przyłączenie Zachodniej Ukrainy do Ukrainy Radzieckiej, wprawna propaganda misji „pokojowej” ZSRR mającej na celu wyzwolenie ukraińskich chłopów, którzy „doznawali krzywd ze strony polskich wyzyskiwaczy", demonstracja ideologicznego wiernopoddaństwa. W chwili kiedy film się pojawił, ale i później, krytyka w USRR oceniała go pozytywnie.

Opór klasowy w przedwojennej Polsce pokazano w dwóch kolorach: białym - ofiary wyzysku i czarnym - wyzyskiwaczy. Abram Room uważający się za artystę wyrafinowanego, o czym świadczył jego poprzedni film Surowy młodzieniec, nakręcony w Wytwórni Filmowej w Kijowie i zmiażdżony przez oficjalną krytykę za formalizm i pokazanie nie do końca „właściwych” bohaterów, pragnąc się zrehabilitować, nie chciał zniżać się do poziomu prymitywnej agitki. Dowodem na to

75 О. Довженко, Твори в п'яти томах, t. 4. Київ 1965, s. 119.

76 Ibidem, s. 120.

77 Wasyl Kuczer — pisarz ukraiński, jego utwory zaczęto drukować w 1930 r., podczas pracy nad filmem ukazała się jego powieść Ustym Karmaliuk.

78 Wanda Wasilewska - polska i radziecka pisarka, działaczka społeczna, członek KPZR od 1941 r. Od 1939 r. mieszkała w ZSRR, pisała po polsku. W powieściach Ojczyzna (1935), Ziemia w jarzmie (1938) opisała walkę polskich chłopów i robotników przeciw wyzyskiwaczom. Zob. УPE, t. 2, Київ 1978, s. 129. 
jest jedna z głównych bohaterek obrazu Wiatr ze Wschodu — hrabina Janina Przeżyńska. Rzecz w tym, że w filmie daje się zauważyć odejście od jednoznacznego schematu, a także, choć nie do końca jawną, sympatię reżysera i aktorki do hrabiny, pomimo że jej nienawiść do „chłopów” zaakcentowano dość wyraźnie.

Obsada ratuje film od schematyzmu — polskich „wyzyskiwaczy” grają aktorzy rosyjscy, podkreślając pychę swoich bohaterów, zaś mieszkańców Galicji aktorzy ukraińscy (wyjątkiem jest Dubczak, który służy polskim panom i wykorzystuje swoich rodaków). Mieszkańcy Galicji cierpią biedę: ziemia jest im zabierana, są polonizowani, zabierani na front. Walczą jednak, są obdarzeni talentem twórczym, który ujawnia się w pieśniach i tańcach ludowych (podobnie jak w Wyzwoleniu Dowżenki, w filmie Rooma pojawia się scena „Święto w Łętowni”, co stanowi odejście od głównej linii). Muzyka, pieśni i tańce wykonywane są przez zespoły ludowe. Różnica polega na tym, że w Wyzwoleniu sceny te udokumentowano, tu zaś zagrano przed kamerą.

Rok 1938, wieś Łętownia. Piękne krajobrazy, raj na ziemi (sceny kręcono w pobliżu Przemyśla). Ukraińskiemu chłopu Chomie Habrysiowi odebrano ziemię. Postać tę zagrał wybitny aktor ukraiński Amwrosij Buczma, dla którego rola ta była szansą na powrót do lat młodości. Podczas I wojny światowej Buczma, wówczas żołnierz armii austro-węgierskiej, został skazany przez sąd wojskowy za spoliczkowanie oficera. W Przemyślu przyszło mu czekać na wykonanie egzekucji. Uratował go jego talent aktorski - Buczma zaczął symulować szaleństwo i został zwolniony. Istnieją spekulacje, że wspomnienia tych doświadczeń pomogły mu w zbudowaniu swojej postaci. Habryś ma wiele wspólnego z Mykołą Zodorożnym ze Skradzionego szczęścia, słynnego dramatu Iwana Franki. Buczma grał wówczas Zadorożnego na scenie kijowskiego Teatru im. Iwana Franki. Nietrudno domyślić się, dlaczego Abram Room, który do wytwórni w Kijowie przybył z Moskwy i był daleko od ukraińskiej rzeczywistości, powierzył główną rolę Buczmie i zaprosił aktorów ze Lwowa - Josypa Stadnyka, Serafymę Stadnykiwnę, Jewhena Kyryło. Byli to nie tylko wykonawcy, lecz także konsultanci.

W latach 60. film chwalono za grę Buczmy, za pokazanie, że galicyjscy chłopi nie poddają się, walczą o swoją godność. Wspominano również udręczoną (z powodu nieposłuszeństwa wobec Moskwy) Komunistyczną Partię Zachodniej Ukrainy ${ }^{79}$.

Zmienili się panowie, zamiast panów i urzędników z Austro-Węgier pojawili się Polacy, ale chłopom się nie polepszyło. Tak jak poprzednio, Ukrainiec jest u pana dłużnikiem, nie mają go za człowieka, ale chłopa, pańskie bydło.

Wydaje się, że wszystko jest tak, jak było. Jednak nie do końca. Nie te czasy, nie ten chłop. Już wielokrotnie powstawał pod przywództwem Komunistycznej Partii Zachodniej Ukrainy,

79 W działalność KPZU jeszcze w latach 20. ingerowała Moskwa: najpierw usunięto ze stanowisk kierowników partii, a w 1939 r. zlikwidowano ją za kierunek proukraiński. Po śmierci Stalina KPZU zrehabilitowano i uchwalono, że jej likwidacja była bezpodstawna. 
nie raz walczył przeciwko znienawidzonej szlachcie. Naturalnie tej siły KPZU nie można było w owym czasie w filmie pokazać ${ }^{80}$.

Konflikt między hrabiną Janiną Przeżyńską i Chomą rozgrywa się wokół kwestii ziemi. Przeżyńska wybudowała drogę do swego majątku przez chłopską ziemię, a działkę Chomy Habrysia decyzją sądu mu odebrano. Ziemia zaproponowana w zamian jest nieużyteczna. Chłop nie ma gdzie szukać sprawiedliwości. Jednak Choma się nie poddaje: „Ziemia mnie kocha. Chociaż skrawek, ale odbiorę”. Nocą ze swej byłej działki zabiera worek ziemi i przynosi do domu, by choć w taki sposób przywrócić sprawiedliwość i zamanifestować nieposłuszeństwo. Zarządca Mateusz donosi hrabinie o tym absurdalnym czynie, ta jest oburzona „przestępstwem”. Chociaż Mateusz stara się ją przekonać, że przecenia bunt Chomy Habrysia, ta myśli inaczej i wzywa do swojego majątku zbuntowanego chłopa. „Dlaczego ukradłeś moją ziemię?” „Ziemia jest moja — ja na niej pracuję. A ona mnie kocha”. — „Więc jesteś filozofem...” — „Nie wiem. Tak naprawdę...” — „Naprawdę? Wynoś się!”. Po tej rozmowie hrabina pozywa Chomę do sądu za kradzież (widać nie miała innych rzeczy na głowie, tylko walczyć z chłopem). Scena sądu i wyrok: Habryś ma wpłacić do Skarbu Państwa odpowiednią kwotę za spowodowaną szkodę. Zarządca za zgodą hrabiny „szlachetnie” wpłaca za Chomę tę kwotę, a ten musi odpracować dług. Mija rok i na początku wojny Choma otrzymuje powołanie do wojska. W radio, którego słucha hrabina, podano informację, że polski rząd „wciągnął naród w wojnę" i że Mołotow wręczył notę polskiemu ambasadorowi. W majątku hrabiny Przeżyńskiej, po ciężkich walkach, zatrzymali się na popas polscy żołnierze pod dowództwem oficera Stefana. Hrabina karci go za wycofywanie się: „Tacy jak wy zgubili Polskę!”. Oficer nie pozostaje dłużny: „Nie, zgubili ją tacy jak Pani. Wam wszystkiego było mało!”. Przeżyńska rozkazuje sługom spieniężyć jak najwięcej rzeczy. Próba wstrzymania rabowania chłopów, poczyniona przez nauczycielkę Hannę („Ludzi rabują, zabierają wszystko do ostatka”) nie powiodła się. Co więcej, Przeżyńska nakazuje spalić wioskę i na tle pożaru wsiada do samochodu. Atak Armii Czerwonej - samoloty z czerwonymi gwiazdami, czołgi. Habryś usłyszawszy o ucieczce swej oprawczyni, wsiada na wóz i dogania ją.

W rolę hrabiny wcieliła się Olga Żyzniewa, która w latach 20. występowała w wielu teatrach ZSRR, w filmach grała podobne role: pięknych, znudzonych życiem kobiet z burżuazji lub nepu, tak więc jej udział w filmie Wiatr ze Wschodu był uzasadniony. Nie żałowała swej bohaterce ani pychy, ani zwierzchniego stosunku do Habrysia, ani zawziętości. Podczas rozmowy z Habrysiem Przeżyńska ubrana jest w czarną suknię, co podkreśla jej negatywną kondycję. Przedstawiono ją nie tylko w czarnych barwach - wygląda zupełnie inaczej podczas sceny malowania w plenerze: ubrana na jasno, przechadza się wśród drzew rzucających na nią miękkie cienie, widać sztalugi z płótnem. Pokazując młodej nauczycielce Hannie swoją kolek-

80 О. Бабишкін, Амвросій Бучма в кіно, Київ 1966, s. 126-127. 
cję obrazów, z przyczyn zrozumiałych tylko dla siebie wskazuje na płótno Rafaela. Hrabina jest tu nośnikiem kultury wysokiej, co tylko podkreśla jej okrutny charakter.

W filmie pojawiają się rewolucjoniści: partyzant Ukrainiec Andrij oraz polska nauczycielka Hanna. Nie wyglądają jak stereotypowi „stalowi” fanatycy z filmów radzieckich. Oboje są sympatycznymi młodymi ludźmi; ona jest idealistką służącą wybranemu powołaniu - nauczaniu dzieci wiejskich, on jest zmuszony do ciągłego ukrywania się przed policją. Rodzi się między nimi miłość. Impulsem dla Hanny było współczucie dla prześladowanego, którego mimo woli ratuje dwukrotnie. On z kolei, doceniwszy dobre serce dziewczyny, zakochany, szuka powodu, by się z nią zobaczyć: potajemnie przynosi na przechowanie do jej mieszkania zakazaną literaturę. To niespodziewane ciepło ludzkich relacji nie pasuje do tego, co pisali sowieccy krytycy: Hanna pod wpływem młodzieńca „stopniowo uświadamia sobie potrzebę walki klasowej i solidarności ludzi pracy" ${ }^{\text {"1 }}$. Choma Habryś w scenie finałowej, razem z mieszkańcami Łętowni, podziwia sprzęt wojskowy wyzwolicieli i uświadamia sobie, że nie prowadzi to do niczego dobrego. Jak widać, poszczególne sceny i epizody filmu zaprzeczają sprowadzaniu ideologii bolszewickiej wyłącznie do walki klasowej.

Przykładem filmu nakręconego przez profesjonalistę zgodnie z bolszewicką koncepcją ideologiczną jest Bohdan Chmielnicki (scenariusz Ołeksandr Kornijczuk, reżyseria Ihor Sawczenko, zdjęcia Jurij Jekelczyk, scenografia Jakiw Riwosz, muzyka Serhij Potocki. Obsada: Mykoła Mordwynow, Hałyna (Haren) Żukowska, Mykyta Ilczenko, Borys Bezhin, Andrij Iwanczenko, Witalij Policejmako, Mychajło Żarow, Borys Andriejew, Emma Cesarska. Wytwórnia Filmów Fabularnych w Kijowie, 1941. Nagroda Państwowa ZSRR, 1942).

W latach 30. historię Ukrainy napisano na nowo. Bolszewiccy historycy przedstawili Bohdana Chmielnickiego jako feudała, który wykorzystywał naród, a nie wyzwalał go. Wkrótce zwyciężył jednak pogląd, że podczas tej wojny przed Ukrainą stanęła alternatywa - wchłonie ją Polska i Turcja, albo przejdzie ona pod zwierzchnictwo Rosji. Wówczas to Ołeksandr Kornijczuk, za radą Maksyma Gorkiego, rozpoczął pracę nad dramatem historycznym Bohdan Chmielnicki. Ponieważ ideologia względem tej postaci jeszcze się nie wykrystalizowała, dramaturg musiał samodzielnie opanować pewien zakres literatury. Po poradę zwrócił się do największego autorytetu w dziedzinie historii Kozaków zaporoskich — Dmytra Jawornyckiego. Uczony udzielał już wcześniej informacji w tym zakresie malarzom Ilji Riepinowi i Mykole Samokyszowi, kompozytorowi Mykole Łysence, pisarzowi Mychajle Staryckiemu. Kornijczuk pisał scenariusz nie bez wpływu Jawornyckiego i w dramacie Bohdan Chmielnicki (1938), „hetman przeobraził się w narodowego mściciela" 82 .

81 Історія украӥнського радянського кіно, t. 2, s. 60.

82 В. Токарев, Возвращение на пьедестал: исторический комментарий к фильму „Богдан Хмельницкий”, www.history.org.ua/journALL/graf/18/26.pd. 
Nazizm rósł w siłę, a w związku z coraz wyraźniejszymi planami agresji na wschód władze ZSRR zaczęły szykować się do wojny. Rozpoczął się proces reorientacji ideologicznej. Państwo nie szczędziło środków, aby w filmach dowódcy uosabiali silną władzę. W ten sposób utwierdzano nienaruszalność rządzących, którzy przejęli bohaterstwo po swoich przodkach i nie ulega wątpliwości, że zadadzą wrogowi druzgocącą klęskę. Film Ihora Sawczenki Bohdan Chmielnicki, wprowadzony do kin w kwietniu 1941 roku, niemal w przeddzień ataku Hitlera na ZSRR, miał mobilizować do heroizmu. Postać ukraińskiego hetmana wpisała się w ideologię ZSRR.

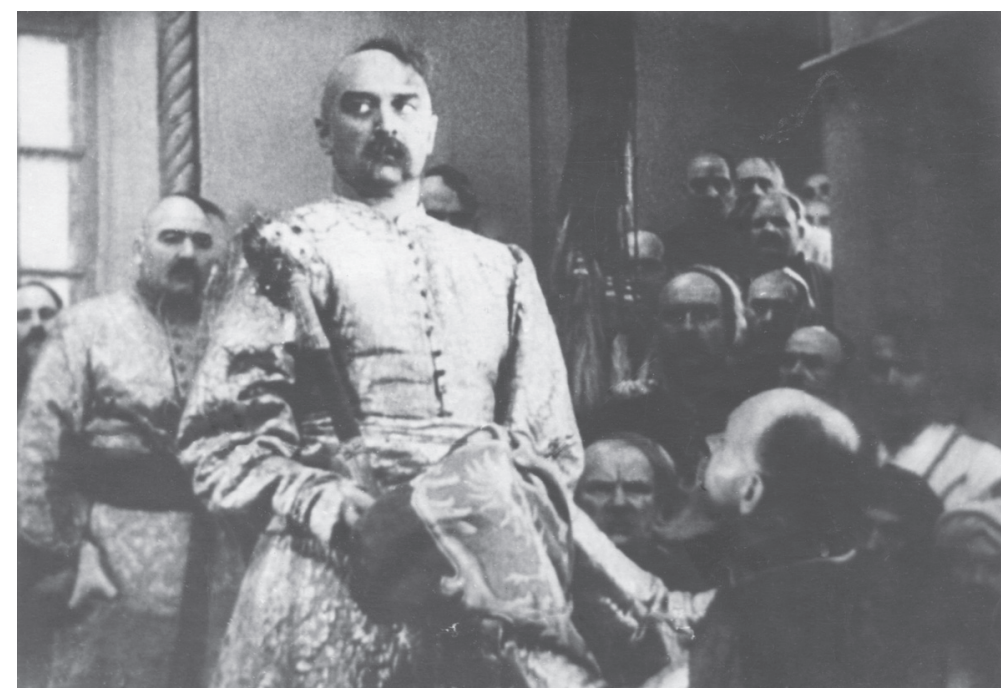

5. Mykoła Mordwinow w filmie Bogdan Chmielnicki. Reż. Igor Sawczenko, Kijowska Wytwórnia Filmów Fabularnych, 1941

Jest to film patriotyczny. Taki punkt widzenia reprezentuje współczesny historyk Serhij Jekelczyk. Jego pojawienie się na ekranach można rozpatrywać w kategoriach postępu, ponieważ wywalczył on prawo Ukrainy do własnej historii.

Na początku wojny radziecko-niemieckiej, w czerwcu 1941 roku, film także „zmobilizowano" jako ważne kino propagandowe. Wyświetlano go bezpośrednio przed wysłaniem wojsk na front. (...) Co ciekawe, w recenzjach na temat filmu nie podkreślano sojuszu z Moskwą, co było przecież rezultatem tamtych wydarzeń. Krytycy i prawdopodobnie publiczność postrzegali Bohdana Chmielnickiego przede wszystkim jako film o „bohaterskiej walce narodu ukraińskiego z polską szlachtą". (...) Miliony Ukraińców po wielokroć obejrzało ten przedwojenny radziecki hit $^{83}$

83 С. Скельчик, Імперія пам'яті. Російсько-украйнські стосунки в радянській історичній уяві, Київ 2008, s. 51-52. 
Niektóre interpretacje filmu wykluczają się nawzajem. Autor artykułu Chmielnicki na dwa sposoby, Janusz Tazbir, przypuszcza, że dramaturg Kornijczuk zapożyczył bohaterów od Henryka Sienkiewicza, bo przed napisaniem dramatu mógł przeczytać rosyjskojęzyczne wydanie powieści Ogniem i mieczem. Argumentuje to tym, że u ukraińskiego dramaturga pojawiają się te same postaci, co u polskiego powieściopisarza - pułkownik Bohun, Mikołaj i Stefan Potoccy, Czapliński, Krzywonos, ukazani jedynie w innym świetle ${ }^{84}$. W rzeczywistości w tamtym czasie historię Chmielnicczyzny badali już tacy ukraińscy historycy, jak Mykoła Kostomarow, Mychajło Hruszewski, Mykoła Arkas, a wspomniane przez Tazbira postacie historyczne były dobrze znane ze źródeł historycznych i twórczości ludowej.

Historię napisania sztuki i scenariusza ironicznie ocenił Wasilij Tokariew, badając krytyczną batalię, która rozegrała się wokół sztuki Kornijczuka Bohdan Chmielnicki. O ile zawodowi historycy potraktowali ją mniej lub bardziej pobłażliwie, zaprzeczając romantycznemu uwiedzeniu osobowością Bohdana Chmielnickiego, o tyle moskiewski krytyk teatralny B. Blum osądził ją ostro: „B. Blum zaprzecza znaczeniu wyzwolenia Ukrainy spod władzy pańskiej Polski i przyłączenia jej do Rosji, widząc w tym fakcie historycznym tylko jedną stronę, a mianowicie, że Ukraina, uwolniwszy się od polskiego ucisku, znalazła się pod butem carskiej Rosji" ${ }^{85}$. Koniunktura polityczna sprzyjała Kornijczukowi — jego sztuka nadawała się do kampanii propagandowej przeciwko Polsce, kiedy ziemie Zachodniej Ukrainy wchodzące w skład Rzeczypospolitej zostały przyłączone do USRR. Według Wasilija Tokariewa, pyrrusowe zwycięstwo nad Polską ze współczuciem przyjęło wielu obywateli Kraju Rad. Kampania w Polsce, a także demontaż propagandy antyfaszystowskiej miały wpływ na aktualizację tematyki polskiej w kinie radzieckim i oczywiście najbardziej wpłynęły na ostateczny kształt i realizację projektu filmowego pt. Bohdan Chmielnicki. Scenariusz oparty na własnej sztuce Kornijczuk przerabiał odpowiednio do sytuacji politycznej, demokratyzacji uległa postać hetmana. W kwestii jednowymiarowego postrzegania postaci Chmielnickiego Sawczenko był tego samego zdania, co Kornijczuk. Chmielnicki był dla reżysera postacią wiarygodną, uosabiającą koniec polskich rządów na Ukrainie - w miarę rozwoju działań zbrojnych Chmielnicki stawał się obrońcą praw nie tylko Kozaków rejestrowych, lecz także biedoty wiejskiej. Gdy trwały jeszcze dyskusje nad scenariuszem, w lutym 1940 roku na naradzie twórczej dotyczącej filmu historycznego Ołeksandr Dowżenko słusznie skrytykował filmową praktykę odwrotu od historii oraz zwyczaj mieszania wypowiedzi bohaterów filmowych z wystąpieniami sowieckich przywódców. Powiedział też, że nie można upraszczać obrazu Bohdan Chmielnicki, którego bohater z przyczyn osobistych rozpoczął walkę z polskimi pa-

84 J. Tazbir, Chmielnicki na dwa sposoby, „Polityka” 1997, nr 40, s. 40.

85 В. Токарев, op. cit., s. 437. 
nami, żył w zgodzie z polskim królem, z którym korespondował aż do jego śmierci, jako jego lojalny sługa ${ }^{86}$.

Wojnę pod przywództwem Bohdana Chmielnickiego historycy ukraińscy określają mianem narodowowyzwoleńczej. Współczesna historyk Natalia Jakowenko kwalifikuje ją jako rewolucję kozacką z lat 1648-1657, podkreślając, że

Nowożytna historia Ukrainy rozpoczęła się od konfliktu, który przepołowił terytorium Ukrainy, a równocześnie, poprzez stworzenie nowego wielkiego imperium — Rosji i zepchnięcie Rzeczypospolitej na krawędź upadku, zmienił istniejący układ sił politycznych w Europie Środkowo-Wschodniej. (...) Wydarzenia Chmielnicczyzny na wiele następnych stuleci, o ile nie do dziś, określiły ideał narodowy, wokół którego w jednym rytmie zaczęła obracać się zarówno kultura elitarna, jak i ludowa: pojawiła się postać bohatera-Kozaka, symbolicznego bojownika „Za wolność Ukrainy”87.

Ze względu na istnienie jeszcze jednego obrazu o Bohdanie Chmielnickim pozwolimy sobie na krótką wycieczkę do historii tych walk w ich ukraińskiej interpretacji, opierając się na Historii Ukrainy-Rusi Mychajły Hruszewskiego oraz książce Historia Ukrainy. Od czasów najdawniejszych do końca XVIII wieku Natalii Jakowenko.

Pułkownik czehryński Bohdan Chmielnicki, doznawszy krzywd od podstarosty czehryńskiego Daniela Czaplińskiego, który najechał jego chutor Subotów, nie znalazłszy sprawiedliwości w polskim sądzie, ucieka na Sicz i na przełomie lat 1647 i 1648 zbiera 8-tysięczne wojsko. Przy wsparciu chana krymskiego przygotowuje kampanię, która ma wyzwolić Ukrainę spod władzy polskich magnatów. Równolegle pisze listy do hetmana koronnego Mikołaja Potockiego, w których, wspominając krzywdy i ucisk Kozaków, prosi o przywrócenie sprawiedliwości — anulowanie ordynacji z 1638 roku, wycofanie z Ukrainy wojsk koronnych i pozwolenie na organizowanie wypraw morskich. Gdy hetman koronny zagroził: „Szybciej doczekacie się pala niż wolności”, Chmielnicki odpowiedział: „Będzie, panie hetmanie, jak Bóg da". Hetman koronny wysyła na Kozaków wojsko pod dowództwem swego syna Stefana. Kozacy rozbili go pod Żółtymi Wodami i szybkim marszem podeszli pod Korsuń, gdzie zadali druzgocącą klęskę głównym siłom wojsk polskich na Ukrainie. Wiadomość o katastrofie wszystkich zszokowała. W tym czasie zmarł król Władysław IV, a do momentu objęcia tronu przez nowego króla władzę sprawował kanclerz Jerzy Ossoliński. W czerwcu rozpoczęły się negocjacje z powstańcami. Chmielnicki przedstawił swoje warunki, a jednocześnie do toczących się rozmów strony konfliktu zbierały siły. Jeremi Wiśniowiecki z 6 tysiącami żołnierzy w akcji odwetowej ruszył z Połtawszczyzny do Czołhańskiego Kamienia, gdzie zbierało się wojsko koronne. Ta krwawa kampania przerwała dalsze negocjacje. Jak pisze

86 А.П. Довженко, Собрание сочинений, t. 4, Москва 1969, s. 125-26.

87 Н. Яковенко, Нарис історії середньовічної та ранньомодерної Украӥни, Київ 2006, thum. na język polski O. Hnatiuk i K. Kotyńska, s. 313; N. Jakowenko, Historia Ukrainy. Od czasów najdawniejszych do końca XVIII wieku, Lublin 2000, s. 215. 
Natalia Jakowenko, ,huragan ślepej nienawiści ciemnego ludu spadł na głowy duchowieństwa katolickiego, szlachty i Żydów, ale wychowany na trzech europejskich uniwersytetach Jarema odpowiedział na to takimi samymi bezsensownymi zabójstwami" ${ }^{88}$. Chmielnicki wkroczył na ziemie polskie 20 września 1648 roku. Przeszkodą była niewielka rzeka Piława. Polacy uciekli przed bitwą. Kozacy poszli dalej, oblegli Lwów, a wziąwszy znaczny okup, ruszyli na Zamość, którego zdobycie otworzyłoby drogę na Warszawę. Chmielnicki celowo opieszale prowadził oblężenie i wreszcie doczekał się wyboru króla.

Nowy król przysłał Chmielnickiemu pismo informujące o wyborze, obiecał Kozakom i wierze prawosławnej pójść na różne ustępstwa, poprosił o wstrzymanie kampanii i oczekiwanie na królewskich komisarzy. Chmielnicki odpowiedział, że wypełni wolę króla — zawraca i rusza $\mathrm{z}$ wojskiem do Kijowa ${ }^{89}$.

Ukraiński dowódca nie zamierzał rujnować Polski, wystarczyło mu rozwiązanie kwestii kozackiej w granicach Rzeczypospolitej. W Perejasławiu do Chmielnickiego przybyli posłowie z sąsiednich krajów, którzy chcieli skorzystać na rosnącej potędze Kozaków. Przybyli również wysłannicy nowego króla Polski, Jana Kazimierza - przywieźli Chmielnickiemu powołanie hetmańskie, buławę i czerwoną chorągiew z białym orłem. Chmielnicki zebrał Radę Kozacką, na której przeważyła opinia, żeby się nie układać i dążyć do decydującego starcia.

Na początku 1649 roku Chmielnicki miał do dyspozycji 80-90 tysięcy żołnierzy. Szlachta polska zebrała armię składającą się z 36 tysięcy ludzi. Wysłannicy króla odmówili podpisania postanowień, gdyż zagrażało to ich majątkom na Ukrainie. Chmielnicki wyruszył z armią z Czehrynia i połączył się z wojskami Islama Gireja. 30 czerwca wojska ukraińskie otoczyły Zbaraż. Po kilku tygodniach w zamku zaczął się głód. Oblężonych wspierał Jeremi Wiśniowiecki. Na pomoc wyruszył król Jan Kazimierz i przybył do położonego nieopodal Zborowa. Chmielnicki pozostawił piechotę pod Zbarażem i ruszył z konnicą na Zborów, atakując niespodziewanie polskie wojska. Kozacy wygrywali, gdy nagle wszystko uległo zmianie i zabrzmiał okrzyk „Zgoda”. Chmielnicki wysłał list do króla, w którym zapewniał, że nie jest buntownikiem. Polacy najpierw zawarli pokój z chanem, a następnie z Kozakami. Ustalono, że na terenie województw kijowskiego, czernihowskiego i bracławskiego ma przebywać wojsko kozackie w sile 40 tysięcy. Nie mogły stacjonować tam polskie wojska, również Żydzi musieli stamtąd wyjechać. Wszystkie stanowiska zajmować mieli tylko prawosławni, jezuici nie mogli mieszkać w Kijowie i innych miejscach, w których będą szkoły ukraińskie, metropolita kijowski miał zasiadać w Senacie. Kwestię anulowania unii, zarówno w Królestwie Polskim, jak i w Wielkim Księstwie Litewskim, miała rozwiązać specjalna uchwała Sejmu. Traktat pokojowy uratował niedobitki polskich żołnierzy, którzy ginęli pod Zbarażem.

88 Н. Яковенко, Нарис..., s. 326. Tłum. Р.J.

89 М. Грушевський, Ілюстрована історія України, Київ-Львів 1913, s. 302. 
Po podpisaniu porozumienia pokojowego wszystkich ogarnęła fala ogólnego szczęścia. Wkrótce okazało się, że warunki ugody zborowskiej nie zostaną spełnione. Duchowieństwo katolickie zagroziło, że opuści Senat, jeśli wraz z nimi w ławach senackich zasiądzie schizmatyk, tak więc metropolita Sylwester Kosiw musiał opuścić Warszawę. Król wydał pozwolenie na odbudowę cerkwi prawosławnych, ale nie miało ono siły sprawczej - dopóki trwała unia, Kościół prawosławny nie mógł być wolny. Zgodnie z ugodą Chmielnicki zaczął formować armię, a szlachcie odbierano ziemię i nadawano ją Kozakom rejestrowym. Na obszarze nowo powstałego Hetmanatu utworzono 16 pułków. W 15 miastach nadal obowiązywało prawo magdeburskie. Reszta ludności miała powrócić pod panowanie szlachty. Lud nie godził się na to, a szlachta powróciwszy do swoich majątków, była zmuszona z nich uciekać. Kozacy rejestrowi także byli niezadowoleni z wyjątkowości swych przywilejów. Gdy na początku 1650 roku Chmielnicki zebrał Radę, by potwierdzić rejestr, spotkały go duże trudności.

Ukraińscy rycerze godnie walczyli z polskim wojskiem, ale stopniowo wszystko zaczęło się zmieniać, kiedy nastał pokój i zawarto sojusz z carem moskiewskim Aleksym w 1654 roku. Kozacy byli uciskani i w XVIII wieku zeszli z areny historycznej. Ukraina, pozbawiona ochrony wojskowej, staje się kolonią Imperium Rosyjskiego.

Prace nad filmem rozpoczęly się, gdy wojska hitlerowskie stały już na granicy z ZSRR, dlatego wyczuwalny jest w nim nastrój niepokoju. Film jakby modeluje charakter zbliżającej się wojny. Utalentowany przywódca wzywa do walki, prowadzi heroiczne i zwycięskie kampanie, wróg drży. Ukraińcy są nieustraszeni, w pogardzie mając śmierć, a jeśli trafiają do niewoli, dzielnie się tam trzymają. Takich odważnych ludzi widz miał pokochać, brać z nich przykład. Tortury, którym wrogowie poddają pojmanych Ukraińców, są zarazem znakiem radzieckiej rzeczywistości lat 30., czyli kaźni w lochach NKWD.

Film kręcono w bardzo trudnych warunkach. Ihor Sawczenko miał poczucie humoru, które pomagało mu $\mathrm{w}$ trudnych sytuacjach i poszerzało wąskie ramy schematyzmu. Reżyser wymagał od wszystkich aktorów pełnego zaangażowania, o czym świadczy następujące zdarzenie:

Były dni, gdy nie było czasu na odpoczynek. Aktorzy, jak prawdziwi wojownicy, nauczyli się spać na stojąco. Polski oficer (aktor Smirnow) przyjął pierwsze uderzenie Bohuna i jak skoszony padł na ziemię. Zakończono nagrywanie sceny, zabrzmiała komenda „Przerwa!”, a „zabity” nie wstawał. Zaniepokojeni asystenci reżysera pobiegli do aktora. Okazało się, że ten słodko śpi. Zmęczył się, biedny, po kilku nieprzespanych nocach zdjęć ${ }^{90}$.

Nieodłączną cechą reżyserii Ihora Sawczenki było łączenie spraw podniosłych i przyziemnych, epickości i komizmu. Sawczenko chciał nadać swemu filmowi epicki charakter, ale epickość nie wykluczała poczucia humoru (nośnikiem humoru

90 Ю. Колесниченко, „Богдану Хмельницькому” - 25 років, „Новини кіноекрану” 1966, nr 2, s. 12. 
ludowego byli Kozak Dowbnia i diak Hawryło, który nie był zwolennikiem łask niebiańskich, ale ziemskich przyjemności, amatorem okowity). Należało uczłowieczyć dość schematyczne postacie. Bohdan Chmielnicki, jak przystało na przywódcę, lubił płomienne przemówienia nastrajające lud do bohaterskich czynów; wygłaszał przy tym jedynie słuszne postulaty, np. „Na zawsze razem z narodem rosyjskim!”.

Pomimo schematyzmu i nadmiernego patosu militarnego, film Bohdan Chmielnicki ceniony jest jako dzieło, w którym po raz pierwszy od wielu lat pokazano ukraińską historię, Kozaków, i to nie w sposób zniekształcony czy karykaturalny (jak w ekranizacjach Gogola z lat 30.), lecz pozytywny, heroiczny. Dziś historycy kina, a nawet piszący o filmie polscy autorzy, zauważają duży profesjonalizm reżysera w kwestii filmowania bitew, rozwoju akcji czy pracy aktorów ${ }^{91}$. $\mathrm{Z}$ dużą wiarygodnością ukazano olbrzymi rozmach walk narodowowyzwoleńczych. W celu uwiarygodnienia przedstawianej epoki, reżyserowi udało się przekonać wpływowego autora scenariusza, żeby uzyskał pozwolenie na wykorzystanie zbiorów Muzeum Historycznego w Czernihowie, w którym zachowała się słynna kolekcja zbiorów kozackich zebrana przez Wasyla Tarnowskiego (kolekcja nie była eksponowana). Utalentowany scenograf Jakiw Riwosz zbudował na brzegu Dniepru wspaniałe dekoracje Siczy Zaporoskiej. Operator Jurij Jekelczyk zadbał, by na ekranie pojawiły się epickie obrazy z życia ludu; okazał się mistrzem portretu filmowego. Nadał on niezbędnego kolorytu szlachcie przedstawianej w filmie; przepych przyciągający wzrok, a jednocześnie - motyw jej duchowej słabości. Szczególnie wyraźnie widać to w scenie na zamku, kiedy Potocki (Dmytro Milutenko), pewny siebie i apodyktyczny, dowiaduje się o klęsce swego syna Stefana. Operator filmuje scenę z góry, pokazując małą sylwetkę Potockiego pośród ogromnej sali. Efekt optyczny zastosowano również w scenie egzekucji Kozaków nabijanych na pal. Drogę z Niżyna do Kijowa Stefan Potocki przekształcił w drogę śmierci. Pod stopami Kozaków płonął ogień. Ogniska rozpalono na znacznym odcinku, a kręcić zdecydowano się w momencie, gdy ogień i mężczyznę widać było na tej samej płaszczyźnie ${ }^{92}$.

Ważnym elementem filmu była muzyka. Kompozytor Serhij Potocki wykorzystał stare pieśni ukraińskie i dumy, polskie marsze i mazurki.

Bohdana Chmielnickiego zagrał rosyjski aktor Nikołaj Mordwinow. W niektórych scenach pokazał siłę charakteru i wybuchowy temperament ukraińskiego hetmana.

Jednak wśród ogółu nienawiści do wszystkiego, co polskie, przywiązanie Bohdana do katoliczki Heleny Czaplińskiej wyglądało na niesamowite dziwactwo. Chmielnicki nabiera odpowiedniego dystansu po odkryciu złodziejskich zamiarów Heleny i całkowicie oddaje się sprawie narodowej ${ }^{93}$.

91 J. Tazbir, op. cit.

92 Ю. Колесниченко, оp. cit., s. 12.

93 В. Токарев, op. cit. 
W filmie zauważalne są dwa bieguny: z jednej strony wojsko zaporoskie, z drugiej — polska szlachta i ukraińscy zdrajcy, którzy razem tworzą nieelegancki wizerunek Rzeczypospolitej i jej sojuszników. Każdy z aktorów w założonym nurcie portretował swoją postać: utalentowany Dmytro Milutenko - hetmana koronnego Potockiego, A. Davidson — księdza Łętowskiego, Haren Żukowska — damę Helenę Czaplińską, której aktorka użyczyła egzaltowanej nabożności i próżności. Apodyktycznego i przemądrzałego Stefana Potockiego oraz zarozumiałego dandysa Czaplińskiego grali niemieccy emigranci polityczni Heinrich Greif i Hans Klering. Filmowi Polacy w większości reprezentować musieli cechy negatywne.

Polityczna podszewka nadszarpniętego stereotypu, w oparciu o który Kornijczuk i Sawczenko stawiali Ukraińców ponad Polakami, była jasna dla części radzieckich widzów. (...) Od początku filmu widoczny jest kontrast między Polakami i Zaporożcami: zamknięte, ciemne kościoły i otwarte przestrzenie naddnieprowskiego stepu; zimny błysk stali, jedwab, złoto i ciepło prostego ubioru; kontrastujące, przyciemnione oświetlenie i naturalne, miękkie światło słoneczne; ujęcia z góry i kadrowanie z „normalnego” poziomu oczu, a często filmowanie z dołu uwydatniające wzrost człowieka. Film rekonstruował historię Chmielnicczyzny jako listę krzywd i zemstę na Polakach. Kornijczuk stworzył pewnego rodzaju kanon w pokazywaniu Bohdana Chmielnickiego, i kanon ten obecny był w sztuce przez długi czas ${ }^{94}$.

Film stanowi wzorzec kina historycznego w jego monumentalnym aspekcie. Wciąż jest interesujący dla historyków kina, przede wszystkim jako przykład mocnej reżyserii, która zadowalała władzę pod względem konceptualnym i profesjonalnym. Publiczność nie powinna mieć wątpliwości, że sensem życia ukraińskiego przywódcy, sensem wojny narodowowyzwoleńczej było zjednoczenie z Rosją.

\section{TEMATYKA POLSKA W KINIE USRR LAT 1945-1991}

Związek Radziecki zmienił nastawienie do Polski z negatywnego na pozytywne w trakcie II wojny światowej. Potwierdzają to fakty, które przytoczymy, powołując się na Ukraińska Encyklopedię Radziecka: w 1942 roku utworzono Polską Partię Robotniczą, która m.in. prowadziła działalność polegającą na organizowaniu walki zbrojnej przeciwko okupantom. 1 stycznia 1944 z inicjatywy PPR w Warszawie utworzono Krajową Radę Narodową - tymczasowy organ najwyższych władz z B. Bierutem na czele. W lecie 1944 roku Armia Radziecka razem z Wojskiem Polskim (utworzonym na terytorium ZSRR w 1943 roku) wkroczyła na ziemie polskie. 21 lipca 1944 roku powstał Polski Komitet Wyzwolenia Narodowego, który pełnił funkcje polskiego rządu na terenach wyzwolonych ${ }^{95}$. Kierując się maksymą „dziel i rządź” i z wykorzystaniem znanego już schematu, władza komunistyczna powtórzyła scenariusz zastosowany na Ukrainie na początku 1918 roku: podobnie jak

\section{Ibidem.}

95 Ю.В. Ілінич, Польщ̧а, УРЕ, t. 8, Київ 1982, s. 512. 
wtedy, na terytorium niezależnego kraju utworzyła lojalną względem siebie partię, rząd, armię i oświadczyła, że jest to „legalny rząd”. Żołnierzy Armii Krajowej określono mianem ,agentów emigracyjnego rządu polskiego”, za którymi naród polski nie poszedł, ale stanął po stronie wyżej wymienionych jednostek politycznych i wojskowych. W wyborach do Sejmu w 1947 roku zwyciężył „blok demokratyczny z PPR na czele". Rok później powstała Polska Zjednoczona Partia Robotnicza (PZPR), która odtąd rządziła krajem. Polska przystąpiła do obozu socjalistycznego i znalazła się pod protektoratem ZSRR.

Od zakończenia wojny aż do upadku Związku Radzieckiego tematyka polska w kinie ukraińskim jest niemal nieobecna. I to nie dlatego, że nie interesowano się sąsiednim krajem. Na Ukrainie tłumaczono polską literaturę, wyświetlano polskie filmy, słuchano polskich piosenek, na ukraińskiej estradzie pojawił się Pociąg $z$ Warszawy według tekstu Liny Kostenko, w teatrze $\mathrm{z}$ wielkim powodzeniem grano sztukę Warszawska melodia. Ukraińscy filmowcy nie zwracają się jednak ku polskiej rzeczywistości. Wśród przyczyn należy wymienić małą liczbę filmów kręconych w latach 1945-1955, problemy ukraińskiej literatury narodowej w czasach odwilży (połowa lat 50. - początek 70.), rusyfikację. Nie proponowano tej tematyki, a co ważniejsze - z polską rzeczywistością można było zetknąc się, oglądając polskie filmy, które wyświetlano w kinach USRR i ukraińskim filmowcom nie wypadało z nimi konkurować.

W okresie powojennym przemysł filmowy USRR, jak i cała gospodarka, były w rozsypce: w latach 1944-1952 wyprodukowano tylko 11 filmów fabularnych. Jeden z nich był filmem o Polsce, a dokładniej, o heroicznym Polaku. Zygmunt Kłosowski (scenariusz Ihor Łukowski, reżyseria Zygmunt Nawrocki i Borys Dmochowski, który grał postać tytułową, zdjęcia W. Firsow, muzyka O. Sandler, scenografia J. Riwosz, M. Sołocha, J. Hankin. Wytwórnia Filmowa w Kijowie, 1945) to film przygodowy opowiadający o walce Polaków z hitlerowskim najeźdźcą. Akcja rozgrywa się w okupowanej przez Niemców Polsce, gdy znany dziennikarz, były oficer polskiej armii, ucieka z niemieckiego więzienia. Prace nad filmem trwały, kiedy studio ewakuowano do Azji Środkowej, dlatego nie tylko wnętrza, ale również ulice i domy polskich miast były tworzone przez scenografów. Borys Dmochowski, radziecki aktor i reżyser, pracował w teatrach w Leningradzie. Podczas wojny występował w filmach, później grał głównie wojskowych w obrazach wytwórni kijowskiej. Do Zygmunta Kłosowskiego nastawiono się pozytywnie, o czym świadczy wpis w Stowniku kina:

Bohaterem filmu jest dziennikarz Gołęba podający się za inwalidę Grossa, barona Fedrucci, prokuratora Waliszewskiego, gestapowca Ultera. Każdą z tych postaci aktor obdarzył charakterystycznymi cechami, co świadczy o jego wielkim talencie ${ }^{96}$.

96 Дмоховский Б.М., [w:] Кинословарь в двух томах, t. 1, Москва 1966, s. 484. 
Jednak w drugim tomie Historii ukraińskiego kina radzieckiego, przeciwnie, podkreślano sztuczność, naciąganie sytuacji, niewiarygodność okoliczności, w których znalazł się bohater filmu. W scenariuszu Ihora Łukowskiego ${ }^{97}$

było wiele niesamowitych przygód, nieprawdopodobnych zbiegów okoliczności, dziwnych wydarzeń. Takie cechy są zupełnie naturalne dla filmów przygodowych (...). Reżyserów zdradza poczucie proporcji i poprawności artystycznej. Autorzy filmu zachwycają się spektakularnymi ucieczkami, pościgami, eksplozjami. (...) Pod koniec filmu główny bohater wciela się w niemieckiego żołnierza - inwalidę Grossa. Jednak wcześniej Gross tajemniczo znika, co nie mogło ujść uwadze gestapo. Nie przeszkadza to jednak bohaterowi przyjąć skompromitowane nazwisko, a nawet zakupić u niemieckiego oficera kilka karabinów maszynowych i skrzynek z granatami. Ta „komercyjna” operacja nie wywołuje u Niemca żadnych podejrzeń. (...) Tak samo łatwowierni i lekkomyślni są również pozostali wrogowie. (...) Zygmunt Kłosowski to człowiek wyjątkowy, samotny bohater, niezniszczalny, niezwyciężony ${ }^{98}$.

Film obejrzało ponad 18 mln widzów. Wpisał się on w oczekiwania masowego odbiorcy, który chciał zobaczyć na ekranie niezwyciężonego bohatera, a napięcie przeważyło nad nieprawdopodobieństwem zdarzeń.

W 1956 roku w Wytwórni Filmowej w Kijowie nakręcono kolorowy film Trzysta lat teти... w reżyserii Rosjanina Władimira Pietrowa (tego samego, który wyreżyserował Piotra I), według scenariusza Ołeksandra Kornijczuka. Teksty piosenek napisała Wanda Wasilewska. Była to gorsza wersja filmu Bohdan Chmielnicki, a przedstawiono w nim te same wydarzenia z XVII wieku. Film przygotowywano na 300. rocznicę zjednoczenia Ukrainy z Rosją (1954), ale reżyser, któremu zlecono to ważne ideologicznie zadanie, nie podołał wyzwaniu. Rozpoczętą już produkcję trzeba było ratować, zaproszono więc reżysera z Rosji. Historycy o filmie niemal zapomnieli.

$\mathrm{Z}$ tego względu, że filmów produkowano mało, na potrzeby widzów filmowano sztuki teatralne czołowych dramaturgów. Wśród nich znalazła się Moralność pani Dulskiej — komedia Gabrieli Zapolskiej, spektakl Kijowskiego Teatru Dramatu Rosyjskiego im. Łesi Ukrainki. (Scenariusz i reżyseria Leonid Warpachowski - Rosjanin pracujący wówczas w tym teatrze i Ołeksa Szwaczok, zdjęcia Serhij Rewenko, Wytwórnia Filmów Fabularnych w Kijowie, 1957). Rzecz dzieje się w rodzinie urzędnika Dulskiego. Syn Dulskiego, Zbyszek, uwiódł pokojówkę Hankę, która oczekuje teraz jego dziecka. Pani Dulska, matka dwóch córek, nie może dopuścić do skandalu i postanawia wygnać Hankę z domu. Jednak Zbyszek, pijak i rozpustnik, by dopiec matce, oświadcza, że ożeni się z Hanką. Energiczna pani Dulska dokłada wszelkich starań, by do tego nie dopuścić. Dziewczyna otrzymuje pieniądze i wraca na wieś. Zbyszek znów jest wolny, a rodzina szczęśliwa. Biednej

97 Igor Łukowski, rosyjski scenarzysta, jeszcze powróci do tematyki przygodowej. Na podstawie jego scenariusza z 1966 r. w Kijowie nakręcono film Ïх знали тільки в обличчя, który zyskał wielką popularność.

98 Історія украӥнського радянського кіно, t. 2, s. 179-180. 
Hance współczuje jedynie najmłodsza córka Dulskich, Mela. W sztuce występowali znani aktorzy: Jewhenija Opałowa, Wiktor Chałatow, Wira Predajewycz.

Dwadzieścia lat później na ekranach pojawił się jeszcze jeden polski utwór. Krakowiaków i górali, sztukę wystawioną na motywach opery Wojciecha Bogusławskiego, sfilmowano w Narodowym Teatrze Dramatycznym im. Iwana Franki w Kijowie (reżyseria A. Sawczenko i Serhij Smijan, zdjęcia A. Suski. Obsada: Wiktor Cymbalist, O. Szawarski, Hałyna Semenenko, Wołodymyr Dalski. Wytwórnia Ukrtelefilm, 1976).

Do tematyki polskiej kino ukraińskie powróci dopiero w czasach niepodległości.

\section{TEMATYKA POLSKA W KINEMATOGRAFII NIEPODLEGŁEJ UKRAINY}

Z nadejściem niezależności znika cenzura i znikają wytyczne ideologiczne. Jednak dla kina ukraińskiego nastają trudne czasy: gospodarka Ukrainy jest w bardzo złej kondycji, podobnie przemysł filmowy. Teatry są zamykane, widz ogląda głównie zagraniczne produkcje w telewizji i na wideo. W tych trudnych warunkach powstają, mimo wszystko, filmy fabularne i dokumentalne. Pojawiła się możliwość zastanowienia się nad przeszłością, nad okresem wspólnej polsko-ukraińskiej historii, nowego odczytania stosunków między dwoma sąsiadującymi ze sobą narodami. W powstawaniu filmów dokumentalnych aktywny udział brali historycy.

Jeden z filmów z serii Nieznana Ukraina (150 odcinków), nakręcony w latach 1992-1993 nosił tytuł Za wolność waszą i naszą (scenariusz Mychajło Rubinstein, reżyseria Łarysa Daszenko, zdjęcia Wołodymyr Pominow. Filmoteka Narodowa Ukrainy, 1993). To naukowo-edukacyjna opowieść o Polsce i Ukrainie w XIX wieku, kiedy oba kraje były częścią Imperium Rosyjskiego. Utrata niepodległości wiązała się z powstawaniem ruchów wyzwoleńczych. Opowiedziano o powstaniu listopadowym $\mathrm{z}$ lat 1830-1831. W 15-minutowym filmie wykorzystano fragmenty filmu fabularnego Taras Szewczenko I. Sawczenki, w którym pokazano rozmowę ukraińskiego poety z uczestnikami polskiego powstania.

W 2001 roku w polsko-ukraińskiej koprodukcji nakręcono film dokumentalny Bliscy a dalecy (scenariusz Anna Górna, Lubomir Zając, reżyseria Anna Górna, Lubomir Zając, Mychajło Tkaczuk, zdjęcia Lesław Skuza, muzyka Jurij Najenko. TVP2, Studio Filmowe Sambor w Warszawie, Wytwórnia Filmów Fabularnych im. O. Dowżenki, Wesełka sp. z o.o.). Polscy i ukraińscy uczeni, historycy, socjologowie Jerzy Giedroyć, Roman Szporliuk, Jerzy Kłoczowski, Jarosław Isajewicz, Natalia Jakowenko, Jarosław Hrycak, Zbigniew Wójcik, politolog Zbigniew Brzeziński, ambasadorowie Dmytro Pawłyczko i Jerzy Bar opowiadają o tysiącu lat historii stosunków między Ukrainą i Polską, a także o perspektywach rozwoju obu krajów. W filmie wykorzystano fragmenty filmów dokumentalnych Uratowane 
piękno, Pani senator, Zdobyć albo nie być, Rajskie wyspy hetmana Sahajdacznego. Fragmenty poematu Juliusza Słowackiego Beniowski czytał ukraiński aktor Witalij Rozstalnyj.

31 marca 2004 Studio Ukrkinochronika uwieczniło na taśmie filmowej ważne wydarzenie: Otwarcie Roku Polski na Ukrainie (reżyseria Zuzanna Szapowałowa, zdjęcia Wołodymyr Taranczenko i Bohdan Pidhirnyj). Inauguracja odbyła się w Ukraińskiej Operze Narodowej im. Tarasa Szewczenki, obecni byli Prezydent RP Aleksander Kwaśniewski i Prezydent Ukrainy Leonid Kuczma. Imprezę zorganizowano pod hasłem „Polska i Ukraina — razem we wspólnej Europie”.

Kolejnym filmem dokumentalnym, który zapisał się w annałach kinematografii ukraińskiej, jest obraz Złoty wrzesień. Kronika Galicji 1939-1941 (scenariusz i reżyseria Taras Chymycz, zdjęcia Lubomyr Sołomczenko, muzyka Adriana, Tercja Pikkardyjska. Obsada: Hałyna Daliawska, Jurij Chwostenko, Lew Reha, Wołodymyr Prawosudow, Natalia Lisowa. Invert pictures na zlecenie Zachodnioukraińskiego Centrum Badań Historycznych, 2010). W filmie przedstawiono wydarzenia, które rozegrały się na Zachodniej Ukrainie przed rozpoczęciem II wojny światowej, nastanie władzy radzieckiej, zmianę granic i znikanie całych państw z mapy świata. Film oparto na dokumentach archiwalnych, materiałach i wspomnieniach świadków, przedstawicieli ludności polskiej, ukraińskiej i żydowskiej przedwojennej Galicji, którzy do lat 40. XX wieku stanowili główny element etniczny tego regionu. Wykorzystano również kroniki filmowe oraz komentarze naukowców i badaczy.

Sześćdziesiąt lat po wejściu na ekrany obrazu Ihora Sawczenki ukraińscy filmowcy wrócili do postaci Bohdana Chmielnickiego. Prace nad eposem Bohdan Zenobiusz Chmielnicki trwały siedem lat (scenariusz Mykoła Maszczenko, Andrij Jaremczuk, reżyseria Mykoła Maszczenko, zdjęcia Serhij Bordeniuk, scenografia Witalij Jaśko, muzyka Mychajło Czemberdżi. Obsada: Wołodymyr Abazopulo (Chmielnicki), Denis Kokariow — car, Serhij Dżygurda — Jan Kazimierz, Bilal Bilałow - Islam Girej, Wiktor Kruczyna - Jeremi Wiśniowiecki oraz Mykoła Bokłan, Witalij Rozstalnyj, Lilia Kuzniecowa, Anatolij Czumaczenko, Irma Witowska, Taras Denysenko, Mychajło Konecznyj, Ostap Stupka, Georgij Chostikojew, Georgij Moroziuk, Serhij Romaniuk. Wytwórnia Filmów Fabularnych im. O. Dowżenki. Trzy wersje: pierwsza - 2005 rok, druga, $180 \mathrm{~min}-2007$, trzecia, 135 $\min$ - 2008).

Podjęcie się takiego zadania w okresie kryzysowym dla kinematografii ukraińskiej było szaleństwem. Ukraińskie komercyjne kanały telewizyjne pełną parą rozpoczęły produkcję programów rozrywkowych bardzo niskich lotów, a produkcję filmową dotowaną przez państwo hamowały problemy finansowe. Prace nad filmem wstrzymywała walka z biurokracją i szczegółowa weryfikacja dokumentacji, drakońskie warunki przetargowe, korupcja pracowników odpowiadających za przetargi; wydzielone na film z budżetu państwa fundusze nie nadchodziły wcale lub w ostatniej chwili i ich wykorzystanie było już niemożliwe. Film zaś wymagał 
ciężkiej pracy. Trzeba było ubrać i wyposażyć 30 tys. żołnierzy (ukraińskich, polskich, tatarskich), zarządzać nimi w scenach bitew. Tysiące sztuk kostiumów, broni, koni, wyposażenie wnętrz. Nakręcenie tego filmu przez Mykołę Maszczenkę można rozpatrywać w kategoriach wyczynu.

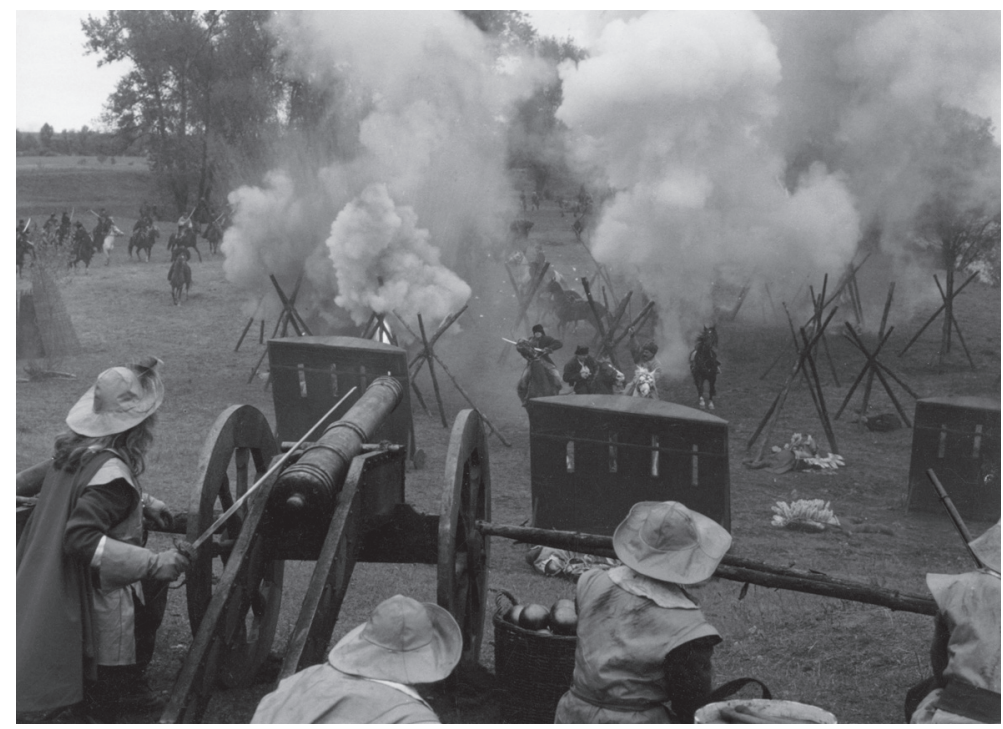

6. Bitwa Kozaków z polskimi wojskami. Kadr z filmu Bohdan Zenobi Chmielnicki. Reż. Mykoła Maszczenko, Kijowska Wytwórnia Filmowa im. O. Dowżenki, 2008

Film był realizowany przez pasjonatów. Mykoła Maszczenko to reżyser inspirujący każdego, kto z nim pracuje. Doświadczony, energiczny, romantyk. Chmielnickiego i jego walkę o wolność narodu ukraińskiego ukazał w sposób nieco patetyczny. Maszczenko przymierzał się do tego filmu jeszcze w 1990 roku, chcąc nakręcić serial telewizyjny (miał już doświadczenie, w latach 80. nakręcił w Bułgarii serial Droga do Sofii); napisał scenariusz przewidujący 24 odcinki. Jednak projekt upadł, zaczęły się więc zdjęcia do wersji kinowej. W 2000 roku pojawiły się fundusze na ubiory historyczne; zaangażowano jazdę, choć na Ukrainie nie było już koni, które grałyby w filmach, tak więc reżyser musiał przejść etap szkolenia konnicy. Ministerstwo Obrony do udziału w filmie oddelegowało wojsko. Jednak kolejna zmiana rządu doprowadziła do zahamowania procesu produkcji. Z powodu trudności finansowych prace ciągnęły się przez siedem lat, kolejny rok przeznaczono na skrócenie gotowej już wersji i nagranie dźwięku w formacie Dolby. Reżyser zakończył „epopeję produkcyjną” wbrew niesprzyjającym okolicznościom. Problemy nie ostudziły temperamentu reżysera, co jest szczególnie widoczne w scenach batalistycznych, genialnie sfilmowanych przez operatora Serhija Bordeniuka. 
Co nowego można powiedzieć o jednej z kluczowych postaci ukraińskiej historii? Hetman Bohdan Chmielnicki to zwycięski przywódca, budowniczy Państwa Kozackiego (Hetmanatu). Nastawienie do Chmielnickiego nie jest jednoznaczne. Wyrwawszy Ukrainę z jednego zniewolenia, nieopacznie pchnął ją w inne. Nie miał daru jasnowidzenia, by przewidzieć tragiczne konsekwencje ugody perejasławskiej z 1654 roku. Nie była to jednak wina tylko Bohdana, ale też jego następców, lecz to zupełnie odrębny temat.

Maszczenko koncentruje się na sukcesach dowódcy, jednak chce również odbrązowić Chmielnickiego, poza polem bitwy pokazując człowieka nie do końca szczęśliwego, próbując przeniknąć do jego życia prywatnego, zrozumieć swego bohatera i targające nim wewnętrzne sprzeczności. Talent wojownika splatał się z problemami człowieka. Nowością w postrzeganiu Chmielnickiego jest niejednoznaczność tego obrazu.

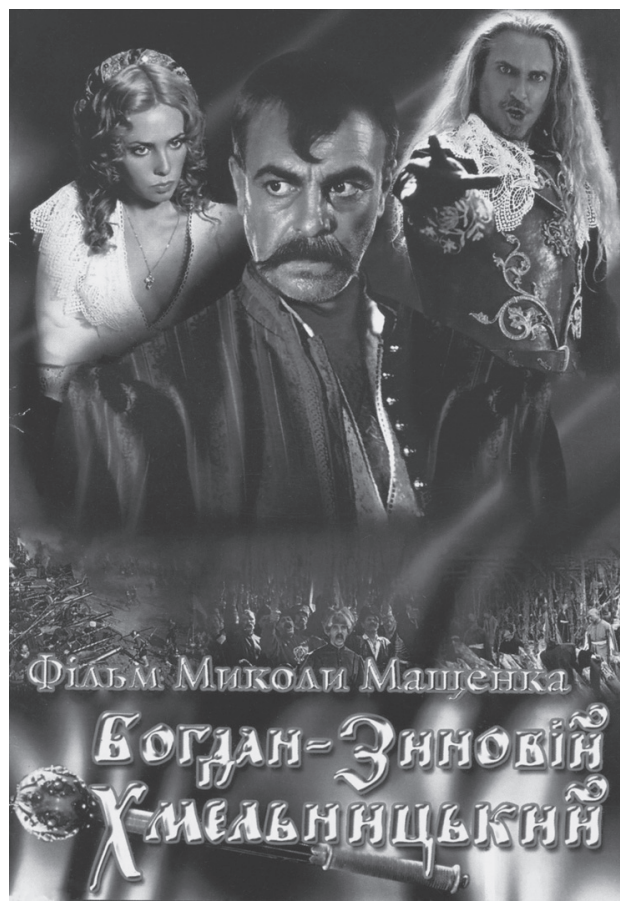

7. Plakat filmu Bohdan Zenobi Chmielnicki

W filmie Maszczenki dominują emocje. Dodajmy do tego duże nagromadzenie materiału historycznego, który, co często zdarza się w filmach historycznych, przeszkadza w ukazaniu wiarygodnego bohatera lub po prostu sprowadza ekranizację do roli ilustrowania wydarzeń. Niedociągnięcia te występują również i tutaj. Niemniej jednak nie wpłynęły one znacząco na odbiór filmu. Filmowcy przeniknęli 
przez stulecia i przybliżyli widzowi żywego człowieka. Wołodymyrowi Abazopulo, aktorowi teatralnemu, który zagrał głównego bohatera, tak duża rola przypadła po raz pierwszy. Wybór był trafny. Aktor sprawia, że Chmielnicki jest postacią wiarygodną. Wyczuwalna jest siła wyjątkowej osobowości z jej niepohamowanymi emocjami. Widać to podczas sceny narady pułkowników: jeszcze chwila i podniesiona szabla odcięłaby głowę nieposłusznemu pułkownikowi. Bohdan wstrzymał szablę w ostatnim momencie. Reżyser wyraźnie sympatyzuje z Chmielnickim i jest to zrozumiałe. Chmielnicki nie oszczędza się dla dobra sprawy. Prowadzi swe pułki do walki, bitwy są jego żywiołem. To specjalnie akcentowane punkty kulminacyjne, które pod względem formy i kolorystyki, zestawienia kolorów kostiumów i rozwiązań kompozycyjno-przestrzennych nieco przypominają bitwy z filmu Kurosawy Ran. Pomimo brutalności widowiska, w którym padają konie i jeźdźcy, pomimo strzelaniny i walk wręcz, oplata je aura uroczystości. Oczywiście, retoryka wizualna, a więc sceny batalistyczne z wybuchami, efektami pirotechnicznymi, kaskaderami, pożarami, zabitymi, którzy padają razem z końmi, była obecna w filmach wiele razy. Według Łukasza Jasiny „niewątpliwą zaletą filmu jest pozbieranie w nim w jednym miejscu wszelkiego rodzaju klisz i stereotypów wytworzonych przez kino radzieckie, amerykańskie i zachodnioeuropejskie" 99 . Jednak tam galopowali i walczyli inni wojownicy, a tu mamy naszych ukraińskich rycerzy.

Chmielnicki-dowódca wymaga od swych podwładnych poddania się jego woli. Jest niewzruszony, pewny siebie, wierzy w zwycięstwo. Jego cechy narodowe, charakter ukraińskiego przywódcy, przejawiają się przede wszystkim w nieumiejętności wykorzystania owoców swoich zwycięstw. Chmielnicki jest miłosierny dla polskiego króla, z którym dopiero co walczył. Wydaje polecenie odprowadzenia go bez szwanku do Warszawy. Wielkoduszność zwycięzcy świadczy, że jest człowiekiem szlachetnym. Jednocześnie, czy tego chce, czy też nie, nie jest w stanie przewidzieć konsekwencji takiego kroku: Jan Kazimierz przekupuje bowiem jego sojusznika chana Tatarów Gireja. W ten oto sposób utalentowany wojownik, który pokazuje siłę w otwartej walce, jest bezsilny wobec zdrady.

Pełen temperamentu Mykyta Dżygurda nie szczędzi wyrazistych cech granemu przez siebie królowi Janowi Kazimierzowi: najpierw król żyje iluzją o niezwyciężoności swych wojsk, a potem, nie zważając na niebezpieczeństwo, na próżno próbuje powstrzymać tych, którzy uciekają z pola bitwy, by ostatecznie, doznawszy porażki, z wykrzywionym w bezsilnej wściekłości obliczem przyjąć łaskę swego wroga. Aktor ujawnia swój temperament także w innych scenach, np. tej, w której król dyktuje do chana krymskiego list pełen obietnic bez pokrycia, byleby za wszelką cenę zerwać sojusz Chmielnickiego i Gireja, a przynosi to efekty w bitwie pod Beresteczkiem.

99 Ł. Jasina, O kilku ukraińskich filmach historycznych, http://www.psz.p1/99-film/lukasz-jasinao-kilku-ukrainskich-filmach-historycznych. 
Dużo uwagi poświęcono księciu Jeremiemu Wiśniowieckiemu (w tej roli Wiktor Kruczyna, również debiutant). W historii i pamięci narodu ukraińskiego Jarema zapisał się jako kat (wcześniej przytoczono słowa Natalii Jakowenko na ten temat). W filmie Maszczenki Wiśniowiecki nie jest postacią jednoznacznie negatywną: to młody mężczyzna kochający swoją żonę, syna, fanatycznie oddany Polsce, na którą „buntownicy” podnieśli rękę. Kruczyna z wielkim talentem oddał chorobliwie pojmowany honor, który nie pozwala Wiśniowieckiemu przyjąć warunków Chmielnickiego i poddać się, choć otoczeni w jego twierdzy ludzie umierają z głodu; szlachta chce, by zaakceptował żądania Kozaków i skapitulował. Otoczonych w twierdzy obrońców reżyser nie pokazuje jednak jako głodnych i wyczerpanych. Przeciwnie, wytwornie ubrani zjawiają się na balu. Trudno uwierzyć, że ci ludzie są w tarapatach. Mistrzowsko zagrany pojedynek na szable między księciem Wiśniowieckim i legendarnym Kozakiem Morozenką ${ }^{100}$ (Taras Denysenko) przynosi spektakularny efekt. By widz nie zmiłował się nad Wiśniowieckim, reżyser wprowadza do filmu jego spotkanie z ukraińskimi rzemieślnikami robiącymi kobzy. Czy może być coś bardziej odrażającego od osoby o takiej pozycji, która własnoręcznie karze nieuzbrojonego, niewinnego człowieka! Wiśniowiecki zabija mężczyznę, niszczy instrument. Scena ta pokazała przyczynę sprzeciwu, który przerodził się w wojnę narodowowyzwoleńczą o ogromnej skali.

Sukcesom wojskowym ukraińskiego dowódcy nie nadano, niestety, należnej dramaturgii. Film tego rodzaju powinien mieć jasno określone przesłanie. Maszczenko trzyma się faktów historycznych. Szczegółowo przedstawił oblężenie Polaków w Zbarażu, bitwę pod Zborowem, ale fabuła nie jest rozbudowana. Zaletą filmu jest akcja. Napięcie tworzą głównie sceny batalistyczne: kamera operatora Serhija Bordeniuka nurkuje w tysięczne masy, lawirując pomiędzy kopytami końskimi, rzucając widza w wir walki. Była do tego potrzebna spora doza energii twórczej.

W filmie zabrakło bitwy pod Beresteczkiem, etapu tworzenia państwa. Aby zachować kruchy, ale potrzebny narodowi pokój, Chmielnicki był zmuszony zgodzić się na warunki przeciwnika. Rządy Chmielnickiego w czasie pokoju pokazano fragmentarycznie, w pamięć zapada jedynie scena audiencji ambasadorów różnych krajów i stwierdzenie Hetmana, że wkrótce będą oni mówić po ukraińsku. Chmielnicki zrobił wiele dla ustroju państwa: utworzył formację, którą oficjalnie nazwano Wojskiem Zaporoskim. Struktura administracyjna wywodziła się z kozackiej organizacji wojskowej, dlatego ziemie ukraińskie po obu stronach Dniepru kontrolowane przez Chmielnickiego zostały podzielone na pułki, a dowództwo wojskowe starszyzny kozackiej pełniło funkcję centralnej władzy wykonawczej popierającej Hetmana.

100 Postać historyczna: pułkownik Stanisław Mrozowicki zginął w jednej z bitew podczas szturmu twierdzy i już jako o Morozence śpiewano o nim w jednej z najbardziej poetyckich dum cyklu kozackiego. 
Wątek życia osobistego hetmana jest dość monotonny. Dowiadujemy się, że piękna wdowa, Hanna Zołotarenko, dogląda dzieci Chmielnickiego i jego pierwszej, zmarłej już żony, a on jest jej za to szczerze wdzięczny ${ }^{101}$. $Z$ jakiegoś powodu to właśnie ona przekazuje mu list od Heleny. Następnie Hanna znika z filmu. Helena z Czaplińskim znalazła się w niewoli kozackiej. Podczas burzliwego spotkania ze swym wrogiem Czaplińskim Chmielnicki okazuje łaskę — nie zabija bezbronnego, nawet jeśli ten człowiek zrujnował jego majątek. Pomimo faktu, że parę tę pojmano podczas ucieczki, Helena wygląda imponująco: w luksusowej sukni i biżuterii — by choć wyglądem oczarować groźnego wojownika. Obwieszona kosztownościami, mami go swoją miłością, używa gładkich słówek, wiedząc, że najpotężniejszą bronią w zdobywaniu mężczyzn jest pochlebstwo. Chmielnicki jest łatwowierny, jak u Puszkina, „сам обманываться рад”. Pomimo swej ślepej miłości, hetman zleca synowi Tymoszowi nadzór nad Heleną podczas jego nieobecności. Ten nie musi długo czekać — przyłapuje Helenę z przystojnym młodzieńcem. Ręka Tymosza nie zadrżała w akcie zemsty. Zdradę Heleny wyjaśniła Lina Kostenko w powieści Beresteczko ustami samego Chmielnickiego: czy wrażliwa na cielesne rozkosze piękna kobieta, mogła być wierną mężczyźnie, który jest ciągle na wojnie?

Prowadzenie bitew przychodzi Chmielnickiemu łatwiej niż bycie przewodnikiem swego narodu w czasach pokoju, gdy wokół pełno intryg, kiedy nikomu nie można ufać; sojusznicy drżą, a ukochanej kobiety nie można być pewnym. Dziś zwycięstwa i sukcesy, jutro - klęska i utrata zdobyczy wojennych.

Film trzyma w napięciu nie ze względu na ukazanie w nim sytuacji konfliktowych, lecz raczej dzięki wyrażaniu aktorskich emocji, dynamice i ruchowi mas ludzkich w kadrze (warte uwagi są sceny z Wiśniowieckim i Morozenką, wybuchy gniewu Chmielnickiego). Widzowie zobaczyli nie tylko wydarzenia z połowy XVII wieku, ale też możliwości Wytwórni im. O. Dowżenki. Mykoła Maszczenko, pomimo pewnych sprzeczności i odejścia od faktów historycznych, przeniósł na ekran dramaturgię działań wojennych.

Choć bohaterem filmów Ihora Sawczenki i Mykoły Maszczenki jest ta sama osoba, to różnice między oboma obrazami są znaczące: dla Ihora Sawczenki osiągnięciem było już samo pokazanie na ekranie historii Ukrainy, jednak wydarzenia interpretował zgodnie ze swoim widzimisię. Historię odtworzono w fakturze świata materialnego, zwyczajach, które obowiązywały na Siczy Zaporoskiej i kozackim męstwie; ideologia nie do końca rzuciła cień na wydarzenia i postacie. Zapewniło to filmowi długie życie, bez względu na kanony ówczesnego kina „biograficznego”.

Koncepcję Maszczenki warunkował wybór wydarzeń wojny narodowowyzwoleńczej. Aktualność jego filmu zasadza się na potrzebie obrony niezależności Ukrainy, która nie jest jednak darowana, ponieważ w walce przelano za nią dużo

101 Hanna Zołotarenko została wdową, a po śmierci żony Chmielnickiego opiekowała się jego dziećmi, po pewnym czasie pobrali się. 
krwi. O ile Sawczenko rzetelnie pokazał przyczyny wybuchu wojny i jej etapy, o tyle Maszczenko, kręcąc wielkie sceny zbiorowe, skoncentrował się na talencie dowódcy i zwycięstwach militarnych Chmielnickiego pod Zbarażem i Zborowem. Maszczenko pokazał Helenę, podkreślając luksusy ubioru, choć nie wiązało się to w dużym stopniu z realiami wojny.

Sytuację komplikował fakt, że Maszczenko nakręcił swego Bohdana Chmielnickiego jako drugi, a to wywołuje u historyków kina chęć porównywania go z filmem poprzednim. Maszczenko przedstawił spójną postać głównego bohatera, zarówno jego zwycięstwa, jak i porażki. O ile pierwsza część została skonstruowana i sfilmowana z uczuciem, o tyle już zakończenie, kiedy Chmielnickiemu przychodzi się kajać i posypywać głowę popiołem, wypadło mniej naturalne. Wydarzenia w filmie opowiedzieć można za jednym zamachem jedynie wówczas, kiedy i sam obraz kręcony jest na jednym oddechu, a nie kiedy prace trwają siedem lat.

Wojny kozackie i ich konsekwencje to niewyczerpane źródło tematów dla filmowców. Dzieło Maszczenki zostało w Polsce poddane ostrej krytyce. Łukasz Jasina stwierdza, że w przeciwieństwie do polskiego filmu Ogniem i mieczem, w którym kwestie polsko-ukraińskie przedstawiono szczególnie obiektywnie, film Mykoły Maszczenki jest pozbawiony logicznego związku z historią ${ }^{102}$. Nie można zgodzić się z tym stwierdzeniem, ponieważ, po pierwsze, zarzutu tego nie uzasadniono, a po drugie, porównywanie wytworu kultury z logiką i obiektywizmem interpretacji historii jest rzeczą niewdzięczną, gdyż, w przeciwieństwie do prac naukowych, twórczość jest zawsze subiektywna. Można mówić o tym, w jakim stopniu reżyserowi i scenarzyście udało się przekonać publiczność do swej wersji. Jasina pisze, że przeciwnikiem Chmielnickiego jest mitologizowany książę Jeremi Wiśniowiecki. Jednak takie właśnie jest kino - mitologizuje postaci historyczne. Jasina stwierdza również, że związki Bohdana Chmielnickiego z Europą Zachodnią to fakt mało prawdopodobny. Powołuje się przy tym na dwie publikacje — polską i ukraińską (Ю. Федорук, Міжнародна дипломатія і політика України. 1654-1657, Львів 1996). W rzeczywistości ostatnie trzy lata życia Chmielnickiego były pełne intensywnych kontaktów z europejskimi dyplomatami. Jeśli rozważać jego biografię szerzej, należy przytoczyć kilka faktów dobrze znanych na Ukrainie: Chmielnicki

w 1638 roku ponownie przebywał w Wilnie i Warszawie, gdzie starał się wymusić ustępstwa na polskim rządzie. Według niektórych danych, w 1644 roku Chmielnicki prowadził w Warszawie rozmowy z ambasadorem Francji, hrabią de Bregy, dotyczące warunków wciągnięcia do służby francuskiej 2600 Kozaków. W kwietniu 1645 roku odwiedził Francję, gdzie podpisał stosowną umowę. Kozacy wzięli później udział w działaniach wojennych przeciwko hiszpańskim Habsburgom pod Dunkierką ${ }^{103}$.

102 Ł. Jasina, op. cit.

103 Р.М. Шуст, Хмельницький Богдан-Зіновій Михайлович, [w:] Українське козаџтво. Мала енцииклопедія, Київ-Запоріжжя 2002, s. 510. 
Inny badacz pisze: „Pod koniec wojny trzydziestoletniej, w latach 1645-1646 korpus kozacki w służbie armii francuskiej pod dowództwem Bohdana Chmielnickiego, wchodzący w skład wojsk księcia Kondeusza, uczestniczył w oblężeniu i szturmie Dunkierki"104. Historyk Natalia Polonska-Wasyłenko tak ocenia talent dyplomatyczny ukraińskiego hetmana:

Ugoda perejasławska, sojusz wojskowy, który pokazał całemu światu niezależność Ukrainy od Polski, była kulminacją talentów dyplomatycznych Chmielnickiego. Ostatnie trzy lata życia hetmana charakteryzują się szczególnie intensywną działalnością dyplomatyczną ${ }^{105}$.

Zabiegi dyplomatyczne hetmana mające na celu poszukiwania sposobu na wyjście z sytuacji na początku lat 50. XVII wieku dokładnie przeanalizowała Natalia Jakowenko we wspominanej już pracy. Aktywna działalność dyplomatyczna Chmielnickiego była dość ostrożnym manewrowaniem między trzema mocarstwami - Rzecząpospolitą, Turcją i Moskwą. Ta ostatnia ceniła Kozaków zaporoskich, którzy strzegli przed zagonami tatarskimi nie tylko polskich, lecz także moskiewskich rubieży. Na porozumienie z dworem cara-jednowiercy nalegali również hierarchowie prawosławni, powodowani zaostrzeniem konfliktu w Rzeczypospolitej pomiędzy prawosławiem i unitami. Niestety, porozumienie polsko-ukraińskie przekreśliła wzajemnie przelana krew. Chmielnicki deklarował wieczny sojusz z carem, jednak zamiast niego zawarł umowę zbrojną podyktowaną konkretną sytuacją. Ludność Ukrainy przyjęła ją pozytywnie, ale było to złudzenie ratunku od trudów wojny. W umowie z Moskwą chodziło o poszerzenie protektoratu władcy silniejszego państwa nad słabszym.

Nie będziemy dyskutować o wartości artystycznej filmu Maszczenki, ponieważ postrzeganie i ocena, jak już wcześniej zauważyliśmy, to sprawa subiektywna, a nie jest to naszym zadaniem. Jednak stwierdzenia Łukasza Jasiny, że film jest szkodliwy, że autorzy „wykonują (nie wiadomo na ile szczerze i w sposób zamierzony) pewien gest wobec naszej wspólnej historii. Kozacy są w ich filmie częścią Rzeczypospolitej, buntują się przeciwko ciemiężącej, ale prawowitej władzy"106, że „film Maszczenki to z lekka zreformowana antypolska wizja dziejów”"107 — nie odpowiadają rzeczywistości. Wnioski te przypominają oburzenie rosyjskiego krytyka Walerija Kiczina wobec tego, jak przedstawiono cara Piotra I w filmie Modlitwa za hetmana Mazepe Jurija Illienki.

Historia jest sprawą niebezpieczną; aby ocenić prezentację wydarzeń historycznych w filmie, należy je poznać. Zdając sobie sprawę, że argumentacja współczesnych ukraińskich historyków może nie zadowolić Łukasza Jasiny, powołamy się

104 О. Апанович, Світова велич Богдан, [w:] Олена Апанович. Розповіді про запорозьких козаків, Київ 1991, s. 154.

105 Н. Полонська-Василенко, Історія України, t. 2, Київ 1992, s. 34.

106 Ł. Jasina, op. cit.

107 Ibidem. 
na pracę, która należy do najlepszych przykładów zachodniej literatury politycznej XVII wieku dotyczącej Rzeczypospolitej, na Traktat o Królestwie Polskim Jeana de Laboureura. Opisano w nim krótkowzroczną politykę Rzeczypospolitej. „Dużą uwagę przywiązywano do Kozaków jako do jednego z najważniejszych zjawisk i problemów tego państwa". W traktacie jest mowa o powstaniach kozackich końca XVI oraz pierwszej połowy XVII wieku, które, zdaniem autora, były odpowiedzią na pragnienia rządu polskiego do ustanowienia nad nimi swej kontroli. Autor z dezaprobatą pisze o brutalnych represjach, którym poddano Kozaków po klęsce powstania z lat 1637-1638. Król Polski po ostatnim powstaniu postanowił zgnębić Kozaków, tworząc w ich miejsce wojsko przygraniczne i zlecił tę sprawę hetmanowi Potockiemu; jeśli chodzi o Kozaków, to część z nich udała się do Moskwy, inni — do Chanatu Krymskiego. Wydarzenia te de Laboureur ocenił jako poważny błąd, który doprowadzi do osłabienia potęgi militarnej i chwały królestwa: „W ten sposób ta siła militarna, która przyniosła tyle sławy królestwu, która nic je nie kosztowała i broniła przed Tatarami, została prawie całkowicie zniszczona, a nowe wojsko, które ją zastąpiło, nie tak szybko stanie się prawdziwymi Kozakami"108. De Laboureura nie można podejrzewać o stronniczość i nastroje antypolskie. Jego przewidywania, że nowe wojsko „nie tak szybko stanie się prawdziwymi Kozakami” nie sprawdziło się, ponieważ wojsko zaporoskie dość szybko się odrodziło. O jego zwycięstwach i męstwie jest mowa — niechby i w niedoskonałym języku kina w filmie Mykoły Maszczenki, jego ostatnim dziele.

$\mathrm{W}$ bitwie pod Zbarażem rozbite polskie wojsko ratuje się ucieczką. W tym momencie Chmielnicki pochyla głowę przed królem, całuje go w rękę... Bohdan Chmielnicki, jak pisze Norman Davies, ,,doprowadził Kozaków i Tatarów aż do Wisły (...). W powstaniu tym zjednoczył się chłopski gniew i rzeczywiste niesprawiedliwości społeczno-polityczne i religijne wschodnich prowincji" ${ }^{109}$. Dobrze wiemy, co się stało później z Ukrainą i Polską: dziesięć lat po śmierci Bohdana Chmielnickiego Rzeczpospolita była zmuszona zgodzić się na rozejm andruszowski, na mocy którego utraciła Kijów i Lewobrzeżną Ukrainę na rzecz Rosjan. „Polska upadła i nas przygniotła...", jak napisał Taras Szewczenko.

Historyk i pisarz Walerij Szewczuk przyczynę błędu Chmielnickiego upatruje w tym, że jego prośby każda ze stron interpretowała na swój sposób:

...Rosjanie traktowali je jako określenie granic łaski carskiej, a nie jak umowę międzypaństwową lub, precyzyjniej, warunki carskiej protekcji, na mocy których przyłączają oni Sicz do swego państwa. Na tym poziomie między Ukraińcami i Rosjanami powstało wiele nieporozumień. Ukraińcy przyzwyczajeni do europejskiego systemu prawnego pojmowali umowę w europejskim znaczeniu tego słowa, natomiast Rosjanie mieli w tej kwestii swoje zdanie; przecież

108 Д.С. Наливайко, Західна рефлексія щзодо участі козаків у боротьбі з католицькою та польсько-иляхетською експансією, [w:] Історія украӥнського козачтва..., t. 2, s. 243-244.

109 Н. Дейвіс, Iсторія. Свропа, пер. $з$ англ., Київ 2001, s. 573, tłum. Р.J. 
obowiązywał tam nie system prawny, lecz wola cara (...). Wielki błąd Chmielnickiego polegał na tym, że zlekceważył on wszystkie te fakty ${ }^{110}$.

\title{
TRAGEDIA UKRAINY I POLSKI PODCZAS II WOJNY ŚWIATOWEJ I JEJ WSPÓŁCZESNA INTERPRETACJA
}

\begin{abstract}
Dwa sąsiadujące ze sobą narody, które walczyły o tę samą ziemię, w zasadzie nie mogą mieć takiej samej wizji przeszłości. Będzie tak przynajmniej dopóty, dopóki istnieje tradycja własnej historii narodowej. W odbiorze konfliktu zbrojnego podczas II wojny światowej współcześnie żyjących Polaków i Ukraińców może połączyć jedynie negatywny stosunek do zbrodni wojennych i zbrodni przeciwko ludzkości, niezależnie od tego, kto je popełnił.
\end{abstract}

Klymentij Fedewycz

Marc Ferro, historyk i badacz kina, stwierdza: „Doświadczenia wielu współczesnych twórców kina, zarówno tych, którzy pracują nad filmami fabularnymi, jak i innych, pokazują, że dzięki pamięci narodowej i tradycji ustnej filmowiec-historyk może przywrócić społeczeństwu historię, której go pozbawił porządek instytucjonalny" ${ }^{111}$. Rzeczywiście, filmowcy pracujący nad materiałem z historii Ukrainy, utrwalając na taśmie świadków wydarzeń, wypełniają ważną misję: oddają społeczeństwu jego przeszłość zakazaną w czasach sowieckich.

Swego rodzaju wprowadzeniem do wyjaśnienia konfliktu zaistniałego między Ukraińcami i Polakami w okresie międzywojennym był film dokumentalny Bereza Kartuska nakręcony przez Kanadyjczyka ukraińskiego pochodzenia Jurija Łuhowego. Na początek jednak kilka słów o sytuacji geopolitycznej. Ukrainę podzielono między kilka państw: większość jej terytorium znalazła się pod panowaniem radzieckim, Galicja i Wołyń weszły w skład Polski, Bukowina zaś - Rumunii. Walka Ukraińców o utworzenie suwerennego państwa ukraińskiego trwa nadal. W 1929 roku na I Kongresie Ukraińskich Nacjonalistów w Wiedniu powołano do życia Organizację Ukraińskich Nacjonalistów (jej przewodniczący Jewhen Konowałec zginął w 1938 roku z rąk agenta NKWD). Według historyków, na program i charakter polityki OUN wielki wpływ miało przekonanie, że za niepowodzenia działań wyzwoleńczych odpowiadają ukraińskie partie socjalistyczne i że demokracja nie zdaje egzaminu w warunkach walki narodu o niepodległość ${ }^{112}$.

110 В. Шевчук, Козацька держава. Етюди до історії українського державотворення, Київ 1995, s. 74.

111 M. Ferro, Kino i historia, Warszawa 2011.

112 М. Прокоп, Організація Украӥнських наџіоналістів, [w:] Енцикллопедія Украӥнознавства, t. 5, Нью-Йорк-Париж, 1966, s. 1863. 
Pamiętając o dominacji polskich elit przed wojną, zawiedzeni klęską sojuszu z Polską, zdradzeni w Rydze i niezadowoleni z codziennych doświadczeń z polskimi władzami, ukraińscy nacjonaliści upatrywali w Polsce największego wroga sprawy ukraińskiej. (...) Wrogość OUN wobec Polski wyrosła na gruncie politycznym: Galicję włączono do Polski, a galicyjscy Ukraińcy zostali obywatelami polskimi. Impulsem do powstania OUN był udział ukraińskich partii z Galicji w polskich wyborach w 1928 roku, które, pomimo pełnego ich odrzucenia przez ukraińskich nacjonalistów, legitymizowały porządek istniejących granic ${ }^{113}$.

W latach 30. XX wieku OUN staje się najaktywniejszą ukraińską siłą polityczną na Zachodniej Ukrainie i na emigracji; zaczyna też uciekać się do terroru. Konsekwencją tych działań są aresztowania członków OUN i jeszcze większa dyskryminacja ludności ukraińskiej.

OUN nie była ruchem powszechnym w międzywojennym państwie polskim, ale to ono stworzyło warunki dla wzrostu atrakcyjności OUN jako alternatywy dla niezadowolonych młodych wykształconych Ukraińców. (...) Pod koniec lat 1930-ych, po śmierci Piłsudskiego, państwo polskie z jeszcze większą gorliwością zwróciło się ku polityce „,narodowej asymilacji”. Gwałtowna pacyfikacja, publiczne pobicia i palenie cerkwi pomogły OUN szerzyć wizję zbliżającej się wojny między narodami ${ }^{114}$

— pisze współczesny historyk.

Bereza Kartuska (scenariusz Jurij Łuhowyj, Oksana Rozumna, zdjęcia i reżyseria Jurij Łuhowyj, narrator Bohdan Beniuk, muzyka Roman Łuhowyj. La Maison de Montage Lugovy Inc. Kanada, Montreal, 2007) to film opowiadający o przyczynach, które doprowadziły do wzajemnej wrogości pomiędzy Ukraińcami i Polakami, o dyskryminacji rdzennych mieszkańców Wołynia i Galicji przez władze polskie. Tytuł filmu przywodzi na myśl niesławne polskie więzienie usytuowane w miejscowości Bereza Kartuska (obecnie południowa Białoruś). W jego murach przebywali głównie Ukraińcy, oddani patrioci swej ojczyzny. Bohaterami filmu są mieszkańcy Galicji, którzy po II wojnie światowej wyemigrowali do Kanady; nawet teraz doświadczenia z wczesnej młodości są powodem do wzruszeń — daje się to odczuć, kiedy opowiadają o ucisku i pacyfikacji, o ich sprzeciwie wobec działań władz polskich. Polonizacja oznaczała kres wszystkiego co ukraińskie: szkół, cerkwi, działań twórczych. Przytoczone liczby są porażające: zamknięto wiele cerkwi prawosławnych; w porównaniu do czasów monarchii austro-węgierskiej ponad trzykrotnie zmalała liczba ukraińskich szkół. Pacyfikacja to już niszczenie ośrodków ukraińskich, a skutki pogromów utrwalono na zdjęciach. Polityka narodowa ówczesnych władz polskich była mizerna.

Film w dużym stopniu wyjaśnił przyczyny tragedii na Wołyniu, krwawych starć pomiędzy ukraińskimi i polskimi siłami zbrojnymi w czasie II wojny światowej i pierwszych latach powojennych, które, zamiast wspólnie stanąć przeciw-

113 Т. Снайдер, Перетворення націй. Польщза, Украӥна, Литва, Білорусь 1569-1999, пер. 3 англ., Київ 2014, s. 177-178.

114 Ibidem, s. 185. 
ko nazistowskiej i bolszewickiej inwazji, walczyły między sobą. Armia Krajowa walczyła z UPA, obie formacje brutalnie rozprawiały się z pokojowo nastawioną ludnością. Akcje odwetowe były organizowane niemal w każdej wołyńskiej wsi, gdzie żyli Ukraińcy lub Polacy.

Wydarzenia przedstawione w filmie komentują profesor Taras Hunczak z Rutgers University (USA), profesor Jarosław Rozumnyj z University of Manitoba (Kanada), a także polski historyk Wysocki.

W trakcie oglądania filmu, rodzi się odczucie, że po I wojnie światowej w Europie rozprzestrzeniał się groźny wirus, pragnienie podboju, podporządkowanie sobie słabszych (a może rozprzestrzeniał się on zza żelaznej kurtyny, gdzie szalał głód i represje?). Skutkiem działania tego „wirusa” była niesprawiedliwość, jak to widzimy na przykładzie stosunku polskich władz wobec Ukraińców. Jednak za okrucieństwo i uciskanie innych narodów przychodzi kara. 1 września 1939 roku Polska przyjęła uderzenie nazistowskich Niemiec. W końcu, po sześciu latach, zapłacić musiał i agresor - nazistowskie Niemcy.

Film Bereza Kartuska nie jest skierowany przeciwko Polsce, jedynie przypomina o doświadczeniach ukraińskich. Przypomina, że ograniczenie polityków prowadzi do tragedii narodów, którymi ci politycy rządzą. 55 minut filmu ogląda się niemal bez tchu: sam temat i materiał jest Ukraińcom prawie nieznany. Struktura filmu jest dynamiczna, wypowiedzi naocznych świadków przeplatają się z kronikami i fotografiami. Pod koniec filmu brzmią słowa: doświadczenia w Berezie Kartuskiej nie złamały, a wręcz przeciwnie, wzmocniły ducha ukraińskich patriotów.

Filmowcy dość rzadko pokazują walkę o niepodległość, zwłaszcza walkę zbrojną przeciw niemieckiemu terrorowi i działaniom partyzantki bolszewickiej na Ukrainie. W szeregach Ukraińskiej Powstańczej Armii (1943-1952) walczyli ludzie o różnych przekonaniach i dlatego ugrupowanie to miało charakter ogólnonarodowy. Poprzez swe działania armia ta wywalczyła Ukrainie pozycję na arenie międzynarodowej, ukazała światu naród ukraiński jako siłę walczącą z bolszewickim imperializmem w czasie, gdy wiele innych narodów przed nim kapitulowało.

Tragiczne wydarzenia na Wołyniu z lat 1943-1944 są w kinie niemal nieobecne. Przedstawiciele niektórych polskich partii politycznych zażądali od strony ukraińskiej uznania (z ich punktu widzenia) ludobójstwa Polaków dokonanego przez UPA na Wołyniu. W rzeczywistości bratobójcze walki pomiędzy Polakami i Ukraińcami często inspirowały i wspierały siły z zewnątrz. Ginęli starcy, kobiety i dzieci. Tragedia ta, nie w pełni zbadana przez naukowców, praktycznie nie jest obecna w kinie ukraińskim. Rany nie przestają krwawić i dziś. Znany ukraiński dokumentalista Serhij Bukowski poruszył ten temat w serialu Wojna. Ukraiński rachunek (2004, Studio 1+1) i stwierdził: „Nie można było jedynie zasygnalizować tematu stosunków ukraińsko-polskich, ponieważ konflikt ten pociągnął za sobą ofiary. Ograniczyliśmy się do niewielkiego fragmentu, ale jest to temat na odrębny film". W 2004 roku nakręcono dla telewizji dwuczęściowy film Wotyń. Znak nieszczęścia 
(2003, scenariusz i reżyseria Ołeksandr Bałaban, Ołeksandr Radynski). W obrazie tym przedstawiono wypowiedzi ocalałych Ukraińców, którzy ucierpieli podczas tragedii wołyńskiej.

Prócz radzieckich organów ścigania z ukraińskim ruchem wyzwoleńczym walczyły również władze komunistycznej Polski. Od sierpnia 1945 roku, gdy zachodnie ziemie ukraińskie (Łemkowszczyzna, Posanie, części regionów lubaczowskiego, rawskiego, sokalskiego, chełmskiego i Podlasie zamieszkiwane głównie przez ludność ukraińską) zgodnie z porozumieniami pomiędzy władzami ZSRR i PRL oddano Polsce, do USRR przymusowo wysiedlano miejscową ludność ukraińską. UPA aktywnie przeciwdziałała tym akcjom. Przeciwko ukraińskiemu podziemiu rzucono specjalnie przygotowane jednostki Wojska Polskiego, Milicji Obywatelskiej, Urzędu Bezpieczeństwa i Wojsk Straży Granicznej. Procesom deportacji towarzyszyły ciągłe walki z UPA. Przejście UPA do walki podziemnej zapobiegło jej ostatecznej klęsce. Pod koniec 1946 roku polski rząd postanowił wysiedlić na zachodnie obszary Polski tych Ukraińców, którym udało się uniknąć deportacji ${ }^{115}$. W 1947 roku totalitarne państwo polskie decyzją Biura Politycznego KC PZPR przeprowadziło czystki etniczne wobec swoich obywateli narodowości ukraińskiej, którzy zamieszkiwali południowo-wschodnią część kraju (południowe Podlasie, Chełmszczyzna, Nadsanie, Zachodnia Bojkowszczyzna i Łemkowszczyzna). Na północno-zachodnie tereny Polski wysiedlono 150 tysięcy Ukraińców, którzy mieli się tam zasymilować z miejscową ludnością. Represje otrzymały kryptonim akcja „Wisła”. Trwała ona od 28 kwietnia do 28 lipca 1947 roku. Prawie 4 tysięce Ukraińców bezpodstawnie uwięziono w obozie koncentracyjnym w Jaworznie; w wyniku tortur, przemocy, głodu i chorób zginęło tam 162 Ukraińców; działał Wojskowy Sąd Grupy Operacyjnej „Wisła”.

Właśnie o tych czasach i wydarzeniach opowiedziano w filmie Żelazna sotnia (scenariusz Wasyl Portiak, reżyser i producent Ołeś Janczuk, zdjęcia Witalij Zymoweć, muzyka Wołodymyr Hronski. Obsada: Mykoła Bokłan — setnik Hromenko, Kateryna Kisteń - Ksenia, Ihor Pisnyj — „Czumak”, Wiaczesław Wasyliuk — „Kogut”, Oleh Prymohenow — „Sowa”, Ołeksij Zubkow — „Pająk”, Dmytro Tereszczuk - Misza. Film powstał w koprodukcji Bores Homes Pty Ltd, Australia i Studia Ołeś, Ukraina, 2004). Świadkiem i uczestnikiem wydarzeń we Wschodniej Polsce była sotnia żołnierzy UPA dowodzona przez Dudę „Hromenkę”.

Film sfinansował australijski mecenas Jurij Boreć. Kanwę filmu stanowiła książka autobiograficzna UPA $w$ wirze walki, w której z wielką starannością i dokładnością opowiedziano o odwadze młodych żołnierzy. Ich imiona (pseudonimy) oraz nazwy wielu wsi i miasteczek autor książki zapamiętał; opowiedziano nie tylko o walkach ukraińskich żołnierzy, lecz także o ich życiu codziennym. Jurij Bo-

115 Протиповстанська боротьба, [w:] Украӥнська Повстанська Армія. Історія нескорених, Львів 2007, s. 304. 
reć jako młody chłopak zaciągnął się do Ukraińskiej Powstańczej Armii (jest on jednym z bohaterów książki i filmu o pseudonimie „Czumak”) do sotni Mychajły Dudy „Hromenki”. Sotnia walczyła z oddziałami odwetowymi, broniła Ukraińców, których przesiedlano w północno-zachodnie rejony Polski. W końcu, na rozkaz swoich dowódców, sotnia przekroczyła granicę i przez Czechosłowację, Austrię, dotarła do Niemiec Zachodnich. Celem tego marszu do Europy Zachodniej było opowiedzenie światu o walce Ukraińców o własne państwo. Po pobycie w obozach dla przesiedleńców Boreć wyjeżdża do Australii. Dzięki licznym talentom został jednym z czołowych organizatorów branży budowlanej w swoim mieście. Zbudował m.in. ulicę Stepana Bandery i Symona Petlury ${ }^{116}$. Był zarówno dobrym przedsiębiorcą, jak i aktywnym działaczem społeczności ukraińskiej w Australii, napisał kilka książek o UPA i swoich rodakach. Książki te trafiły na Ukrainę na początku lat 90. UPA w wirze walki to dokument, którego bohaterowie są realnymi postaciami; prawdziwe są opisane w niej wydarzenia. W filmie nie mogły zostać przedstawione wszystkie zdarzenia, ale akcja rozwija się dynamicznie, postaci żołnierzy UPA są zindywidualizowane, przedstawiono ich cechy charakterystyczne, pokazano gotowość do poświęceń, optymizm i honor. Pokazano też polskich przywódców komunistycznych, którzy decydują o przeprowadzeniu akcji „Wisła”, na czele której stanął generał Stefan Mossor. Ołeh Dracz z dużą ekspresją i dynamiką zagrał polskiego generała, upitego nie tyle alkoholem, ile raczej krwią zamordowanych przez siebie ofiar.

„Służący budowaniu jedności narodowej Ukraińców film jest jednocześnie realizacją w dość mocny sposób odbiegającą od realizmu historycznego i prezentującą dość subiektywne podejście do omawianych wydarzeń" - stwierdza Łukasz Jasina $^{117}$. Niewątpliwie, przecież film oparto na wspomnieniach konkretnej osoby będącej uczestnikiem tych wydarzeń i postrzegającej je subiektywnie.

Sceny ekstremalne przeplatały się ze wzruszającymi obrazkami spokojnego życia. Opowieść, pięknie sfilmowana przez operatora Witalija Zymowcia, jest rzadkim w kinie ukraińskim przykładem filmu przykuwającego uwagę widowni, pomagającym nieuprzedzonemu widzowi wyrwać się z sieci kłamstwa. Obraz z powodzeniem był wyświetlany w kinach, zdobył nagrody na dwóch ukraińskich festiwalach filmowych (w Jałcie i Berdiańsku), gdzie był wyróżniany przez widownię.

Badania naukowe prowadzone w czasach niepodległej Ukrainy przez historyków, pisarzy i filmowców, mające na celu wyświetlenie prawdy o działalności OUN i UPA od 2010 roku, wraz z dojściem do władzy na Ukrainie Partii Regionów, wstrzymano na szczeblu oficjalnym. Na tych, którzy walczyli i ginęli za wolność Ukrainy, rozpoczęła się neobolszewicka nagonka i przyklejanie im etykiet „faszystów”, „,nazistów” i in. „Walka z faszyzmem” stała się ulubionym zajęciem człon-

116 В. Кук, Переднє слово, [w:] Ю. Борець, УПА у вирі боротьби. Спогади учасника повстанської боротьби (1941-1948), Київ 2004.

117 Ł. Jasina, op. cit. 
ków ukraińskiego parlamentu wywodzących się z komunistów i członków partii rządzącej. Propaganda ta rodziła się w Moskwie i była ukierunkowana na tych, którzy nie znają i nie chcą poznać prawdziwej historii, na ludzi wychowanych na wygodnej do przełknięcia propagandzie. Po Majdanie i rewolucji godności Ukraińcy ponownie zwracają się ku przeszłości, by przekonać się, na jakiej fałszywej propagandzie bazowała władza radziecka. Teraz przekształciła się ona w politykę i imperialne ambicje Kremla, by przywrócić „niepokornych” sąsiadów w granice „nierozerwalnego związku”. Jednak nie wszyscy Ukraińcy, nawet na wschodniej Ukrainie, marzą o rosyjskim „raju”.

Podsumowując nasze badania, należy zwrócić uwagę na jeszcze jednen aspekt obecności Polski w kinie ukraińskim, a mianowicie twórczą współpracę. Wspomniano już o filmie dokumentalnym Bliscy a dalecy. Jednak najbardziej konsekwentny był tu Jerzy Hoffman. Zatrudnił on aktorów ukraińskich w filmie Ogniem i mieczem, a rolę Bohdana Chmielnickiego genialnie zagrał ukraiński aktor Bohdan Stupka. Hoffman nakręcił wielkie dzieło: czteroodcinkowy film dokumentalny Ukraina - narodziny narodu. Powstało również kilka wspólnych ukraińsko-polskich filmów fabularnych. Jednym z najbardziej znanych jest film Serce na dłoni Krzysztofa Zanussiego z Bohdanem Stupką w roli głównej (nagroda za najlepszą rolę męską na Międzynarodowym Festiwalu Filmowym w Rzymie). W szkole Krzysztofa Zanussiego, w szkole Andrzeja Wajdy i Łódzkiej Szkole Filmowej uczą się młodzi ukraińscy filmowcy. Przykładem współpracy między oboma krajami jest absolwent Andrzeja Wajdy, lwowianin Ołeksandr Denysenko pracujący nad adaptacją opowiadania Marii Matios Stodka Darusia. To wspólna produkcja polsko-ukraińska, a mistrz polskiego i światowego kina Andrzej Wajda zlecił tę pracę debiutantowi (wiosną 2015 roku w Kijowie odbyła się premiera teasera filmu).

Ukraina i Polska mają za sobą wieki wspólnej historii, warto znać te doświadczenia i wyciągnąć wnioski z przeszłości. Rodzi to nadzieję, że przyjaźń i wzajemne wsparcie obu krajów będą opierać się na solidnych fundamentach.

Ttumaczenie z j. ukraińskiego Przemysław Jóźwikiewicz

\title{
POLAND IN UKRAINIAN CINEMA
}

\author{
Summary
}

Multinational Ukraine in the time of Ukrainization conducted a policy which was supportive of the national identity, allowed the possibility of the cultural development of, among others, Jews, Crimean Tatars, and Poles. Cinema was exemplary of such policy, in 1925 through to the 1930s a number of films on Jewish and Crimean Tatar topics were released by Odessa and Yalta Film Studios. However, the Polish topic, which enjoyed most attention, was heavily politicized due to tensions between the USSR and the Second Commonwealth of Poland; the Soviet government could not forgive Poland the refusal to follow the Bolshevik path. The Polish topic was particularly painful for the Ukrainian 
Soviet Socialist Republic due to the fact that the Western fringe of Ukrainian lands became a part of Poland according to the Treaty of Riga which was signed between Poland and Soviet Russia. This explains why Polish society was constantly denounced in the Ukrainian Soviet films (The Shadows of Belvedere, 1927, Behind the Wall, 1928). Particular propagandistic significance in this case was allotted to the film PKP (Piłsudski Kupyv Petliuru, Piłsudski Bought Petliura, 1926), which showed Poland subverting the stability of the Ukrainian SSR and reconstructed the episode of joint battles of Ukrainians and Poles against the Bolsheviks in the summer of 1920 as well as the Winter Campaign. The episodes of Ukrainian history were also shown on the screen during this favorable for cinema time, particularly in films Zvenyhora (1927) by Oleksandr Dovzhenko and a historical epopee Taras Triasylo (1927). The 1930s totalitarian cinema presented human being as an ideological construct. Dovzhenko strived to oppose this tendency in Shchors (1939) where head of the division Mykola Shchors is shown as a successor of Ivan Bohun, specifically in the scene set in the castle in which he fights with Polish warriors. Dovzhenko was also assigned by Soviet power to document the events of the autumn of 1939, when Soviet troops invaded Poland and annexed Western Ukraine. The episodes of "popular dedications" such as demonstrations, meetings, and elections constituted his journalistic documentary film Liberation (1940). A Russian filmmaker Abram Room while working in Kyiv Film Studios on the film Wind from the East (1941) did not spare on dark tones to denunciate Polish "exploiters" impersonated by countess Janina Pszezynska in her relation to Ukrainian peasant Khoma Habrys. Ihor Savchenko interpreted events of the 17th century according to the topic of that time in his historical film Bohdan Khmelnitsky (1941) where Poles and their acolytes were depicted as cruel and irreconcilable enemies of Ukrainian people both in terms of story and visual language, so that the national liberation war lead by Khmelnytsky appeared as a revenge against the oppressors. The Polish topic virtually disappeared from Ukrainian cinema from the post-war time up until the collapse of the Soviet Union. The minor exclusions from this tendency are Zigmund Klossovsky, a film about a brave Polish secret service agent shot during the evacuation in 1945 and the later time adaptations of the theatre pieces The Morality of Mrs Dulska (1956) and Cracovians and Highlanders (1976). Filmmakers were able to return to the common Polish-Ukrainian history during the time of independence despite the economic decline of film production. A historical film Bohdan Zinoviy Khmelnitsky by Mykola Mashchenko was released in 2008. It follows the line of interpretation given to Khmelnitsky's struggle with Polish powers by Norman Davies, according to whom the cause of this appraisal was the peasant fury combined with the actual social, political and religious injustices to Eastern provinces. The film shows how Khmelnitsky was able to win the battles but failed to govern and protect the independence of Hetmanate which he had founded. The tragedies experienced by Poland and Ukraine during the Second World War were shown in a feature film Iron Hundred (2004) by Oles Yanchuk based on the memoirs of Yuri Borets UPA in a Swirl of Struggle as well as in documentaries Bereza Kartuzka (2007), Volyn. The Sign of Disaster (2003) among others.

Translated by Larisa Briuchowecka 